\title{
産婦人科疾患
}

\section{1 分婏後腟壁血腫に対する処置について}

$\begin{array}{clllll}\text { 秋田 湖東総合病院 } & \text { 産婦人科 } & \text { 村田 } & \text { 誠 } & \\ & & & \\ & & \text { 竹内 } & \text { 譲 } & \text { 蒔田 光郎 } \\ \text { 同 } & \text { 臨床検查科 } & \text { 伊藤 } & \text { 朝夫 } & & \end{array}$

はじめに

分婏後胵壁血腫は、時に血腫表面が破綻し、そこょりの出血に対し処置に窮するてと がある。すなわち、解剖学的に血腫周囲は軟部組織であり、圧迫止血が困難であること、 また、縫合操作を試みても周囲組織が血腫により浮腫状で、あろくなって扔り有効な縫 合が困難であるてとから大量出血につながる場合がある。我々は、今回、 $20,000 \mathrm{ml}$ にあ拉 よぶ輸血のすえに救命しえた一例を経験し、その一例を含み、当科および当科関連大学 病院である秋田大学での症例む含め、分婏後血腫例につき、典型的 4 症例をまとめ、検 討を加えたので報告する。

\section{症例 1. T.T 29才 $\bigcirc$ 妊 $\bigcirc$ 産}

\section{家㵀歴}

既往歴 $>$ 特記事項なし

現病歴妊娠 40 週前期破水で入院。オキシトシン点滴静注により分娩誘発。3,300 g

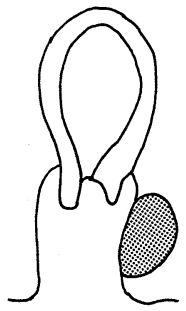
女览を自然分婏。分婏時出血量 $500 \mathrm{~g}$ 。分婏 30 分後殿部痛 あり。左側臸壁に下図の様な血腫形成あり。破綻していず、 外出血を認めず、また、血腫の増大傾向もなく、疼痛に対 し、対症的に対応するのみで経過観察し、約 1 ケ月後、切 開、血腫内容を排出し、ドレナージした。

症例 2. M.K 28才 $\bigcirc$ 妊 $\bigcirc$ 産

家族歴父胃癌 (胃切除)

既往歴 18 才乳腺線維腫

現病歴妊娠 39 週 陣痛発来で入院。3,800 g 男児を自然分娩。分婏時出血量 125

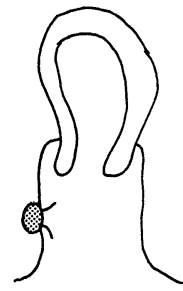

$g$ 。分婏約 5 時間後、弛緩出血で $700 \mathrm{~g}$ の凝血塊排出。ま た、右胵壁に、左図のように母指頭大の血腫形成あり。血 腫表面に小亀裂あり、そこょり小動脈性に出血あり。ガー ゼタンポン、用手により圧迫止血を行う。総出血量は弛緩 出血による出血が中心であるが $1,800 g$ 。結果的に圧迫止 血により止血された。

\section{症例 3. Y.S 26才 C妊 ○産}

家族歴 既往歴 
現病歴妊娠 37 週 吸引分娩 $2,800 \mathrm{~g}$ 男児。分娩後、弛緩出血打よび下図、右側 深部腔壁裂傷あり。子宮収縮剤、裂傷部縫合で一時的に止血す。しかし、

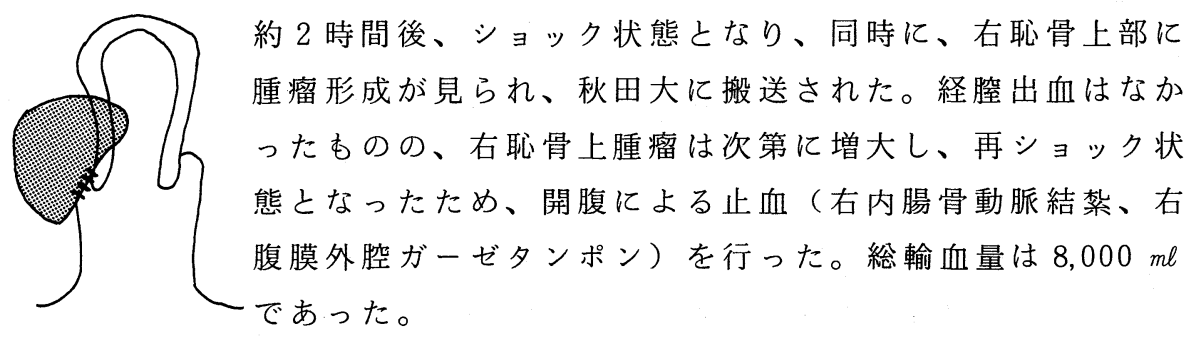

術後、2 日にガーゼタンポンを抜去した。

\section{症例 4. T.M 24才 $\bigcirc$ 妊 $\bigcirc$ 産}

家族歴

既往歴

現病歴妊娠 40 週 自然分娩 $2,650 \mathrm{~g}$ 女児、分婏時出血量 $55 \mathrm{~g}$ 。1 時間半後、外陰 部異和感あり。右胵壁深部に血腫形成、表面が破綻し、持続出血あり、 ガーゼタンポンを行うあ止血せず、当科紹介入院となった。入院時、血

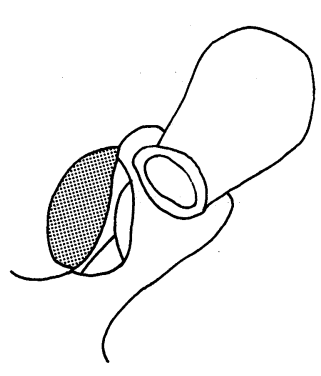
圧80、下図の如く、裂傷あり。縫合、ガーゼタンポンを行 い、一時的に止血された。しかし、約 3 時間後より、持続的 出血あり、再びショック状態となった。血沈を測定したと ころ、15分值 $1 \mathrm{~mm}$ と遅述し、D I C が疑われ、メシル酸が ベキサート持続点滴を開始した。輸血を新鮮血とし、胵 壁再縫合を施行したが、子宮内よりの出血も認められ、収 縮不良となり、子宮収縮を試みるあ効果なく、止むなく、 子宮全摘術を施行、さらに、血腫裂傷部をガーゼタンポンにより圧迫し た。しかし、その後も持続的に出血を認めたため、秋田大に搬送した。 その時点までの輸血量は $13,000 \mathrm{ml}$ によんだ。大学搬送後、結局、血腫 内にオキセルガーゼを充てんし、その上よりガーゼタンポン、更に、用手 で約 3 時間圧迫した。また、抗 D I C 療法としてアンチトロンビン製剤 を 3,000 I U 、フィブリノゲン $3 g$ 、扰よび新鮮血輸血を行ったとてろ、 次第に、出血量が減少し、止血された。

結 論

症例 1 のように比較的軽症で済むあのから、症例 3,4 のように、出血死にも連がりか ねない症例屯、まれではあるが見られる。我々の経験した、タイプの違う4 症例を呈示 し、止血に至る経過を報告した。結果的に血腫破綻のない症例 1 では自然観察、他の 3 例では、圧迫止血で止血され、縫合は無効であった。 
502 当科不妊症外来における現況

$\begin{array}{rrrrr}\text { 新田 } & \text { 豊 } & \text { 長 屋 } & \text { 寿雄（山口県厚生連小郡第一総合病院） } \\ \text { 上田 } & \text { 一之 } & \text { 田村 } & \text { 晴代 } & \text { 竹島 信 宏 } \\ & & & & \text { (山口大学医学部産婦人科教室） }\end{array}$

（はじめに）私達は今回、過去 3 年間に当科不妊症外来を受診した患者 にっいて、不妊原因、妊娠率、治療内容等、種々の検討を加えたので、報 告する。

（対象及び方法） 対象は、昭和 59 年 1 月から昭和 61 年 12 月までに、当科 不妊症外来を受診した 134 例とした。不妊原因の診断については、初診後 ただちに基礎体温の測定を開始し、卵胞期初期に血中 LH、F S 、エストラ ジオール及びプロラクチンレベルの測定、LH-RH テスト、メトクロプロ ミドテストの実施を行い、内分泌因子を調べる。卵胞期中期に、ルビンテ ス卜、子宮卵管造影法を行い、子宮卵管因子を調べる。卵胞期後期には、 性交後試験を行い、男性因子及び頸管粘液因子の検索を行う。また、必要 に応じて、泌尿器科に扔いて精查を行う。排卵後は、黄体プロゲスチロン レベル測定を行い、黄体機能を調べる。卵胞発育は、卵胞期の超音波検查、 尿中エストロゲン測定、頸管粘液検查にて、モニタリングを行う。

（結果）表 1 は、昭和 59 年 1 月から 昭和 61 年 12 月までの 3 年間に、当科不 妊症外来を初診した患者数を示す。乙 の期間の外来初診患者数に占める不妊 症患者の割合は、 $2.7 \%$ あった。ま た、約 6 割の患者が原発性不妊症であ った。図1 1 、初診時における不妊期 間の分布を示している。1〜2年と、 3 年以上の 2 力所にピークがある。

$1 \sim 2$ 年の群では、原発例 $=18$ 例之 続 発例 $=13$ 例より多いが、 3 年以上の 群では、原発/続発 $=22 / 21$ とぼ同 数であった。諸家の報告では、1〜2 年の群では原発例が多く、3 年以上の 群では、続発例が多いとされて打り、 この結果と食い違う。

表 2 には、不妊原因別患者数を示し ている。不妊原因が重複している場合 は、各原因に加えたため総計は実数よ りも多くなっている。不妊原因として

\section{表 1 当科における年次別不妊症患者数}

\begin{tabular}{|c|c|c|c|}
\hline & 原 発 性 & 続 発 性 & 総 数 \\
\hline 昭和59年 & 30 & 24 & 54 \\
\hline 昭和 60 年 & 25 & 17 & 42 \\
\hline 昭和 61 年 & 24 & 14 & 38 \\
\hline 計 & $\begin{array}{c}79 \\
(59.0 \%)\end{array}$ & $\begin{array}{c}55 \\
(41.0 \%)\end{array}$ & 134 例 \\
\hline
\end{tabular}

3 年間の患者数の総患者数に占める割合 134 例 $/ 4,908$ 例 $=2.7 \%$

図 1 初診時における不妊期間

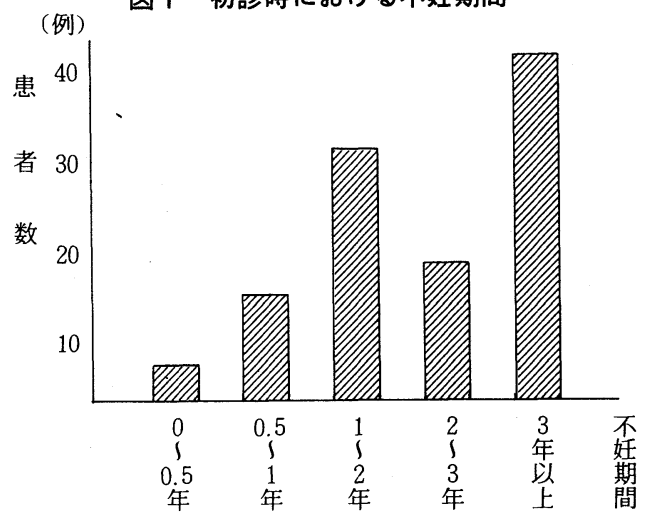


は、内分泌因子が最も多く、次いで、男 性因子、子宮卵管因子の順であった。乙 れは、不妊原因が、子宮卵管因子、内分 泌因子、男性因子の順に多い亡する諸家 の報告と異なる。

図2 は、初診から妊娠成立までの治療 期間の分布を示す。 33 例、70\%が 1 年以 内に妊娠しており、そのうち 23 例 $48.9 \%$ は 6 力 月内の妊娠であった。

表 3 には、不妊原因別妊娠率を示す。 こてでは内分泌因子のうち、遅発排卵、 黄体機能不全、高プロラクチン血症並び にその関連疾患等の、軽症排卵障害例の 妊娠率が高いてとがわかる。

表 4 では、妊娠に成功した周期に用い た治療法を示している。表 2 で示したよ うに、内分泌因子のうち、遅発排卵及び 黄体機能不全が多いてとから、経口排卵 誘発剂クロミッドの使用が目立つ。

表 5 では、妊娠成立例の妊娠の転㷌を 示している。流産、子宮外妊娠、子宮内 胎児死亡率を合わせても、全体の $17 \%$ を 占めるにとどまり、通常の妊娠統計にお ける率と有意差はなかった。分婏方法の 内訳は、経胵分婏例 25 例、帝王切開例 4 例であり、帝王切開率は約 $14 \%$ を示した。 （終わりに）以上、当科不妊症外来に 扣ける過去 3 年間の患者について、検討 を行った。そのうち、当科に打ける不妊 原因では、内分泌因子が最む多い点が特 徴と言える。

近年、新しい精子洗浄濃縮法として、 Percoll 法が注目されており、当科に打 いても、最近導入している。 3 年以上の 不妊例において、本法による妊娠成立を 得ており、妊娠率の改善が期待される。

今後、症例を加えて検討を行っていき たい。
表 2 不妊原因別患者数

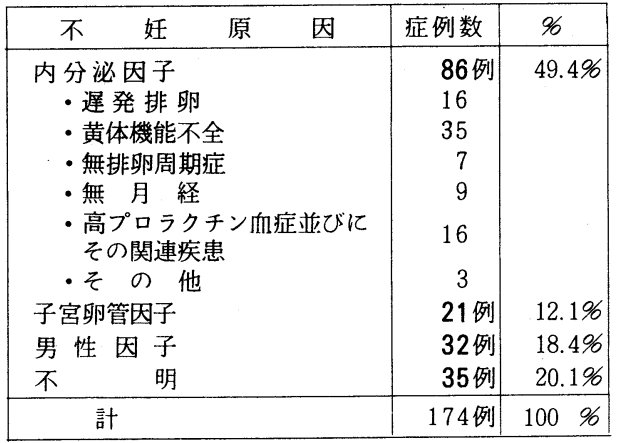

図 2 初診から妊娠に至るまでの治療期間

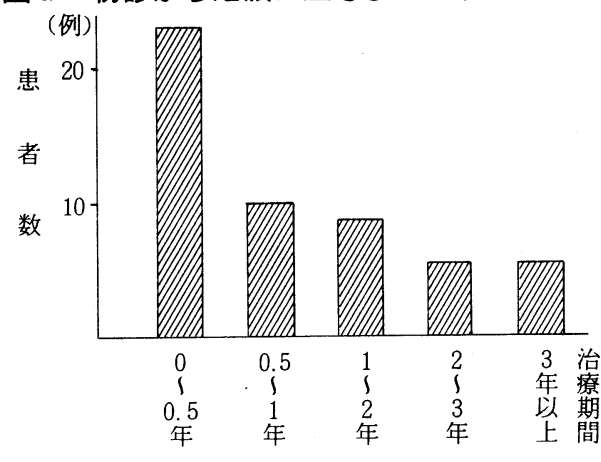

妊娠率 $=47$ 例 $/ 134$ 例 $(35.1 \%)$

表 3 不妊原因別妊娠率

\begin{tabular}{|c|c|c|c|c|}
\hline 不 & 妊 & 原 & 症例数 & $\%$ \\
\hline \multirow{7}{*}{\multicolumn{3}{|c|}{$\begin{array}{l}\text { 内 分泌 因子 } \\
\text { ・遅 発 排 卵 } \\
\text { • 黄体機能不全 } \\
\text { • 無排卵周期症 } \\
\text { • 無 月 経 } \\
\text { ・高プロラクチン血症並びに } \\
\text { その関連疾患 } \\
\text { ・その 他 }\end{array}$}} & 34例 & $53.1 \%$ \\
\hline & & & 6 & \\
\hline & & & 15 & \\
\hline & & & 3 & \\
\hline & & & 2 & \\
\hline & & & 7 & \\
\hline & & & 1 & \\
\hline \multicolumn{3}{|c|}{ 子宮卵管因子 } & 10例 & $15.6 \%$ \\
\hline \multicolumn{3}{|c|}{ 男性因子 } & 9例 & $14.5 \%$ \\
\hline \multicolumn{3}{|c|}{ 不明 } & 11例 & $17.2 \%$ \\
\hline \multicolumn{3}{|c|}{ 計 } & 64 例 & $100 \%$ \\
\hline
\end{tabular}

表 4 妊娠周期の治療内容

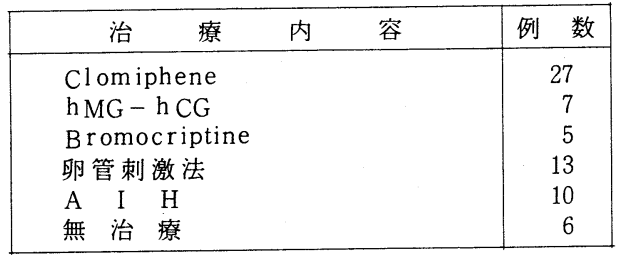

表 5 妊娠例の転㷌

\begin{tabular}{|c|c|c|c|c|}
\hline 妊 & 娠 & の 転 & 州 & 例 数 \\
\hline 分 & 婏 & & & 29 \\
\hline 経 過 & 中 & & & 9 \\
\hline & 産 & & & 5 \\
\hline & 妊 & & & 1 \\
\hline 子宮内 & 台児死 & & & 2 \\
\hline 不 & 明 & & & 1 \\
\hline
\end{tabular}


○潤田嘉朗, 富田昭, 中川国四, 一宮和夫,

山本英豊, 清水康史,

(総合病院土浦協同病院産婦人科)

〔はじめに〕周産期管理に扔いて母体搬送は次第に重要な 位置を占めてきているが, 現状に拈いては種々の問題を含 んでいる。県南地方の唯一の N I C U 施設のある当病院に打 ける母体搬送の実態の解析と, 当院での周産期死亡との関 連について報告する。

〔対象〕昭和 59 年より 61 年までの，20医院及び 6 病院， 計 26 施設からの妊娠 24 週以降の母体搬送 111 件, .116 出産児

妊娠24週以降 母体搬送件数

\begin{tabular}{|c|c|}
\hline 年 度 & 件 数 \\
\hline 59 年 & $31 \quad(0)$ \\
\hline 60 年 & $40 \quad(4)$ \\
\hline 61 年 & $40 \quad(1)$ \\
\hline 合計 & 111 (5) \\
\hline
\end{tabular}

表一 1

\section{(双胎：5）。（表-1）}

妊娠 24 週以降，母体搬送疾患名

〔結果〕搬送例中，母体適応飞よるあのと，胎 児適応によるものとの区別はむづかしいが，圧倒 的に胎児救命を目的としたあのが多かった。搬送 時週数は平均 34.3 週で，分婏時週数は平均 35.3 週， 搬送疾患名は, 前期破水, 前置胎盤及び妊娠中毒 症で約半数以上を占めていた。（表一2）

搬送分娩児 116 名中，NICU 入院児は59名(53\%) と約半数で, 初期より当院管理分婏児の $8.7 \%$ と 比らべると, 搬送症例には当然かむ知れないが, 八イリスク症例が極めて多い。(表-3)

又搬送出産児の予後は，95名(83\%)生存例で， 21 名 (17\%) が周産期死亡例であり，59名の NICU

\begin{tabular}{|c|c|}
\hline 疾患名 & 件 数 \\
\hline \hline 前期破水 & $21(1)$ \\
\hline 前置胎盤 & $19(2)$ \\
\hline 娃桭中串症 & $17(3)$ \\
\hline 切迫早産 & $12(1)$ \\
\hline 胎盤早期 & $7(6)$ \\
\hline 前回帝切 & 6 \\
\hline C.P.D. & 6 \\
\hline 分婏㩧延 & 6 \\
\hline
\end{tabular}
(昭和59年 $\sim 61$ 年) 入院新生児の予後は本学会 No. 413 の演題 で小児科より別に発表する。

出産新生児体重をみると, 分婏時週数 の平均が 35.3 週からわかるように $2500 \mathrm{~g}$ 以下の未熟児が 62 名と多く, $1000 \mathrm{~g}$ 以下 の極小未熟児む 9 名中 5 名生存となって いる。周産期死亡児体重をみると，体重 の少ないほどその率は高くなっているが, 数としては, 各体重セクションとあ著しい 娃娠24週以降, 未熟児センター入院新生児数 差はないょうである。（表一 4 )

\begin{tabular}{|c|c|c|c|c|}
\hline \multirow{2}{*}{$\begin{array}{r}\text { 項目 } \\
\text { 年度 }\end{array}$} & \multicolumn{2}{|c|}{ 当 院 例 } & \multicolumn{2}{|c|}{ 搬 送 例 } \\
\hline & 分 婏 数 & 七ン多 & 分 娩 数 & 七ン院数 \\
\hline 59 年 & 934 & 92 & 31 & 16 \\
\hline 60 年 & 874 & 85 & 40 & 24 \\
\hline 61 年 & 796 & 49 & 40 & 19 \\
\hline 合 計 & 2604 & $\begin{array}{c}226 \\
(8.7 \%) \\
\end{array}$ & 111 & $\begin{array}{c}59 \\
(53 \%)\end{array}$ \\
\hline
\end{tabular}

表 -3

搬送例の分婏様式は，111例中 44 例 (40\%) が緊急帝切例で，その中 37 例が生存例だが，4例が帝切後早期新生児死亡例，3例が帝切死産例で， その大部分が胎盤早期剥離の母体適応としての帝切例であった。 
次に，周産期死亡例 の原因疾患 を，当院例と比較しながら検討す る。（表一 5 ）をみる之, 当院例は 分娩数 2604 例中，24 例，搬送例 は分娩 111 例中, 20 例之, 率は圧 倒的に後者に多いのであるが, 疾 患名から考察すると, 数としては 夫っの疾患の両者間で著しい差はな いょうである。特に胎盤早期剥離 例は診断時，両者とあほとんどが 子宮内胎児死亡例で，搬送例中救命し得たの は 1 例のみであった。前置胎盤, 前期破水, 合併症及び胎位異常による死亡例は, 当院例 では，ないととからみると，搬送の時期が早 ければ搬送例であ救命し得たかあ知れない。 （表一6）は，24週以降の周産期死亡数をグラ フでみたものであるが，59年度を除き搬送例 が半数以上占めている。59 年度の当院例には, 重症奇形児死亡例之重症妊娠中毒症（以下妊 中と呼ぶ）の子宮内胎児死亡例が特飞多い年 度であつたためである。

〔考案〕1) 受入れ側の問題点として, 当院の N I CUベット数あ制限があり, 県レベルでNICU 施設機関の増設が焦眉の急であろう。2）搬送 者側への問題点として, 搬送の時期, タイミング を誤らない事，それには 管理体制の充実が必要だ が，特に前期破水，妊中 及び胎児仮死については その感が強い。胎盤早期 剥離にっいては, 現在で は早期発見が困難だけに 母体適応としての緊急性 を先づ念頭に打かねばな

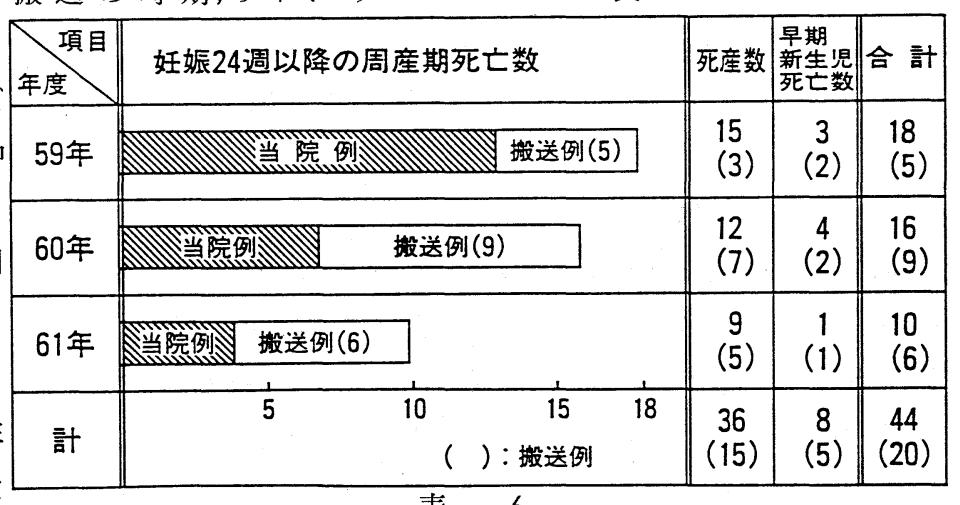
らない。〔まとめ〕1) 当院の周産期死亡率は母体搬送例の状況によって 著しく左右されている。2）前期破水，妊中，胎児仮死例は搬送のタイミング 及び時期が誤らなければ，充分に救命し得る。つまり，母体搬送は疾患に より予後が大きく左右されるから，救命救急と長期集中管理可能疾患とを 区別して搬送のタイミングを検討する事が必要であると考える。
（昭和59年～61年）

$$
\text { 表 }-4
$$

妊娠24週以降周産期死亡原因疾患 (昭和59年～61年)

\begin{tabular}{|c|c|c|c|}
\hline 疾患名 項 目 & 当院例 & 搬送例 & 合 計 \\
\hline 胎盤早期制離 & $5(4)$ & $6(5)$ & $11(9)$ \\
\hline 奇 形（重症） & 7 & 1 & 8 \\
\hline 娃 娠 中 贵 症 & $4(3)$ & $3(1)$ & $7(4)$ \\
\hline 腈 率 異 常 & 3 & $1(1)$ & $4(1)$ \\
\hline 胎盤機能不全症 & $3(1)$ & $1(1)$ & $4(2)$ \\
\hline 不 & $2(2)$ & $1(1)$ & $3(3)$ \\
\hline 前 倍 胎 盤 & 0 & 2 & 2 \\
\hline 前期破水（超未焦児） & 0 & $2(2)$ & $2(2)$ \\
\hline 合＼cjkstart併 & 0 & 2 & 2 \\
\hline 胎 位 異 常 & 0 & $1(1)$ & $1(1)$ \\
\hline 合 & $24(10)$ & 20(12) & $44(22)$ \\
\hline
\end{tabular}

( )：子宮内胎児死亡例 表 -5 
$\bigcirc$ 四ッ谷美恵子, 関野正江, 鹿島陽子, 松本美代子 江幡世利子

( 総合病院土浦協同病院産婦人科外来)

はじめに

当院以外では，集検で要精検となった者，及び一般外来受診者を対象に 癌検診を行っているが，かなりの高率で疑陽性者が，発見されている。子 宮癌については, 早期治療を行う事により, 高い治癒率を得る事ができる。 当外来に於ても疑陽性以上の者についての対応が，予後を大きく左右する 為, 定期的な受診及び経過観察の指導を行っている。しかし中には，未受 診あ多く見られる。そこで, 当外来に於て過去 6 年間の子宮頸部癌検診者 の中から, 疑陽性以上について, その後の受診行動についての追跡調查を 行った。その結果について, 分析しまとめたので報告する。

\section{1 . 対象亡方法}

対象：過去 6 年間に当院で, 子宮頸部癌検查を受け疑陽性あるいは陽性 と診断された者 515 名

方法：外来受診カルテより分析

内容: 1. 疑陽性, 陽性診断後の受診の有無 2. 疑陽性以上の年令別比較 3. 疑陽性以上の未受診者年令別比較 4. 受診者の治療状況 5. 未受診者の居住地と職業

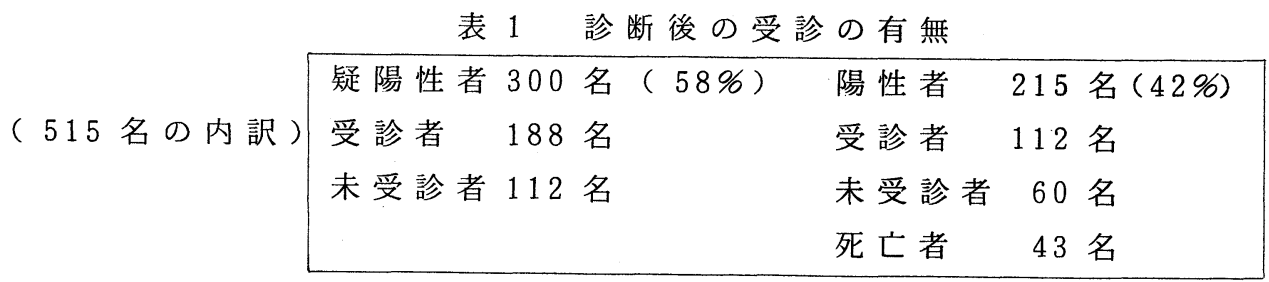

\section{2 . 結 果}

調查対象者 515 名の年令別比較については 図1 の通りである。乙の内訳をみると疑陽性 者では, 30 才 50 才代がピークで, その差は みられない。30才代は, 陽性者の 2 倍以上に 相当する。陽性者では，40才〜 60 才代がピー クを示し閉経後に患者数が多い傾向にある。

次に疑陽性以上の診断を受けた者について, 未受診者の数之年令別に比較したあのを図 2 に示す。未受診者は, 515 名中 172 名である。 内訳は特に疑陽性者が 300 名中 112 名と多く

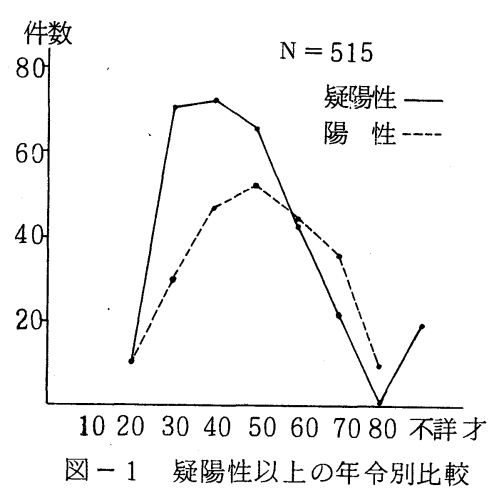


みられる。疑陽性者を年令別にみると 30 才代で, 件数 急増し40才代がピークである。陽性者では, 3030 才〜 70 才代まで増加傾向にありその差はみられ 20 ない。

次に受診者の治療状況について述べたあのが, 図 3 である。疑陽性では, 手術が $20 \%$ を示し経 過観察中が $80 \%$ とっている。しかし，陽性で は, $100 \%$ が治療の適応となっておりその殆ん どが手術の対象で（70\%）残りは放射線治療と なっている。( $30 \%)$

次に未受診者の居住地之職業について述べた あのが図 4 である。職業による内訳ではその殆 んごが，主婦（80\%）で主に農業従事である。 居住地については, 病院の通院時間を考慮し調 查した結果, 自家用車による病院迄の所要時間 では, 1 時間以上の者が 56 名, 30 分 60 分まで が 84 名みられた。

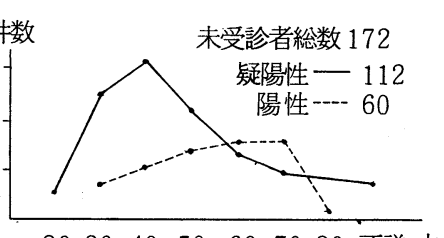

$\begin{array}{lllllll}20 & 30 & 40 & 50 & 60 & 70 & 80\end{array}$ 不詳才 困-2 未受診者の年令別比較

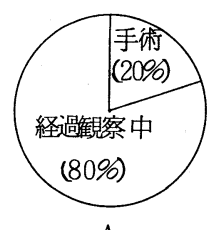

$\mathrm{A}$

疑陽性 $\mathrm{N}=188$ 陽性 $\mathrm{N}=112$

目 - - 3 受診者の治療状況

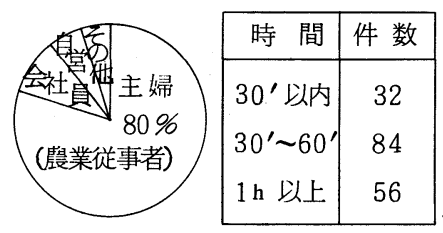

図-4 未受診者の居住地と職業

\section{3. 考 察}

子宮頸癌の平均年令は, 50 才前後であるが最近では, 若年化する傾向に あり，30才からは，定期的検查が必要である。分析結果から未受診者の疑 陽性者が 30 才代から急増しているのに反して, 受診率が低い原因は, 出産 後の育児と子供の教育の忙しさ，40才50才代では，一家の担い手と農業に 従事している為で，身体的，時間的に余裕がないと思われる。60才代から は，高年令という事で公共の交通機関にたよる為，外来通院に不便をきた している事があげられる。また, 土浦市の隣接地区は, 農村地区であり専 業農家が多く未受診者の職業であトップとなっている。そして同市は, 茨 城県の県南地域に属し未受診者の殆んどが病院を受診するのに, 1 時間前 後の時間を費やす距離から来院している事がわかった。また，疑陽性者の 治療状況からあ手術の割合が $20 \%$ と高く，いかに経過観察が重要であるか がわかる。陽性者の多くは，継続的な外来受診と共に悪化防止にむけての 自己管理が必要である。以上の事から健康教育の働きかけと各施設あるい は，市町村での集団検診の利用と追跡むれのない管理体制を確立する事の 3 点が重要であると考える。

おわりに

当外来では, 現在癌検施行後疑陽性とわかり次第電話連絡で, 来院する 事を勧めなぜ経過観察が必要であるかを指導している。また，次回来院日 の予定を記載したパンフレットを手渡し未受診者の防止に努めている。 
秋田県厚生連子宮癌検讋研究班

○蒔田光郎, 細田恒, 深谷孝夫, 村田絈治, 藤丸純一 水上端, 曾我賢次, 秋山康夫, 斉藤正信, 菅谷彪

く諸䓂〉老人保健法による子宮癌検診が施行されている今日，更め て子宮癌蚞診の精度管理とより充実した娭診内容が求められている。今回 昭和 59 年度から昭和 61 年度迄の3 年の娭診成績及び一次検診時に全受診 者を詨象に実施している内診所見について成績をまとめ子宮体癌検診につ いても言及する。

<椾診成績> ( S 59-61年)

a) 一次検診 (細胞診)

1. 受㟝者総数 66,479 名（初回受診者数 15,796名）

2.クラス分類 パパニコロ

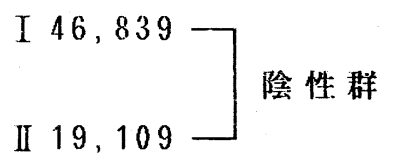

$\left.\begin{array}{cc}* \text { III } & 506 \\ \text { IV } & 15 \\ \text { V } & 10\end{array}\right]$ 要精検群 $531(169) 0.79 \%$

(*III：III $\mathrm{a}$, III , III $\mathrm{b}$ 含む)

3. 要精模率（3\%年平均） $0.79 \%$

4. 要精娭率の年度別推移

$$
\text { (表-1) }
$$

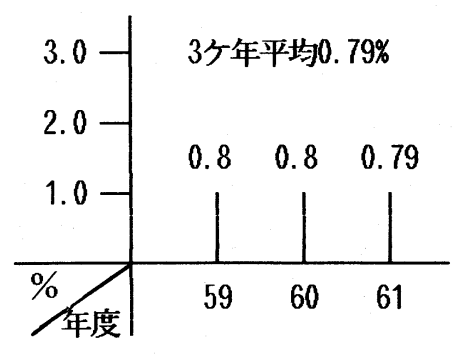

（表-1）

5.受診対象に対す当受診率

$$
\text { 住× 17\%(30才以上) }
$$

b) 二次検䧐（コルポ診，組織診）

1. 要精娭者の精㛟受䇏率

$$
\text { （3分年平均） } 96.2 \%
$$

2 . 要精検者の精㛟受診率の 年度別推移

$$
\text { （表-2） }
$$

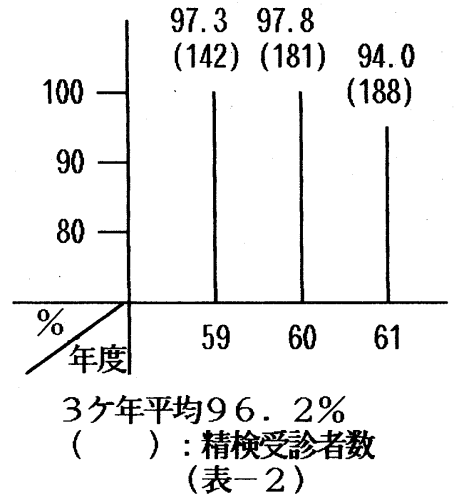




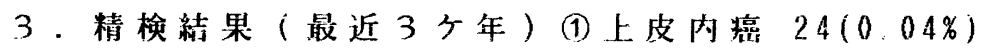

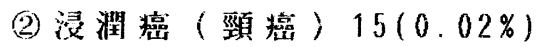

4. 癌発見の年度推移と年令分布

(1)上皮内䍃

\begin{tabular}{|c|c|c|c|c|}
\hline 年代 & 59 & 60 & 61 & 計 \\
\hline $30 \downarrow$ & 2 & & $3(2)$ & $5(2)$ \\
\hline 40 & $5(1)$ & 2 & $7(4)$ & $14(5)$ \\
\hline 50 & 1 & & 0 & 1 \\
\hline $60 \uparrow$ & $2(1)$ & 1 & $1(1)$ & $4(2)$ \\
\hline 計 & $10(2)$ & 3 & $11(7)$ & $\begin{array}{c}24(9) \\
\text { 疑1 含む }\end{array}$ \\
\hline
\end{tabular}

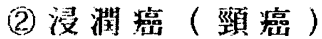

\begin{tabular}{|c|c|c|c|c|}
\hline 年代年度 & 59 & 60 & 61 & 計 \\
\hline $30 \downarrow$ & & & $2(2)$ & $2(2)$ \\
\hline 40 & & 4 & 1 & 5 \\
\hline 50 & $1(1)$ & 1 & & $2(1)$ \\
\hline $60 \uparrow$ & $2(1)$ & 2 & $2(1)$ & $6(2)$ \\
\hline 計 & $3(2)$ & 7 & $5(3)$ & $15(5)$ \\
\hline \multicolumn{5}{|c|}{ ( ) : 初回受診者数 } \\
\hline
\end{tabular}

C）（1） 2 年間の受診者10,885名中，内診上要注意者と認女られた者は 704 名 $(6.5 \%)$ であた。

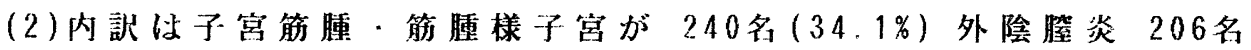
(29.3\%)，頸管ポリ-プ 130 名 $(18.5 \%)$ ，その他 90 名 $(12.8 \%)$ ，

卵巣腫瘍 29名(4.1\%)，子宮脱11名(1.6\%)の順となっている。

(3)琶注意者中，約 $70 \%$ が専門医による治燎を受けた。

く子宮体癌検診に向けて>

本年度より老人保健法新 5 ケ年計两が施行されている。秋田県厚生連 でも、いわゆるハイリスク者；すなわち最近6ケ月以内に不正出血のあ る者で（1）年令50才以上の者（2）閉経以後の者 (3)未産婦でめつて月経 不規勋の者（4)医師が必要と認める場合に実施した。現在のところ受渗

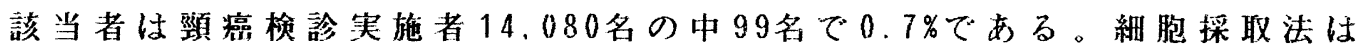
エンドサイトによる摖過細胞診とした。

<考按〉

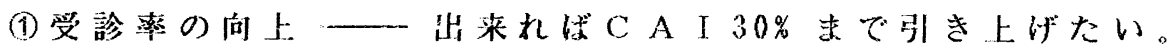

(2)要精検率に関しては，3年平均0.79\%であり，これはけイトスクリ一 ナーの充実と平行している。

(3)精検受診率に関しては，現在，平均 $96.2 \%$ の值を得ている。

(4)上皮内癌発見に関しては：ご年間で24名で，受診者総数に対し

$0.04 \%$ ，年代では40代14名と最多であった。

(5)浸潤痢発見に関しては15名で，受診者総数に対し $0.02 \%, 60$ 代6名と 最多であった。

(6)老人保健法による娭診では，内診を施行することが望ましいとされて いるが，今回内診所見( 2 病院) も検討した。

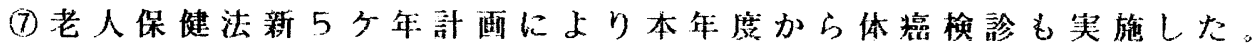




\section{乳腺疾患}

506

乳房自己検診の重要性について

一当院に括ける乳癌患者の背景因子の分析より一

\begin{tabular}{|c|c|c|c|c|c|c|}
\hline 前 & 真 & 澄 & 川 村 & 極 & 浜 & 砂 \\
\hline 野 & 幸 & 子 & 山 本 & 悟 & 樫 & 木 \\
\hline
\end{tabular}

岐阜岐北総合（病）

Iはじめ

生活椂式の洋風化に伴い、わが国における乳癌死亡数は年々堌加し、訂正 正罪患率によれば1993 年には女性では胃癌を抜を第一位になると予想され ている。当院でも乳腺外来受診者は増加の一途をたどつており、女性にとつ て乳癌は決して遠い存在でなくなつてをている。

一方、一般的飞子供のない婦人、授乳経験のない婦人に多いといわれており、

「私は乳癌にはならない」的な考方方をしている人す見受けられたため、当 院ではどのような状況であるのかを調べ、分析したのでここに報告する。

II 対象及び方法

昭和 $58 \sim 61$ 年までの乳癌患者のうち 100 名について、年令、発生部位、左 右差、授乳経験、出産児数、発見のきつかけ及び発見から受診までの期間に ついて調べた。

III 結 果及び考察

1) 年令分布

40 〜 4 歳が $32 \%$ と一番高く、50

代 30 代がそれに次いでいる。統計

と活活同率の結果であり、30〜

59 歳の中年発生率子統計の75.9\%

と近い7 7.4\%という結果となつ た。(図 1 )

2）乳癌発生部位及び左右差

多少の誤差はあるが、報告と同様、四分

円 C の部位に45\% と最子多く、

次いでAの $21 \%$ となり、乳房上

半分に好発していた。

左右差飞おいては、1 $10 ： 100$

で左にゃや多いといわれているが、

$61 ： 39$ と 1.5 倍龵ど多いという

私達の結果となつた。（表 1)

3) 出産児数及び授乳経験

（図1）年令分布

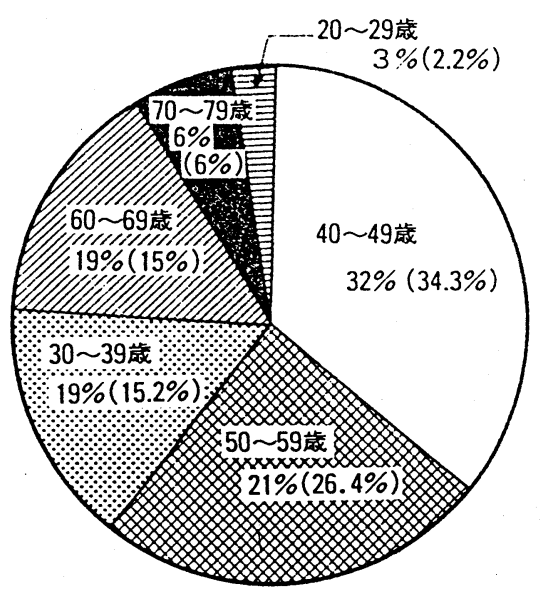

（）内は統計より

全体の $82 \%$ が授乳経験者で、未経験当ね18\%と少数であつた。

出産児数については、子供 2 〜 3 人人が乳癌患者の中では $71 \%$ と過 半数であつた。（表 2 )

4 ) 発見から受診までの期間と、乳癌の進行程度の関連

発見より比較的早期と思われる3ケ月以内の受診者飞は、早期の人が5 5 \%、stageII以上の進行癌の人は $45 \%$ であつた。

悩病期間の長いもの在ど進行癌が多いのではないかと思われたが、意外 にも昨日気づを来院の人にも進行癌がみられた。（図2） 
（表 1） 部位と左右差

\begin{tabular}{|c|c|c|c|}
\hline 部位 & 左 & 右 & 計 (続計より \\
\hline 四分丹 $A$ & 15 & 6 & $21(15 \%)$ \\
\hline B & 1 & 3 & $4(5 \%)$ \\
\hline C & 28 & 17 & $45(50 \%)$ \\
\hline D & 3 & 2 & $5(10 \%)$ \\
\hline$E$ & 3 & 3 & $6(20 \%)$ \\
\hline 光の他 & 11 & 8 & 19 \\
\hline 計\% & 61 & 39 & $100 \%$ \\
\hline
\end{tabular}

（表 $2 ）$ 出産览数及び

授乳経験の有無

\begin{tabular}{|c|c|c|c|}
\hline \multirow{2}{*}{ 出鷹况 } & \multirow{2}{*}{ 人数 } & \multicolumn{2}{|c|}{ 授 乳 } \\
\hline & & 有 & 無 \\
\hline-0 & 9 & & 9 \\
\hline 1 & 9 & 6 & 3 \\
\hline 2 & 46 & 43 & 3 \\
\hline 3 & 25 & 22 & 3 \\
\hline 4 & 8 & 8 & 0 \\
\hline 5 & 2 & 2 & 0 \\
\hline 6 & 1 & 1 & 0 \\
\hline 計 & 100 & 82 & 18 \\
\hline
\end{tabular}

（因2）発見から受診までの期間と乳癌の進行度

$$
\begin{array}{ll}
0=\text { stage I } & (n=39) \\
-=\text { stage II } & (n=19) \\
x=\text { stage III 以上 } & (n=12)
\end{array}
$$

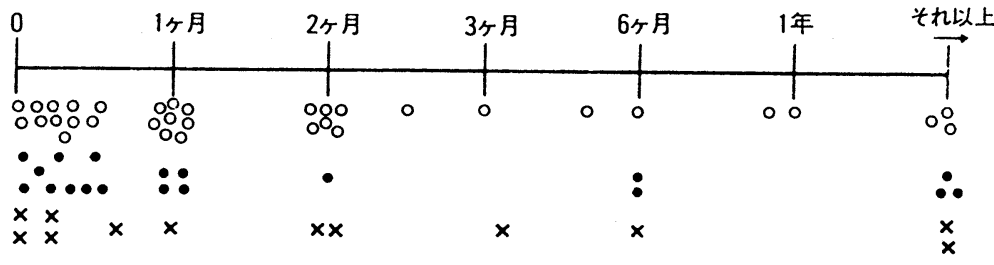

IV とめ

年令、部位、発見のをつかけ等に関しては、諸家の報告と在近近い結果であ つた。

出産、授乳経験については、対象が乳癌患者だけというとともあるが、授乳、 出産経験のある婦人に比較的多くみられ、「子供を生んだから私は大丈夫」 的な考えは、危険であると思われた。

悩病期間と進行程度の関係においては、75\%の人が腫瘤触知後了ケ月以内 に受診しているてとがわかつた。しかし、早期の受診でもstagell以上の進 行患者は、45\%すいた。とれは正確な自己検診法を知らずて腫瘤が大をく なりはじめて気づき、来院したるのと考えられた。また、乳癌と診断される のを恐れ、長期間受診をためらつたというケースる多くあり、一般人の癌に 対する恐怖心の強さを感じた。

\section{Vおわり}

今回の分析により、乳癌患者の90\%以上が自分で腫瘤を触れており、乳癌 発見には自己検診が大をな比重を占めているてとにより、乳癌て対する正確 な知識と正しい自己検診の啓蒙がますます必要であると考えられる。 
507 ゼロマンモグラフに扣ける乳腺間質型分類と疫学的関連性に関する検討（第一報）

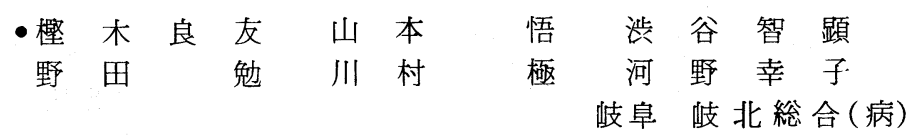

Iはじめに

岐阜市及び近郊農村婦人を対象に、ゼロマンモグラフに描出される乳腺間質像について間質 型分類を行ら、各分類型の出現頻度、年令階層別推移、ホルモン環境因子、臨床症状など、 乳癌との疫学的関連性を中心に検討した。

II 対象及び方法

対象：乳腺外来を受診した非乳癌症例、20才代 120 名、30才代388名、40才代337名、 50 才代 145 名、6 0 才以上 42 名、計1,032 名を対象とした。

方法：乳腺間質型分類は、ゼロマンモグラフの lateral view 用い、Wolfeの乳腺間質型分 類基準（表 1)飞従い、 $\mathrm{N}_{2} \cdot \mathrm{P}_{1} \cdot \mathrm{P}_{2} \cdot \mathrm{DY} \circlearrowleft 4$ 型に分類した。

III 結 果

1）各間質型の発現頻度

全例を通じ $\mathrm{N}_{1} 288$ 例 (28\%)、 $\mathrm{P}_{1} 288$ 例 (2 8\%)、 $\mathrm{P}_{2} 27$ 9例 (27\%)、DY 177 例 (17\%) と、乳腺間質増生度の低い $\mathrm{N}_{1} \cdot \mathrm{P}_{1}$

（表 1 ）

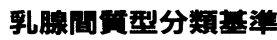

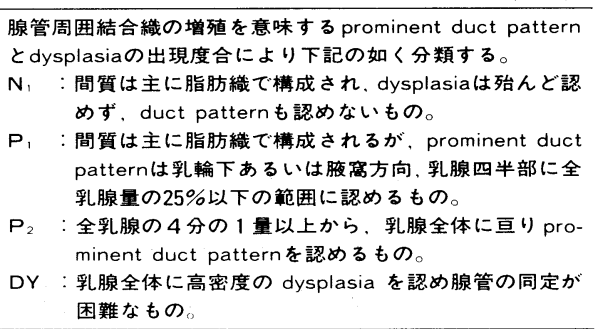
例のいわゆる「軟化乳腺」が症例の $56 \%$ を占めた。(図 1)

$2 ）$ 年令階層別各間質型発現頻度 年令別間質型発現順位は、2 0 才代で DY $\mathrm{N}_{1} \cdot \mathrm{P}_{2} \cdot \mathrm{P}_{1}$ と間質増生度の強いDY $\mathrm{P}_{2}$ 型のいわゆる「硬化乳腺」が症例の $66 \%$ を占めた。30才代では $\mathrm{N}_{1} \cdot \mathrm{P}_{2} \cdot \mathrm{P}_{1} \cdot \mathrm{D} \mathrm{Y}$ 、 40 才代では $\mathrm{P}_{2} \cdot \mathrm{N}_{1} \cdot \mathrm{P}_{1} \cdot \mathrm{DY}$ と $\mathrm{P}_{2}$ が最も高い出現率を示した。その後 50 才代では $\mathrm{P}_{1} \cdot \mathrm{P}_{2} \cdot \mathrm{N}_{1} \cdot \mathrm{DY}$ とな、6 0 才以上例では $\mathrm{P}_{1} \cdot \mathrm{N}_{1} \cdot \mathrm{P}_{2}$ とDYは1例もなく、 $\mathrm{P}_{2}$ の順位は後退し $N_{1} \cdot \mathrm{P}_{1}$ 型「軟化乳腺」が症例の79\%を占めるなど、各年代別几各間 質型の特徵的な推移変化を示した。(図 2)

( 図 1 )

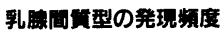

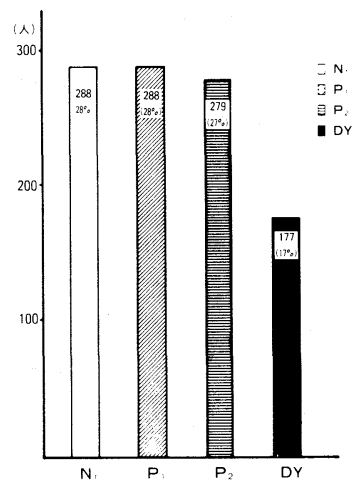

( 困 2 )

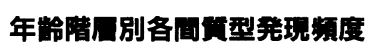

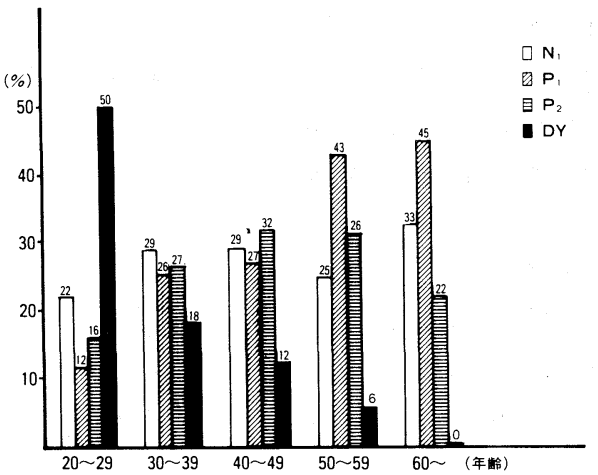


3) ホルモン環境と間質型

乳癌の高危険因子として、初潮年令・妊娠回数・初産年令・授乳などの関連性が挙げら れているが、今回の検討では、初潮年令 16 才以降例でD Y $5 \% 、 \mathrm{~N}_{1} 13 \cdot 3 \% 、 \mathrm{P}_{1} 17 \cdot 5$ $\% 、 \mathrm{P}_{2} 15 \cdot 4 \%$ と、D Yが他の型飞比べ若干初潮年令が低い傾向が認められた。（図 3 ） 出産回数では、3 回以上出産例飞 $\mathrm{N}_{1} \cdot \mathrm{P}_{1}$ 型の「軟化乳腺」が多い傾向が認められた。 (図 4)

しかし、初産年令・妊娠回数授乳等に関しては特に有意な関連性は認め岕かつた。

( 図 3 )

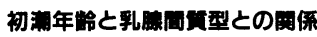

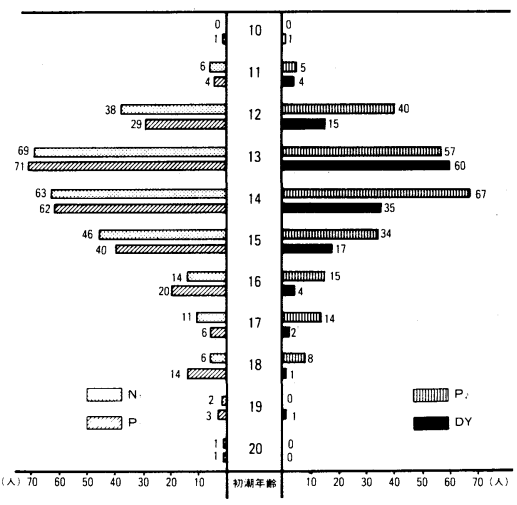

( 図 4 )

\section{出産回数と各間質型との関係}

$\begin{array}{llllllllll}10 & 20 & 30 & 40 & 50 & 60 & 70 & 80 & 90 & 100\end{array}$

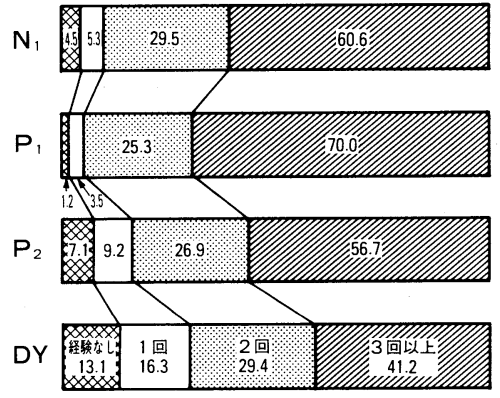

4 ）臨床症状と間質型

各間質型の受診理由「腫瘤触知」・「腫瘤触知及び疼痛」例は、 $\mathrm{N}_{1} 58 \cdot 9 \% 、 \mathrm{P}_{1} 54 \cdot 5 \%$ 、 $\mathrm{P}_{2} 59 \cdot 2 \% 、 \mathrm{DY} 73.5 \%$ 間質増生の強いDYにやや多い傾向を示したが、「腫瘤触知」 は各型に有意差は認めなかつた。（図 5 ）

5 ) 乳癌例の間質型

乳癌 51 例の間質型につ、て予備的検討を行つたところ、 $\mathrm{N}_{1}$ 型乳癌の $66.7 \% 、 \mathrm{P}_{1}$ 型 乳癌の $84 \cdot 6 \%$ が 50 才代以上の乳癌例であつた。

一方、 $\mathrm{P}_{2}$ 型乳癌の $55 \cdot 6 \%$ 、 DY 型乳癌の全例が 50 才未満の乳癌例で、 50 才未満乳癌 例の $88.5 \%$ は $\mathrm{P}_{2} \cdot \mathrm{DY}$ 型で占められ、極めて高い発生率を示した。（図 6)

(囝 5 )

\section{臨床症状と各間質型との関係}

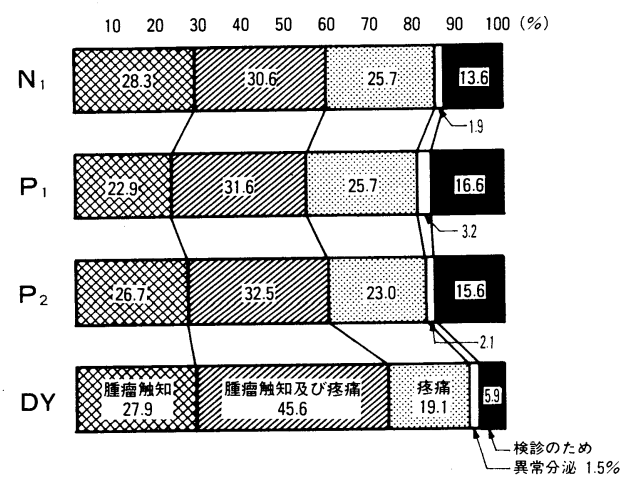

(図 6 )

\section{乳癌例における年齢別間質型分布}

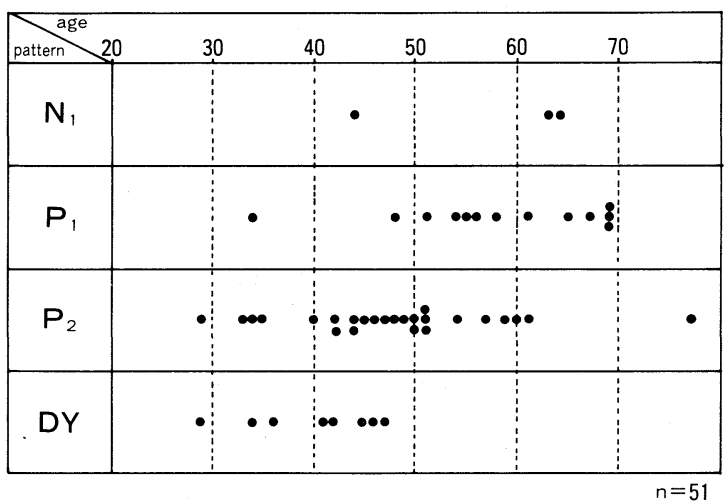

IV とめ

非乳癌 1,032 例の乳腺間質型につ、て疫学的関連性を中心に検討した。併せて乳癌例の間 質型について言及し、乳癌の高危険因子と間質型の関連性について報告した。 
$\bigcirc$ 山口直一, 根矢豊美, 大津仁蔵（茨厚連水戸協同病院 放射線科）海野倫明, 川口信哉, 前田正光, 新妻義

\section{1.はじめに}

文, 津久井一, 原田裕(同外科)

当院に於いては, 昭和 60 年 12 月より乳腺超音波検查としてメカニカルセク タースキャン方式の装置を使用し乳癌検診（出張集団検診も含む）に利用し ている。昭和 61 年 7 月より昭和 62 年 6 月までに当院にて超音波㭘查を施行し た症例は 1113 例, 病理組織診断を行い確定した症例は289例（25.9\%)で ある。乳癌を中心に触診で明らかな腫瘤として触知した 109 症例を対象にメ カニカル走查の成績を検討したので報告する。

\section{2. 対象および方法}

$\mathrm{T}$ a b 1 e 1 のでとく乳癌症例 32 例, 乳腺線維腺腫 33 例, 乳腺症 43 例（裹胞 9 例), 炎症 1 例である。使用機器はA 1 ok a S S 125 メカ二カルセクター 走查装置（ $7.5 \mathrm{MHz} ）$ を使用した。

\section{3. 成 績}

腫瘤の大きさ別内訳は $\mathrm{Tab} l \mathrm{e} 2$ 亿しめす。 $1 \mathrm{~cm}$ 以下（ 26 例），1〜2 cm ( 42 例 ) , $2 \sim 3 \mathrm{~cm}(27$ 例 ), $3 \mathrm{~cm}$ 以上 ( 14 例) である。乳癌症例について, 超音波所見では，確診例 27 例 $(84 \%)$, 疑診例 2 例 $(6 \%)$, 誤診例 1 例

( $3 \%)$, 描出不能例 2 例 $(6 \%)$ である。

病理組織診断で乳腺線維腺腫と確定された症例のうち超音波所見で確診で きないむのが13例にみられた。次ぎ，誤診例，鑑別困難例を示す。Fig 1 は辺縁比較的整, 内部エコ一一部みられるあ良性所見と思われたが, 組織診 断は悪性であった。Fig 2 は辺緣不整, 後壁一部脱落で悪性所見であるが組 織診断は良性である。Fig 3，Fig 4 は悪性を疑ったが組織診断ではそれぞ れ, 乳腺線維腺腫, 乳腺症であった。F i g 5 は同一乳癌症例のセクタ一走査 とコンパウンド走查の画像であり, F i g 6 は同一線維腺腫症例の両走査の画 像である。

Table 1

\begin{tabular}{|c|c|}
\hline 疾 患 名 & 症 例 数 \\
\hline 乳 & 32 例 \\
\hline 乳腺 線 維腺 腫 & 33 例 \\
\hline 乳腺症 (震胞) & $43(9)$ 例 \\
\hline 炎 & 1 例 \\
\hline 計 & 109 例 \\
\hline
\end{tabular}

Ta b 1 e 2

\begin{tabular}{|cccc|c|}
\hline \multicolumn{3}{|c|}{ 腫瘤の大きさ } & 症 例 数 \\
\hline 1 & $c m$ & 以 & 下 & $26(1)$ 例 \\
\hline 1 & $\sim$ & 2 & $c m$ & $42(11)$ 例 \\
\hline 2 & $\sim$ & 3 & $c m$ & $27(12)$ 例 \\
\hline 3 & $c m$ & 以 & 上 & $14(8)$ 例 \\
\hline 合 & \multicolumn{2}{|c|}{ 計 } & $109(32)$ 例 \\
\hline
\end{tabular}

（）内は乳癌症例 
F i g 1
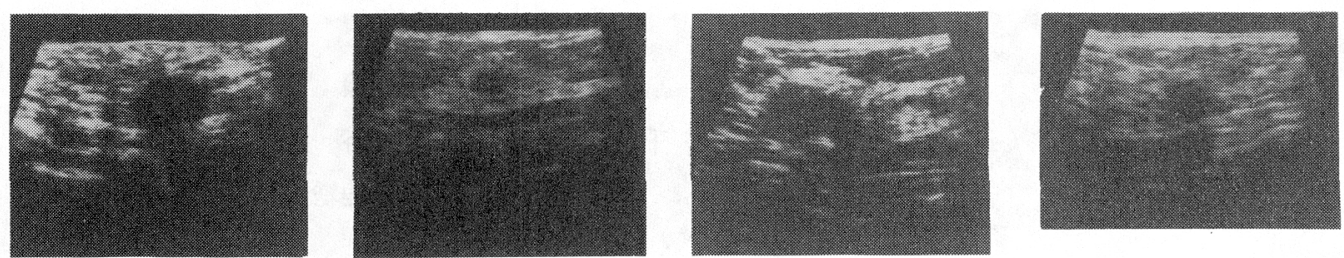

F i g 5
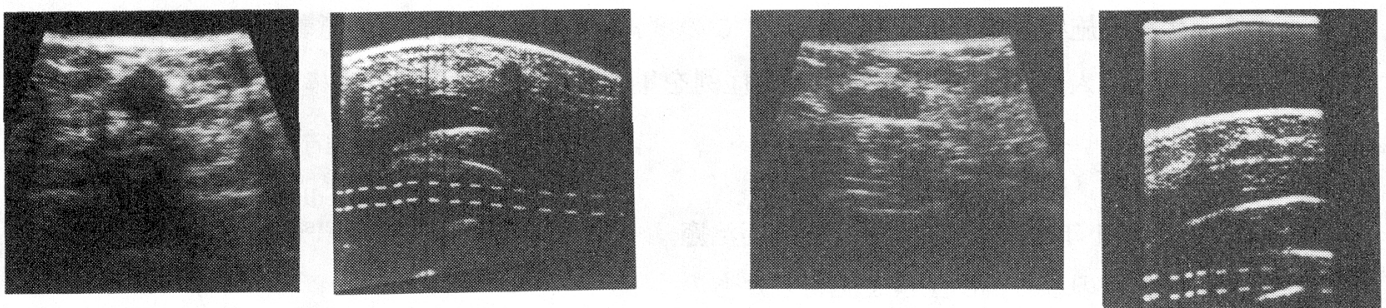

\section{4. 考 察}

乳腺腫瘤のうち, 今回は病理組織学的に診断の確定している症例で, 腫瘤 触知例( 癌, 線維腺腫, 乳腺症) 在検討した結果, 超音波検査(セクタ一走 査) の確診率は乳癌腫瘤では比較的高いが乳腺線維腺腫, 乳腺症腫瘤では鑑 別困難症例が比較的多かった。

又, セクタ一走査で乳癌を疑った症例に対してはコンパウンド走査を併用 して施行し, 診断率の向上をみた。

乳癌の描出不能例 2 例飞たいしては, いずれあ非常に小さい腫瘤であった。

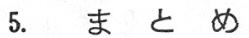

1. 超音波検査( セクタ一走查) は乳癌の診断には従来使用していた電子 スキャンタイプより有効な画像を得ることができた。

2. 出張乳癌検診に扣いてセクタースキャンは有効な検査法であり, 又診 断困難症例に対してコンパウンド走查を加え良好な結果をえた。 


\author{
○斉藤礼次郎, 松岡 富男, 赤石 隆, 遠藤 義洋 \\ 柴田隆, 浜田 千枝, 寺島 秀夫, 菅谷彪 \\ (秋田県厚生連平鹿総合病院外科)
}

〔はじめに〕

近年、マンモグラフィー、エコー等の補助診断法の進歩にともない、乳腺腫瘍の診断成績は著しく 向上した。特に穿刺吸引細胞診Needle aspiration biopsy 導入以後は、摘出生検Excisional biopsy を施行する症例は限定されてきている。当院では、触診所見より悪性を疑うあのの、マンモグラ フィーやエコー等の画像診断では良性悪性の確診がつかず、穿刺吸引細胞診であ陽性とでなかった症 例にのみ摘出生検を施行する方針としている。ての度、我々は、摘出生検の意義を再検討する目的で 穿刺吸引細胞診を導入した 1981 年以後の乳癌症例を集計、検討したのでててに報告する。

[摘出生検症例の検討]

1. 摘出生検施行率 (図 1 )

当院における 1981 年より 1986 年までの乳癌治癒 手術症例は94例、そのうち摘出生検を施行したもの は27例、生検率 $28.7 \%$ となっている。穿刺吸引細胞 診施行率は年々増加してきているのに対して、摘出 生検施行率は必ずしも低下して抢らず、穿刺吸引細 胞診が導入されてあ、確定診断のための摘生検の意 義は大きいと考えられる。

2. Stage, 腫瘍の大きさと摘出生検施行率 (表 1. 表 2)

Stage I では $60.1 \%$ 、腫瘍径が $10 \mathrm{~mm}$ 以下では 100 \%、11〜20mmでは $42.3 \%$ 之高率になっており、Stage (概治手術) の早い、小さな腫瘍では診断が難しく、摘出生検が行われ ることが多くなっている。

3. 摘出生検と術後再発、予後 (表 3 )

乳癌では後期再発が少なくないため、最近 6 年間の集計 では十分ではないが、摘出生検施行例の再発率は $11.1 \%$ 、 3 年生存率は $100 \%$ なの対して、非生検例では再発率 11 . $9 \% 、 3$ 年生存率 $92.9 \%$ 之生検例より不良な結果となって いる。非生検例にはStageの進んだ腫瘍径の大きい症例が 多く含まれているため、てのような結果になったと思われ る。

表 3. 摘出生検と術後再発、予後

\begin{tabular}{|c|c|c|}
\hline & 再発あり (\%) & 3 年生存 (\%) \\
\hline 生 検 例 & $3 / 27(11.1)$ & $15 / 15(100)$ \\
\hline 非生検例 & $8 / 67(7.9)$ & $26 / 28(92.9)$ \\
\hline 計 & $11 / 94(11.7)$ & $41 / 43(95.3)$ \\
\hline
\end{tabular}

図 1. 摘出生検施行率の年次推移

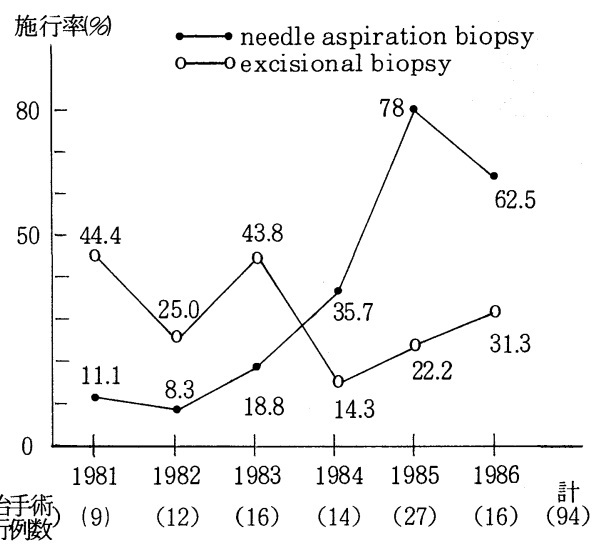

表 1. Stage と摘出生検施行率

\begin{tabular}{|c|c|c|c|}
\hline Stage & 症例 数 & 生 検 数 & 生検率 \\
\hline I & 23 & 14 & $60.1 \%$ \\
\hline II & 55 & 10 & $18.2 \%$ \\
\hline III a & 12 & 3 & $25.0 \%$ \\
\hline III b & 4 & 0 & $0 \%$ \\
\hline 計 & 94 & 27 & $28.7 \%$ \\
\hline
\end{tabular}

表 2. 腫瘍の大きさと摘出生検施行率

\begin{tabular}{|r|c|c|c|}
\hline 大きさ $m m$ & 症 例 数 & 生検 数 & 生検率 \\
\hline$\sim 10$ & 5 & 5 & $100 \%$ \\
\hline $11 \sim 20$ & 26 & 11 & $42.3 \%$ \\
\hline $21 \sim 50$ & 50 & 9 & $18.0 \%$ \\
\hline $51 \sim$ & 13 & 2 & $15.4 \%$ \\
\hline 計 & 94 & 27 & $28.7 \%$ \\
\hline
\end{tabular}


4. 生検部位の癌遺残亡術後再発（表 4)

摘出生検例27例中、乳腺の一部に癌の遺残を認めた、い わゆる「不完全摘出生検」例は 6 例であったが、根治術後 再発は 1 例むなかった。それに対して癌遺残を認めなかっ た完全生検21例のうち 3 例に術後再発を認めた。不完全摘 出による根治術後再発一の影響は認められなかった。

5. 摘出生検より根治手術までの日数と術後再発（表 5 ）

摘出生検より根治手術までの日数による術後再発率へ影 響は、我々の症例では明らかには認められなかった。

〔穿刺吸引細胞診の検討〕

1. 穿刺吸引細胞診の診断率 (表 6 )

当院における穿刺吸引細胞診全症例の正診率は $88.7 \%$ 、 class III を除いた正診率は 94.0 \% と良好な結果を得ている。 しかしながら、False negative 症例 (6.1\%)、False Positive 症例 2 例 $(5.7 \%$ ) が認められている。

2. False negative症例の検討（表 7 ）

臨床的に最も問題となるFalse negative 症例 5 例を検 討した。いずれあ穿刺吸引細胞診ではclass II であったが、 主に触診所見より悪性を疑われ、摘出生検を施行し、Carcinoma の診断を得た。

2 例は間質成分が多く陽性率が低いと言われているScirrhous $\mathrm{Ca}$ 。であった。また 1 例はCyst を形成したMucinous $\mathrm{Ca}$. であり、内容液のみを吸引したあのと思われた。 Solid tubular Ca.の 2 例は採取された細抱数が少く、適 確な穿刺がなされなかったものと思われた。
表 4. 摘出生検部位の癌遺残亡再発

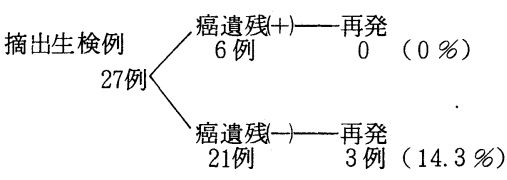

表 5. 摘出生検より根治手術までの日数と再発

\begin{tabular}{|c|c|c|c|}
\hline 日 数 & 生検例 & 再発例 & 再発率 \\
\hline$\sim 7$ 日 & 5 & 1 & $20.0 \%$ \\
\hline 8日～14日 & 10 & 1 & $10.0 \%$ \\
\hline 15日～28日 & 7 & 0 & $0 \%$ \\
\hline 29日〜 & 5 & 1 & $20.0 \%$ \\
\hline 計 & 27 & 3 & $11.1 \%$ \\
\hline
\end{tabular}

※平均日数 15.9 日（6日～ 36 日）

表 6. 穿刺吸引細胞診の診断率 ( 1981 年 1986 年)

\begin{tabular}{|c|c|c|c|}
\hline Class & 例 & malignant & benign \\
\hline I & $11 \mathrm{~T}_{8}$ & $0-$ & 11777 \\
\hline II & $71\rfloor^{82}$ & $5]^{5}$ & $66-{ }^{71}$ \\
\hline III & $(5.8 \%)$ & 3 & 4 \\
\hline $\mathrm{N}$ & $17_{35}(28,2 \%$ & 1732 & $07 ?$ \\
\hline $\mathrm{V}$ & $34-^{35(28.2}$ & $31-$ & $2-^{2}$ \\
\hline 計 & $(100 \%)$ & & \\
\hline
\end{tabular}
A) Diagnostic accuracy class I, II, II, I, V 110./ $124(88.7 \%)$ class I, II, N, V 110/117 (94.0\%)

B) $\frac{\text { False negative }}{\text { class I , II }}$ False Positive class $\mathrm{N}, \mathrm{V}$ $5 / 82 \quad(6.1 \%)$ $2 / 35 \quad(5.7 \%)$

表 7. False negative 症例の検討

\begin{tabular}{|c|c|c|c|c|c|c|c|c|c|c|}
\hline \multirow[b]{2}{*}{ 症 例 } & \multirow[b]{2}{*}{ 年令 } & \multirow{2}{*}{ 局，在 } & \multirow{2}{*}{\multicolumn{2}{|c|}{$\mathrm{T} \quad(\mathrm{cm})$}} & \multirow{2}{*}{$\mathrm{N}$} & \multirow[b]{2}{*}{ stage } & \multicolumn{3}{|c|}{ 触 } & \multirow[b]{2}{*}{ Histology } \\
\hline & & & & & & & shape & Consistency & dimpling & \\
\hline A, M & 33 & (右) DC & $\mathrm{T} 1$ & $1.5 \times 1.5$ & $\mathrm{~N} 1 \mathrm{~b}$ & II & irregular & elastic firm & $(+)$ & Solid-tubular $\mathrm{Ca}$ \\
\hline $\mathrm{K}, \mathrm{T}$ & 62 & (左) CA & $\mathrm{T} 1$ & $1.3 \times 0.8$ & $\mathrm{~N} 0$ & $\mathrm{I}$ & irregular & elastic firm & $(+)$ & Scirrhous $\mathrm{Ca}$. \\
\hline K, M & 63 & (左) CA & T2a & $3.0 \times 3.0$ & $\mathrm{No}$ & II & irregular & elastic firm & $( \pm)$ & Scirrhous Ca, \\
\hline$T, S$ & 71 & (右) A & T2 a & $2.7 \times 2.5$ & $\mathrm{No}$ & II & round & elastic soft & $(-)$ & Mucinous $\mathrm{Ca}$, \\
\hline $\mathrm{H}, \mathrm{K}$ & 51 & (左) A & $\mathrm{T} 2 \mathrm{a}$ & $2.4 \times 2.0$ & $\mathrm{~N} 0$ & II & irregular & elastic firm & $(-)$ & Solid-tubular $\mathrm{Ca}_{0}$ \\
\hline
\end{tabular}

\section{〔まとめ)}

乳癌、殊に早期乳癌の増加が予想される現在、画像診断と共に、穿刺吸引細胞診の価値は高い。 しかし、微少乳癌や T 0 症例、Scirrhous Ca. ではその精度が落ちざるをえず、その意味で摘出生 検の価値には大きなあのがあり、今後とあ乳癌の診断において大きな位置を占めるあのと思われる。 
510 佐久総合病院における乳癌とホルモン受容体につんて

柳沢昭吾, 池田昌伸。船崎善三郎

(長野県・佐久総合病院)

(はじめに) 新しい抗ホルモン郕の登場により、乳癌の内分泌療法が再認識さ れているが、一体乳癌のホルモン依存性はどの程度のるのなのか当院の実状をし らべてみた。

（対象と方法）昭和56年10月より昭和 62 年1月までに臨床診断による根治手術 の際、或いは生検の際に腫瘍組織の一部を冷凍保存して病理組織学的診断決定と 共にエストロゲンレセブター（ $\mathrm{ER} ＼textrm{R})$ とブロゲステロンレセブター（P R ）とを測定した 94 例を対象とした。この間に於ける全手術例は154 例であるからレセブター測定例 は全体の61\%である。Radio-Receptor-assdy（DC C 法）による。

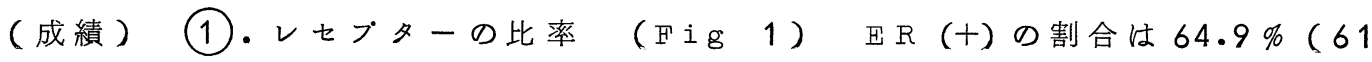
例）、 $\mathrm{ER}(-)$ は33\%（31例）で、その内訳は $\mathrm{ER}(+) \mathrm{PR}(+)$ が全体の $37.2 \%$ （35例）、 $\mathrm{ER}(+) \mathrm{PR}(-)$ は $27.7 \%$ (26例)、ER (-) PR (+) $4.3 \%$ (4 例)、 $\mathrm{ER}$ (一) PR（一) $30.9 \%$ ( 29 例) であった。

(2). 年代別（Fig 2) 全症例を年代別飞分けると、50才代をピークに29例 $(31.2 \%)$ 、以下 40 才代 24 例（25.8\%)、60才代 $18(19.3 \%) 、 70$ 才代11(11.8 $\%) 、 30$ 才代 $9(9.0 \%) 、 80$ 才代 $2(2.1 \%)$ ありり、各レセブター率もこれに略準 じている。(3). 病理組織別（Fig 3) 充実腺管癌( SOLID TUB.) 38 例 $(40.9 \%)$ 、乳頭腺管癌 ( PAPILLO TUB.) 24 例 ( $25.8 \%$ )、硬癌 (S CIRRHOUS) 16 例 (17.2\%)、その他（OTHERS）７例（7.5\%）で各レセブタ一率もこれに準じ ている。(4). 腫瘍の大をさ別（Fig 4) $\mathrm{T}_{2}$ が一番多く51例( $86 \%$ )、以下
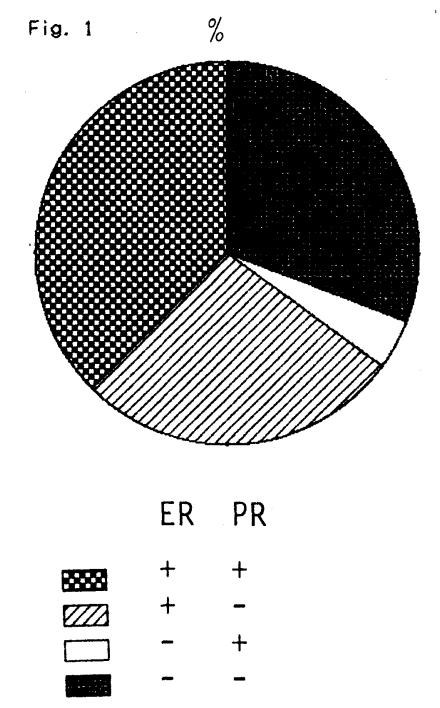

EXAMPLE $>$ $\mathrm{T}_{1} 20$ 例 (23.2\%)、 $\mathrm{T}_{3} 9$ 例 $(10.5 \%) 、 \mathrm{~T}_{4} 6$ 例 (7\%)で レセブター率す同様である。症例の少ら $\mathrm{ER}(-)$ $\mathrm{P} R(+)$ を除く。

(5).リンバ節転移別（（Fig 5 ） N 50 例 (61\%) $\mathrm{N}_{1} 20(24.4 \%) 、 \mathrm{~N}_{2} 9(11 \%) 、 \mathrm{~N}_{3}(3.7 \%) 、$ でセブ

Fig. 2

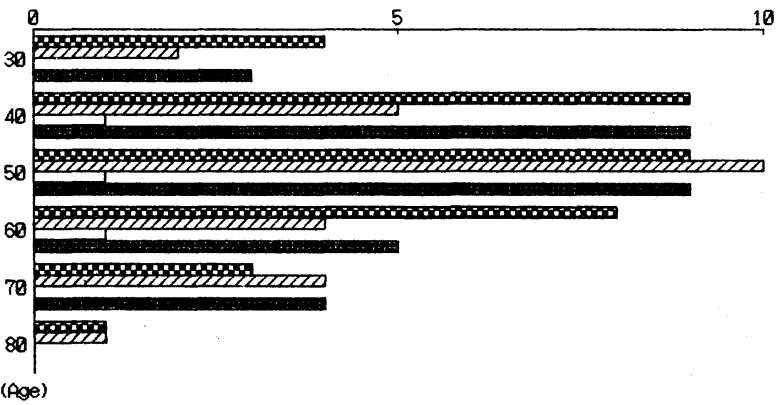


ター率は ER (一) P R (十)を除いて同様である。

(考案) 日本人乳癌のER(十)の割合は一般に58〜60\%と言われているが、我々 の成績は64.9\% と若干高率で欧米人(米国人乳癌71\%)飞近い。従って $\mathrm{ER}($ ） は

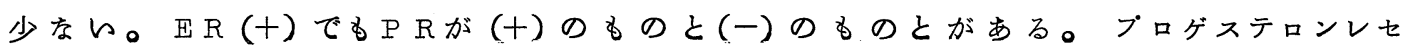
ブター（PR) は女性ホルモンの作用の結果生合成される蛋白であるから $\mathrm{P} R(-$ は ERがあってすエストロゲン非依存性と言うことになるが、61例中 26 例 $42.6 \%$ 存在 しており、これは諸家の成績 $49 \%$ ら若干低かった。僅かの差であるがホルモン療 法有効率に影響があると思われる。閉経前後でのレセブター率をみると、（Fig 2 参照) 55 才で区切って $\mathrm{ER}(+)$ の場合閉経前 45例 (70.2\%)、後 16例 (53.3\%)、E R (一)では前 19 例 $(29.7 \%)$ 、後 14 例 $(46.7 \%)$ と明らかに閉経後は $\mathrm{E} R(-)$ 例が増し ている。これは日本人乳癌の特徵といわれており、欧米乳癌では閉経後のE $\mathrm{R}(+)$ の割合は高いという。一般にER(十)の乳癌はER (一) 乳癌よりる臨床的に悪性度

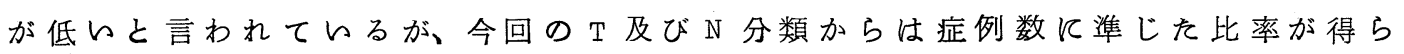
れただけであった。又、病理組織学的分類からす予測は得られなかった。

(結語)

佐久総合病院に於ける乳癌の ホルモン受容体を調查した結果 (1). $\mathrm{ER}(+)$ の乳癌は全体の $64.9 \%$ を占め、日本人平均上 り若干高かった。

(2). $\mathrm{ER}(+)$ 中ですエストロ ゲン非依存性のP R (一) 乳癌 は、 $42.6 \%$ と諸家の成績より 低加灰。

(3). 組織学的, 大ささリンハ 節転移分類では差異はみられ なかった。

(4). 閉経前後のレセブター率で は、閉経後のER (一) 率が高 かった。
Fig. 3

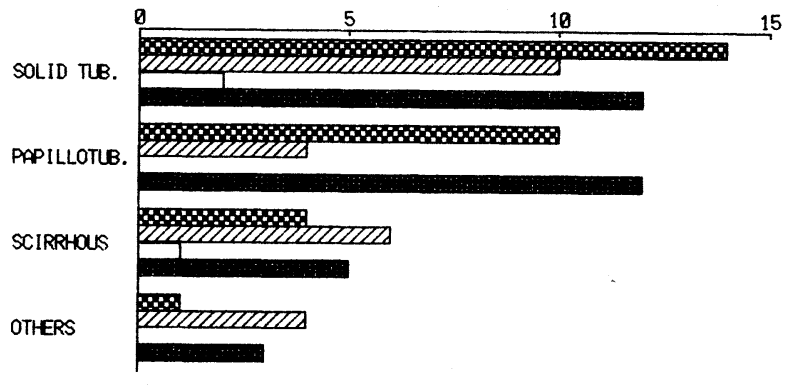

Fig. 4

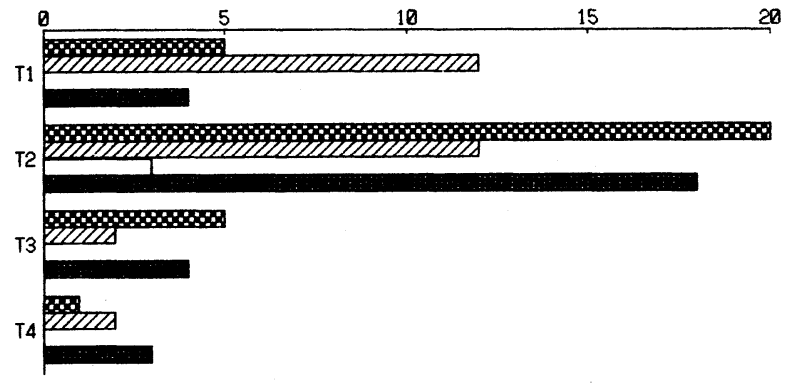

Fig. 5

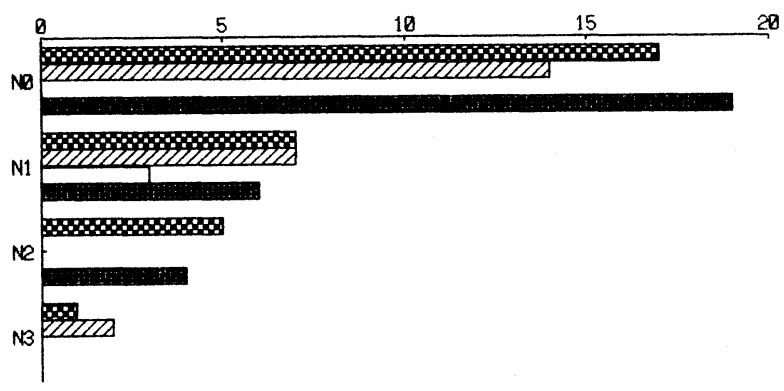


島田美由紀, 石簿由美子, 美留町 上山里美子, 市村しづ子, 萩原京子

(土浦協同病院呼吸器科)

\section{くはじめに>}

慢性呼吸不全患者の増加とともに，人工呼吸器を長期に装着する例が増 えている今日, 増悪因子，離脱を妨げる因子として感染が大きな問題とな っている。長期人工呼吸器装着患者に対し, 経時的に回路内の細菌培養検 查を施行した結果, 従来の報告と同様緑膿菌（以下Psと略す）が，高率に 検出された。そこで, Ps感染の対策として, 消毒法, 回路, その他の付属 器交換間隔等について検討したので報告する。

\section{$<$ 対象及び方法>}

対象は72才の男性とした。陳旧性肺結核により慢性呼吸不全に至り，昭 和 55 年入院。急性増覀時のみ人工呼吸器を装着し, 入退院をくり返してい たが, 昭和 60 年より現在に至るまで継続して人工呼吸器を装着している。

方法として, 図 1 に示した通り採取部位を決めた。(1)の痰は, 吸引検体 採取容器, (2) (6) (2) (3) は, 咽頭培養容器を使用し, 1 日 1 回採取。(12) (9) (11) は, 滅菌スピッッを使用し，1 日 4 回，6 時間毎に採取。各々，3 日毎 2 週間を 1 クールとして採取した。培養方法は， B T B ，血液，チョコ寒 天培地飞よる簡易定量法にて, 数コ, 少数, $(+),(+\#),($ H) と基準を定めた。 そして, 従来の消毒法 $0.1 \%$ ビテンによる 1 日 1 回の気切部包交を, (a) ソジン, (b) $0.5 \%$ ヒビテンアルコール, (C) ゲンタマイシン軟膏塗布し, 1 日 2 回包交。さらに, 吸引用 $0.125 \mathrm{ppM} \mathrm{AgHCO}_{2}$ 精製水を滅菌精製水に, 0.1 ヒビテ ンを $0.5 \%$ ヒビテンアルコールに変更し, 比較実験した。

\section{<結果及び考察 >}

表 1,2 参照

以上の結果により, ジャバラ, カニューレの交換前に拈いても, Ps が検 出されたのが (1) ( 3)のみであったてとから, それ程頻回な交換は必要ない と思われる。そこで焦点を(1)〜 (3) 絞り実験した。すでにPsに感染してい る症例であるので, 喀㷋及び気切部よりのPsの検出は予想通りであるが, てれをいかにして少なくするかを今回の目的とした。まず消毒の強化とし て。従来 $0.1 \%$ ヒビテンのみで消毒していた気切部を, イソジン, $0.5 \%$ ヒビ テンアルコール, ゲンタマイシン軟亳塗布に変え 1 日 2 回とし, Psを減少 させることができた。次に, 吸引用精製水と0.1\%七ビテン中にPsは検出さ れていなかったが, Ps以外の NFB (ブドウ糖否発䤉グラム陰性桿菌) が 数コ〜(十)認められた。乙れを $0.5 \%$ ヒビテンアルコール, 滅菌精製水に変え ることにより(-)となった。しかし, (1)〜 (3) のPs は数〜 (十)検出されているた 


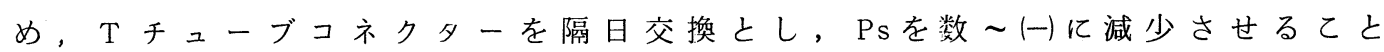
ができた。

気切口は, 直接患者の体内に通じる部分であり, 感染経路になり易い。 そこで, 気切ロに通じる付属部品, 又直接気切ロに入るカテーテル等を, より無菌に近い状態に保つため, 消毒の徹底, 頻回な付属部品の交換を行 いPs の検出率を減少させるととが出来たという事は, 今回の大きな成果で ある。

\section{$<お わ り に>$}

長期人工呼吸器装着患者のPs感染予防体策として, 従来当病棟で行われ ていた消毒法を再検討し, 改善するてとによって, Ps 検出率を低下させる 事が出来た。今後む今回の研究で得た成果をあとに, 更によい方向へと研 究しっづけたいと思う。

図 1 検体採取部位と名称

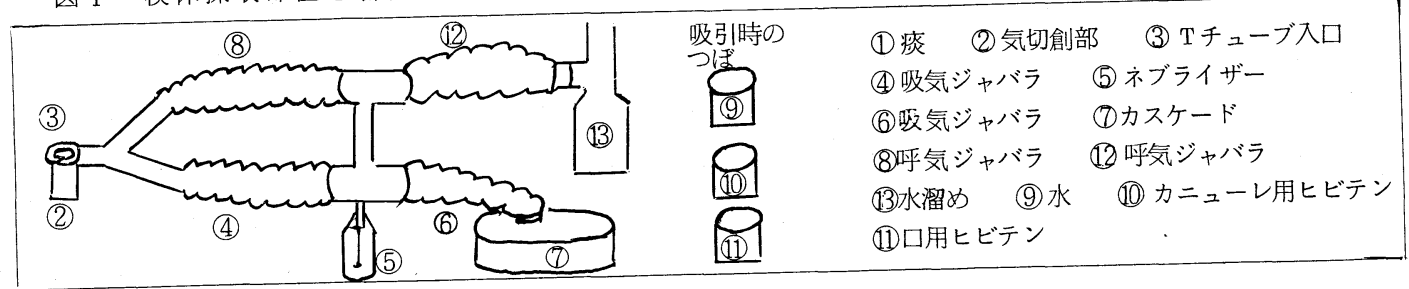

表 1 回路内細菌培養の経時的比較

\begin{tabular}{|c|c|c|c|c|c|c|c|c|c|c|c|c|c|}
\hline & ジャバラ & & & & & (ソジン & b) $0.5 \%$ t & (C) & GM塗布 & T千斗 & -ブ隔日 & 文換 & \\
\hline & 交換前 & 交換 3日目 & 6日目 & 9 日目 & 12 日目 & 3自自 & 百自 & 9日筧 & 12日目 & 3日目 & 6日目 & 9日目 & 12日目 \\
\hline & $\operatorname{PS}(H)$ & $\operatorname{PS}(\#)$ & PS数 & $\mathrm{PS}(+)$ & $\mathrm{PS}(+)$ & $\mathrm{PS}(+)$ & PS少 & PS 数 & PS 数 & $\mathrm{PS}(+)$ & PS 少 & S 少 & PS 数 \\
\hline (1) & $\mathrm{NFB}(t)$ & $\mathrm{NFB}(+)$ & & $\operatorname{NFB}(+)$ & & & & & & & & & \\
\hline (2) & $\begin{array}{l}\mathrm{PS}(\mathbb{H}) \\
\mathrm{NFB}(\mathbb{H})\end{array}$ & $\operatorname{PS}(t)$ & PS(t) & $\operatorname{PS}(+)$ & PS (H) & PS $(+)$ & $\operatorname{PS}(t)$ & PS (t) & $(-)$ & $\operatorname{PS}(+)$ & PS $(+)$ & PS 数 & $\operatorname{PS}(+)$ \\
\hline (3) & PS (+) & PS以外の & $\mathrm{PS}(+)$ & $\begin{array}{l}\text { PS以外の } \\
\text { NFB数 }\end{array}$ & $\mathrm{NFB}(+)$ & $(-)$ & $(-)$ & $(+)$ & $\operatorname{PS}(+)$ & $(-)$ & $(-)$ & $(-)$ & PS少 \\
\hline (4) & $\left|\begin{array}{c}\text { NFB (A) } \\
(-)\end{array}\right|$ & $\begin{array}{c}\text { NFB 数 } \\
(-)\end{array}$ & $(-1)$ & $(-1)$ & $(-)$ & $(-)$ & $(-)$ & $(-1)$ & $(-)$ & & & & \\
\hline (5) & $(-)$ & $(-)$ & $(-)$ & $(-)$ & $(-)$ & $(-1)$ & $(-)$ & $(-)$ & $(-)$ & & & & \\
\hline (6) & $(-)$ & $(-)$ & $(-)$ & $(-)$ & $(-1)$ & $(-)$ & $(-1)$ & $(-)$ & $(-)$ & & & & $1-1$ \\
\hline (8) & $(-)$ & $(-)$ & $(-)$ & $(-)$ & $(-)$ & $(-)$ & $(-)$ & $(-1)$ & $(-)$ & $(-1)$ & $(-1)$ & $(-1$ & $(-1)$ \\
\hline (12) & $(-)$ & $(-)$ & $(-)$ & $(-)$ & $(-)$ & $(-1)$ & $(-)$ & $(-)$ & $(-)$ & $(-)$ & $(-1)$ & $(-)$ & $(-1)$ \\
\hline (13) & $(-)$ & $(-)$ & $(-)$ & $(-1)$ & $(-1)$ & $(-)$ & $(-)$ & $(-)$ & $(-1$ & $(-)$ & $(-)$ & $(-)$ & $(-)$ \\
\hline
\end{tabular}

表 2 消毒液内細菌培養の比較

\begin{tabular}{|c|c|c|}
\hline & $\mathrm{Ag} \mathrm{HCO}_{3}$ 精製水 $0.1 \%$ ヒビテン & 滅菌精製水 $0.5 \%$ ヒビアル \\
\hline (7) $\begin{array}{ll}8^{\circ} & \text { (使用前) } \\
0^{\circ}\end{array}$ & $\begin{array}{c}\text { NFB（数） } \\
\prime \prime\end{array}$ & $\begin{array}{c}\text { NFB }(-) \\
\text { " }\end{array}$ \\
\hline (9) $\begin{array}{l}8^{\circ} \\
0^{\circ}\end{array} \quad$ (使用前) & $\begin{array}{c}\text { NF B (数) } \\
\prime \prime\end{array}$ & $\begin{array}{c}\text { NFB } \\
\prime \prime \\
\end{array}$ \\
\hline (10) $\begin{array}{ll}8^{\circ} & \text { (使用前) } \\
0^{\circ}\end{array}$ & $\begin{array}{c}\text { NF B (数) } \\
\text { " }\end{array}$ & $\begin{array}{c}\text { NFB }(-) \\
\prime \prime\end{array}$ \\
\hline (11) $\begin{array}{ll}8^{\circ} & \text { (使用前) } \\
0^{\circ}\end{array}$ & $\begin{array}{l}\mathrm{NFB} \text { (数) } \\
\prime \prime\end{array}$ & $\begin{array}{c}\text { NF B }(-) \\
\prime \prime\end{array}$ \\
\hline
\end{tabular}




\section{2 当院における緑膿菌について}

$\bigcirc$ 本多照夫, 杉田晴美, 中川晋

( 総合病院水戸協同病院中央検查科)

目的：従来, 緑膿菌は創傷に二次的感染症を起乙し難治性の化膿性疾患として, 外科 領域では重要視されてきた。近年, 広域抗生剤の使用や抵抗力の減弱主 (compromised host)の増加に伴って, 緑膿菌の増加傾向が見られる。平素無害菌 (opportunistic pathogen) 又は弱毒菌（プロテァーゼ, エラスターゼが最も重要視されている）とさ れ宿主因子要素により大きく左右されるopportunistic infection の起因菌として 注目されている。今回, 私達は当院の分離状況や血清群別, 薬剂感受性について調べた ので報告する。

方法：1984年 2 月から 1987 年 1 月までの 3 年間に当院各種臨床材料より分離されたも のを,オキシファームチューブII（ロシュ）で同定した 351 株を用いた。

尚, 集計にあたって同一患者, 同一材料由来株は 1 株と集計した。薬剤感受性試験は感 受性ディスク用培地 $N$ (日水) を用い, 昭和一濃度ガラス玉法を使用し, 判定はH〜H を感性, 十〜一を耐性とした。使用薬剤は抗緑膿菌剤とされる G M, S B P C, C B P C, $\mathrm{C} L, \mathrm{KM}, \mathrm{DKB}, \mathrm{TOB}, \mathrm{MINO}, \mathrm{AmK}$, と第三世代セフェム系の L M OX, C P $Z, C T X, C Z X$, の 4 剤を加えた 13 薬剤を使用した。又, 疫学的に把握する為に血 清群別を市販の緑膿菌診断用免疫血清を用いて調べた。

成績：本菌の材料別分離頻度上位 5 の内訳は表 1 の如く尿由来 108 株 (30.8\%), 膿, 分泌物 89 株 (25.4\%), 喀痰 71 株 (20.2\%), 胆汁, 便各々 (10.2\%)の順に多く検出された。 血清群別上位 5 の内訳は表 1 の如く $\mathrm{G}$ 群 90 株 (25.6\%) が最も多く, 次にH群 70 株 (19.9\%)。 A 群 44 株 (12.5\%), I 群, 型別不能各々 30 株 (8.5\%)の順に多く, 少数ながら J 群, K 群, $\mathrm{L}$ 群も各々 1 株検出された。薬剤感受性は表 2 の如く C L が $(94.9 \%)$ と最も高い有効性 を示した。アミノグリコシド系では G M (82.9\%)， T O B (82.9\%)，D K B (82.6\%), A $\mathrm{m} \mathrm{K}(82.3 \%)$ と高い感性率を示している反面, K M は $(3.7 \%)$ の感性率であった。ぺ二 シリン系ではS B P C (60.4\%)，ＣＢＰＣ（35.6\%)，テトラサイクリン系Ｍ I N O (20.8\%) であった。セフェム系 4 剤では C P Z (78.1\%), L MOX (63.5\%), C TX (63.0\%), C $Z X(41.0 \%)$ の順であった。 3 年間を年度別表で見ると表 3 , 表 4 , 表 5 の如く年を追 うごとに全般に耐性株の増加が見られた。特に C B P C ( 61.5\%, 19.4\%, 16.2\%) の感 性率，MINO（44.8\%，13.6\%，1.9\%）と耐性株の急増が見られた。

考察: 材料別では病棟優位を示し, 尿由来之濃, 分泌物で半数以上を占めた。血清群 別では各種材料別から $\mathrm{G}$ 群が多く検出されたが胆汁のみが 36 株中 31 株が $\mathrm{H}$ 群で $\mathrm{G}$ 群は 1 株であり, 病院内の流行菌株を示す結果となった。薬剂感受性試験は C L ( $5.1 \%)$ の耐 性株があったものの今回の13薬剤中では最む高い有効性を示し, アミノグリコシド系の $\mathrm{KM}$ を除く G M, D K B, T O B , A m K が安定した有効性を示した。又, 予想以上に C B P C, M I N O を筆頭に薬剂全般飞耐性株の増加傾向が見られ, 今後もこの様な傾向 が益々増大して行くものと思われる。 


\section{表 1 材料別の血清群別数}

（1984年 2 月～ 1987 年 1 月,総検体数 351 株)

\begin{tabular}{|c|c|c|c|c|c|c|c|c|c|c|c|c|c|c|c|c|}
\hline $\begin{array}{l}\text { 血清群別 } \\
\text { 材 料 }\end{array}$ & A & B & C L $\mathrm{L}$ & D 1 & & $F \quad C$ & I & 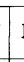 & $J$ & $\mathrm{~K}$ & I & & 1 㔈 & & 計 & 96 \\
\hline 尿 由 来 & 6 & 3 & 3 & 6 & & 93 & & & & & & & & 8 & 108 & 30.8 \\
\hline 朖 分泌物 & 14 & 11 & 1 & 3 & & 62 & & & & & & & & 4 & 89 & 25. \\
\hline 痰 & 13 & 2 & 1 & 4 & & 21 & & 1 & & & & & & 11 & 71 & 20.2 \\
\hline i十 & 2 & & 1 & & & 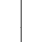 & 3 & & & & & & & & 36 & 10. \\
\hline 便 & 6 & 3 & 2 & 3 & & 2 & & & & & & & & 6 & 36 & 10.2 \\
\hline 柲嘈㽬粘液 & 2 & & & 2 & & & & & & & & & & 1 & 6 & \\
\hline 刺 液 & & & 1 & & & & & & & & & & & & 3 & \\
\hline 静 先 端 & 1 & & & & & & & & & & & & & & 2 & \\
\hline 計 & 44 & 19 & 91 & 181 & & 199 & & & & & & & & 30 & 351 & $100 \%$ \\
\hline
\end{tabular}

表 3 薬剤に対する耐性数

( 1984 年 2 月 1985 年 1 月, 検体数 143 株)

\begin{tabular}{|c|c|c|c|c|c|c|c|c|c|c|c|c|c|c|c|c|}
\hline 血清群別 & A & B & C & $\mathrm{D}$ & $\mathrm{E}$ & F $\mathrm{G}$ & $\begin{array}{lll}\mathrm{G} & \mathrm{H}\end{array}$ & H I & I & $\mathrm{K}$ & & & 裂㶪能 & 計 & 䙵％ & 䌠 96 \\
\hline \multicolumn{17}{|l|}{$\begin{array}{l}\text { 通性数 } \\
\text { 䔮剂各 }\end{array}$} \\
\hline G M & & & & 3 & & & & 12 & 2 & & & & 1 & 7 & 4.9 & 95.1 \\
\hline SBPC & 4 & 2 & 1 & 6 & 1 & \begin{tabular}{l|l}
4 & 1
\end{tabular} & \begin{tabular}{l|l}
10 & 7
\end{tabular} & \begin{tabular}{l|l}
7 & 1
\end{tabular} & 1 & & 1 & & 1 & 38 & 26.6 & 73.4 \\
\hline CBPC & 6 & 3 & 2 & 5 & 4 & \begin{tabular}{l|l}
6 & 1
\end{tabular} & \begin{tabular}{l|l}
15 & 10 \\
\end{tabular} & 10 & 1 & & 1 & & 2 & 55 & 38.5 & 61.5 \\
\hline C L & & & & & 1 & & 1 & 1 & & & & & & 3 & 2.1 & 97.9 \\
\hline K $\quad M$ & 16 & 8 & 4 & .9 & 8 & \begin{tabular}{l|l}
5 & 4
\end{tabular} & \begin{tabular}{l|l}
43 & 28
\end{tabular} & 2213 & & 1 & & 1 & 6 & 136 & 95.1 & 4.9 \\
\hline D K B & & & & 3 & & & & 23 & 2 & & & & 1 & 8 & 5.6 & 94.4 \\
\hline T O B & & 1 & & 3 & & & 1 & 11 & 1 & & & & 1 & 8 & 5.6 & 94.4 \\
\hline MINO & 9 & 3 & 3 & 5 & 7 & \begin{tabular}{l|l}
6 & 2
\end{tabular} & \begin{tabular}{l|l}
29 & 13
\end{tabular} & 13 & 4 & & & & & 79 & 55.2 & 44.8 \\
\hline $\mathrm{A} \mathrm{m} \mathrm{K}$ & & & & 2 & & & 1 & 2 & & & & & 1 & 6 & 4.2 & 95.8 \\
\hline LMOX & 5 & 2 & 2 & 2 & 1 & \begin{tabular}{l|l}
2 & 1
\end{tabular} & 10 & \begin{tabular}{l|l}
7 & 1
\end{tabular} & 1 & & 1 & & 3 & 36 & 25.2 & 74.8 \\
\hline C P Z & 1 & 1 & 1 & 1 & 1 & 1 & 6 & 5 & & & & & 1 & 18 & 12.6 & 87.4 \\
\hline $\mathrm{CTX}$ & 6 & 3 & 1 & 5 & 2 & & 12 & 6 & 1 & & & & 2 & 41 & 28.7 & 71.3 \\
\hline C $2 x$ & 10 & 5 & 3 & 6 & 4 & \begin{tabular}{l|l}
5 & 1 \\
\end{tabular} & 18 & 9 & 2 & & & & 4. & 66 & 46.2 & 53.8 \\
\hline
\end{tabular}

表 5 薬剤に対する耐性数

（1986 年 2 月～ 1987 年 1 月，検体数 105 株 )

\begin{tabular}{|c|c|c|c|c|c|c|c|c|c|c|c|c|c|c|c|c|c|}
\hline 血清群別 & A & B & C & D & E & $\mathrm{F}$ & G & $\mathrm{H}$ & I & J & $\mathrm{K}$ & L & $\mathrm{M}$ & 型䂰能 & 計 & 㖇 96 & 感\% \\
\hline \multicolumn{18}{|l|}{$\begin{array}{l}\text { 面惺数 } \\
\text { 薬剂各 }\end{array}$} \\
\hline $\mathrm{G} \quad \mathrm{M}$ & 4 & & & & 2 & 1 & & 20 & & & & & & 3 & 30 & 28.6 & 71.4 \\
\hline SBPC & 13 & & 1 & & 3 & 2 & 8 & 22 & 4 & 1 & & & & 5 & 59 & 56.2 & 43.8 \\
\hline CBPC & 16 & 2 & 2 & 5 & 2 & 3 & 21 & 25 & 7 & & & & & 5 & 88 & 83.8 & 16.2 \\
\hline C L & 2 & 1 & & 2 & 1 & & 2 & & & & & & & & 8 & 7.6 & 92.4 \\
\hline K $\quad \mathrm{M}$ & 16 & 2 & 3 & 6 & 3 & 4 & 26 & 27 & 7 & & & & & 8 & 102 & 97.1 & 2.9 \\
\hline $\mathrm{D} K \mathrm{~B}$ & 1 & & & & 1 & 1 & & 23 & & & & & & 2 & 28 & 26.7 & 73.3 \\
\hline T O B & 1 & & & & 1 & 1 & & 23 & & & & & & 2 & 28 & 26.7 & 73.3 \\
\hline MINO & 17 & 2 & 3 & 5 & 3 & 4 & 26 & 27 & 7 & & & & & 9 & 103 & 98.1 & 1.9 \\
\hline $\mathrm{A} \mathrm{m} \mathrm{K}$ & 4 & & & & 1 & 1 & 3. & 23 & & & & & & 2 & 34 & 32.4 & 67.6 \\
\hline LMOX & 9 & & 2 & 1 & 1 & 1 & 6 & 20 & 3 & 1 & & & & 3 & 47 & 44.8 & 55.2 \\
\hline C P Z & 4 & & 1 & & & 1 & 3 & 20 & 2 & 1 & & & & 3 & 35 & 33.3 & 66.7 \\
\hline $\mathrm{C} T \mathrm{X}$ & 11 & & 1 & 1 & 2 & 2 & 6 & 23 & 2 & 1 & & & & 6 & 55 & 52.4 & 47.6 \\
\hline C $2 x$ & 15 & 1 & 1 & 5 & 2. & 2 & 12 & 23 & 6 & 1 & & & & 7 & 75 & 71.4 & 28.6 \\
\hline
\end{tabular}

\section{表 2 薬剤に対する耐性数}

（1984年 2 月～1987年 1 月; 検体数 351 株）

\begin{tabular}{|c|c|c|c|c|c|c|c|c|c|c|c|c|c|c|c|c|c|}
\hline 䇚清群別 & A & & & & & & & $\mathrm{H}$ & & J & $\mathrm{K}$ & & & 㫘 & 計 & 㘗％ & \\
\hline \multicolumn{18}{|l|}{$\begin{array}{l}\text { 而惺数 } \\
\text { 菂剤各 }\end{array}$} \\
\hline G $\quad M$ & 4 & & & & 2 & 1 & & 35 & 4 & & & & & & 60 & \begin{tabular}{|l|l|}
17.1 \\
\end{tabular} & \\
\hline SB PC & 21 & 3 & 2 & 7 & 4 & 9 & 23 & 48 & 9 & 1 & & & & 10 & 139 & 39.6 & \\
\hline $\mathrm{CBPC}$ & 33 & 9 & 5 & 12 & 8 & 15 & 48 & 54 & 18 & & 1 & 1 & & 20 & 226 & 64.4 & \\
\hline $\mathrm{L}$ & $\sigma$ & 3 & & 2 & 2 & & 5 & 2 & 1 & & & & & & 18 & 5.1 & \\
\hline $\mathrm{M}$ & 43 & 20 & 8 & 16 & 16 & 15 & 88 & 69 & 31 & & & & & 28 & 338 | & 36.3 & \\
\hline $\mathrm{K} \mathrm{B}$ & 2 & & & & 1 & 1 & 3 & 39 & 4 & & & & & & 61 & & \\
\hline $\mathrm{OB}$ & 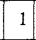 & 4 & & & 1 & 1 & 4 & 38 & 2 & & & & & & 60 & 17.1 & \\
\hline I NO & 37 & 13 & 7 & 12 & 14 & 16 & 72 & 58 & 18 & & & & & 22 & 271 & 77.2 & \\
\hline $\mathrm{m} \mathrm{K}$ & & & & & 1 & 1 & 9 & 38 & 1 & & & & & 5 & 62 & 17.7 & \\
\hline LMOX & 10 & 3 & 5 & 4 & 2 & 4 & 22 & 46 & 8 & 1 & & & & 12 & 128 & 36.5 & \\
\hline C P Z & 5 & 2 & 2 & 1 & 1 & 2 & 12 & 44 & 2 & 1 & & & & 4 & 77 & 21.9 & \\
\hline C T X & 19 & 4 & 2 & 6 & 4 & 5 & 22 & 48 & 7 & 1 & & & & 11 & 130 & 37.0 & \\
\hline $2 x$ & 34 & & & 13 & 6 & & & 5 & 1 & 1 & & & & 20 & 207 & 59.0 & \\
\hline
\end{tabular}

\section{表 4 薬剂に対する耐性数}

（1985年 2 月～ 1986 年 1 月, 検体数 103 株)

\begin{tabular}{|c|c|c|c|c|c|c|c|c|c|c|c|c|c|c|c|c|}
\hline 血清群別 & A & B & C & D & $\mathrm{E}$ & $\mathrm{F}$ & G & $\mathrm{H}$ & I & $\mathrm{K}$ & L 1 & & 型㶪能 & 計 & 堧\% & 咸％ \\
\hline \multicolumn{17}{|l|}{$\begin{array}{l}\text { 而性数 } \\
\text { 萎剂各 }\end{array}$} \\
\hline G $\quad M$ & & 3 & & & & & & 14 & 2 & & & 2 & 1 & 23 & 22.3 & 77.7 \\
\hline SBPC & 4 & 1 & & 1 & & 3 & 5 & 19 & 4 & & & 1 & 4 & 42 & 40.8 & 59.2 \\
\hline CBPC & 11 & 4 & 1 & 2 & 2 & 6 & 12 & 19 & 10 & 1 & & 2 & 13 & 83 & \begin{tabular}{|l|}
80.6 \\
\end{tabular} & 19.4 \\
\hline C L & 1 & 2 & & & & & 2 & 1 & 1 & & & & & 7 & 6.8 & 93.2 \\
\hline K M & 11 & 10 & 1 & 1 & 5 & 6 & 19 & 20 & 11 & & & 2 & 14 & 100 & 97.1 & 2.9 \\
\hline D K B & & 3 & & & & & & 14 & 2 & & & 2 & 1 & 25 & 24.3 & 75.7 \\
\hline $\mathrm{TOB}$ & & 3 & & & & & 3 & 14 & 1 & & & 2 & 1 & 24 & 23.3 & 76.7 \\
\hline M I NO & 11 & 8 & 1 & 2 & 4 & 6 & 17 & 18 & 7 & & & 2 & 13 & 89 & 86.4 & 13.6 \\
\hline $\mathrm{Am} \mathrm{K}$ & & & & & & & & 13 & 1 & & & 1 & 2 & 22 & \begin{tabular}{|l|}
21.4 \\
\end{tabular} & 78.6 \\
\hline LMOX & 5 & 1 & 1 & 1 & & 1 & & 19 & 4 & & & 1 & 6 & 45 & 43.7 & 56.3 \\
\hline C P Z & & 1 & & & & & & 19 & & & & 1 & & 24 & 23.3 & 76.7 \\
\hline $\mathrm{CT} \mathrm{X}$ & 2 & 1 & & & & & & 19 & 4 & & & 1 & 3. & 34 & 33.0 & 67.0 \\
\hline$C 2 x$ & 9 & 3 & & 2 & & & 10 & 20 & 8 & & & 2 & 9 & 66 & 64.1 & 35.9 \\
\hline
\end{tabular}

\section{表 6 病棟, 外来別集計表}

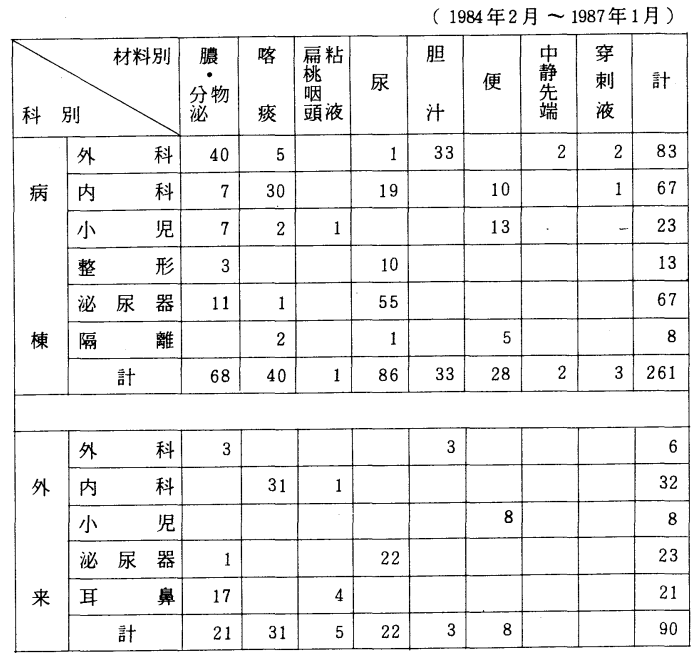


$\bigcirc$ 林田静枝, 長尾幸江

（厚生連広島総合病院細菌検查室）

\section{(目的)}

尿路感染症に打ける分離菌分布と薬凨感受性は, 施設の環境, 使用薬剂 などにより異なると言われているが, 当院においても第三世代セフェム系 抗生剤が採用され 5 年が経過した。同剤がその間の尿路感染症起炎菌に与 えた影響について検討するてとを目的とする。

(対象扔よび方法)

昭和 57 年 4 月 1 日 昭和 62 年 3 月 31 日までの 5 年間, 当細菌検查室に提 出された尿の定量培養により $10^{4} / \mathrm{ml}$ 以上検出されたすのを起炎菌とした。な お, 感受性検查には, 3 濃度ディスクを使用し, (H), (州), 感受性とし集 計, 同一人による同一菌種は初回成績を対象とした。

(結果と考察)

図1 1 当院における抗菌版購入量の年次推移である, 昭和 57 年第三七フ 土採用以来, 第一世代セフェムは激減し, 第二世代, 第三世代セフェム は増加傾向にある。表 1 は分離菌株の概要であるが, 外来では女性が 74.8 \%を占め, 入院では $54.2 \%$ で男女差は少ない。

次に尿路分離菌の頻度を図2 に示した。抗菌剂投与の可能性の少ない外 来では桿菌が $84.2 \%$, 中であ E. coli が $65.5 \%$ で年次変化屯少なかったの で外来菌株をまとめて表わした。入院では桿菌が平均 $69.8 \%$ 球菌が $26.1 \%$ で年次的に見ると第三世代セフェムが有効とされるProteus, Klebsiella，

Enterobacter 60 年度までは減少している,しかし, 減少していると言われ るSerratiaは当院では増加している。乙れは, 感受性率の低下が影響してい るものと思われる。(図3 ）な打，P. aeruginosaは第三世代に至っても抗菌力 が不充分であり，変化は少ない。

また, 球菌では外来ではStaphylococcus と Enterococcusが二分していたが, 入院 では第二世代セフェム, 第三世代セフェムに感受性率の低い Enterococcus が E.coli の次に多く分離され，功年次的飞も増加が目立った。

当院では多剤耐性のS. aureusの増加は見られなかった。

61 年度は過去 4 年間と多少パターンが変化し, E. coli, Enterococcus が減少 し, E. coli 以外の桿菌がそれぞれ増加している。てれは一時的なむのか, 最近使用されだしたニューキノロン郕などの影響か今後注目していきたい。 
( kg)

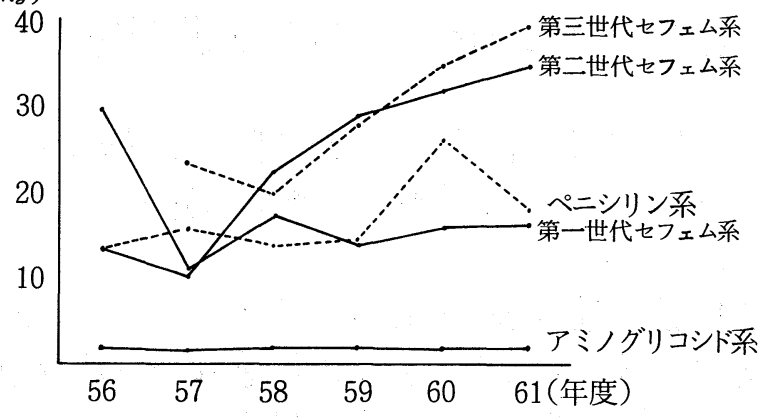

表 1 分離菌株の概要

\begin{tabular}{|c|r|r|r||r|}
\hline & 男性 & 女性 & 合計 & 分離株数 \\
\hline 外来 & 392 & 1164 & 1556 & 1579 \\
\hline 入院 & 380 & 450 & 830 & 892 \\
\hline 合計 & 772 & 1614 & 2386 & 2471 \\
\hline
\end{tabular}

図 1 抗菌剂購入量の年次推移 (注射剂)

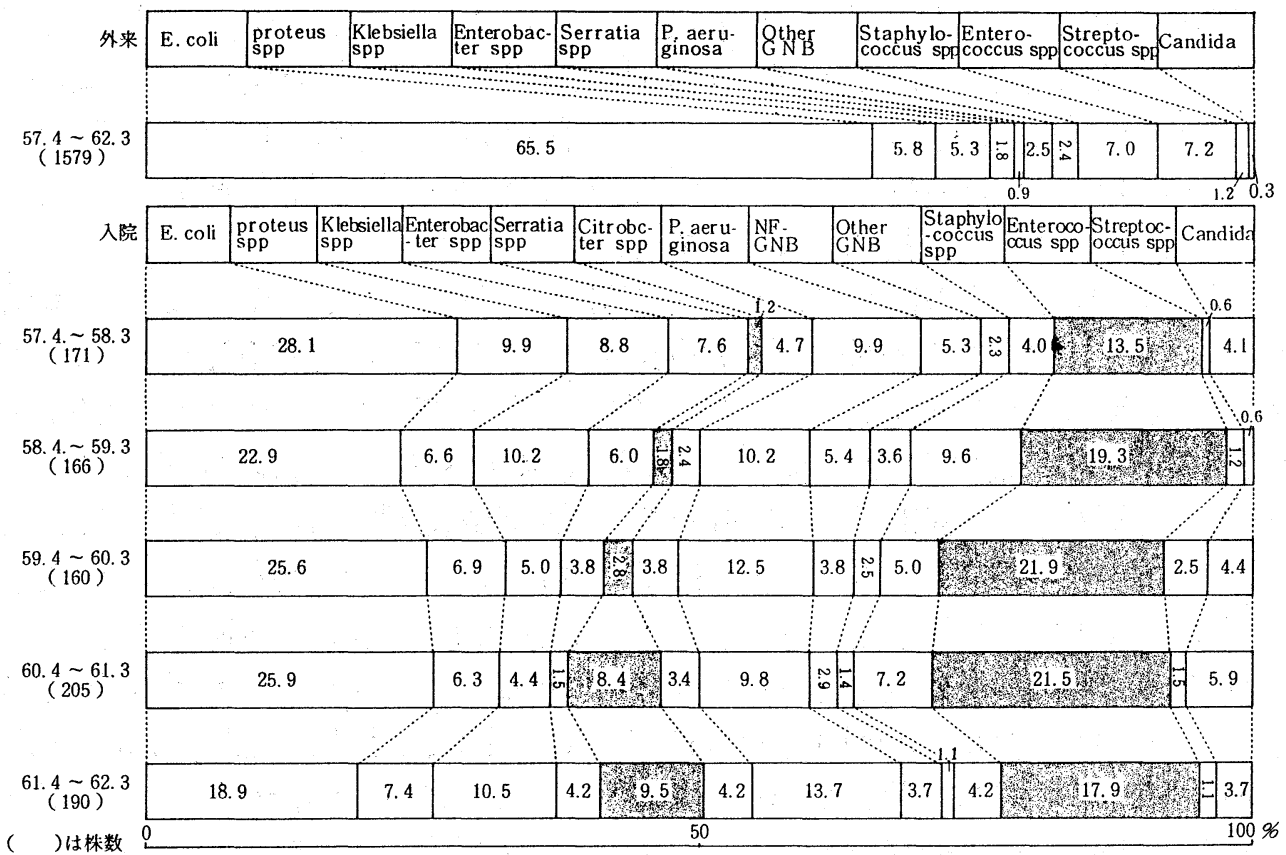

図2 尿路分離菌の頻度

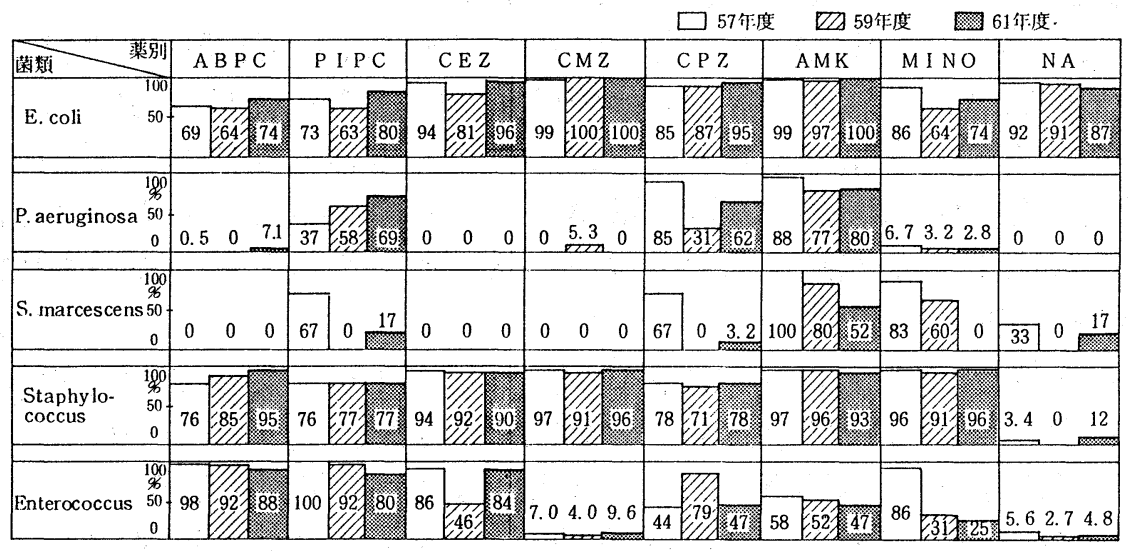

図 3 各種分離株の感受性年次推移 
514 当院臨床検査室におけるブドウ球菌 (ブ菌)の薬剂感受 性について

○掛布広行，大竹和行，住幸子，金子陽二，松永俊明 検査室グループ

（愛知・愛北病院）

（はじめに） S. aureus (S.A)は化膿性感染症を始め多くの感染症の原因 菌であり，また，コアグラーゼ陰性ブ菌（CNS）は日和見感染症の原因菌 として現在注目されている。ところで，1950年代に多く見られたぺニシリ ン耐性ブ菌感染症も，耐性ブ菌用ペニシリン，第一世代セフェム等の登場 により臨床的にその重要性は下降傾向にあった。ところが，近年 $\beta$ ラクタ 厶剂の多量消費と共に，これらの薬剂に耐性のブ菌感染症が増加傾向にあ るとの報告が多くなされている。そこで私達は，当院において臨床検体よ り分離されたブ菌全菌株に対して，13種の薬剤の感受性を測定し，それに 検討を加えたのでその結果を報告する。

（対象及び方法） 当院において昭和 61 年 7 月から 62 年 6 月までに細菌検 査室に提出された全ての検体より検出された全てのブ菌1072株についてコ アグラーゼ産生能及びマンニット分解性によって同定された S . A 664株と C N S 408株を対象にした。検体の由来は喀痰 380株，咽頭粘液 280株，尿 156 株，便 132 株，耳漏 34 株，眼脂 34 株，創傷膿 32 株，胵分泌物 13 株，その 他（裖瘡，血液，羊水，鼻汁等）11株であった。その全菌株について，コ ロニーより 1 白金耳採取した菌を $1 \mathrm{~m} l の$ 生理的食塩水に浮遊させ，その 1 白金耳を日水製薬の薬剂感受性用培地に接種して，それをガラス玉で全面 に拡げ，その培地面にABPC, DMPPC, MCIPC, CET, CEZ, CMZ, CTX, GM, Mino, ST, LCM, EM, Fomの13薬剤の昭和の 1 濃度ディスクを載せ, それを $37^{\circ} \mathrm{C} 18$ 時間培養後その阻止円の直経を測定し，換算表より（一） $(3+)$ に分類しその $($ 一) と $(+)$ を耐性 $(2+)$ と $(3+)$ を感受性とした。尚, ブ菌の分離率は S.A 10.5\%，C N S 6.5\%であった。

(結果及び考察) S.Aの各薬剤に対する耐性菌の比率は，図1，の左に 示したように, ABPC 23.3\%, DMPPC 22.4\%, MCIPC 8.5\%, CET 3.9 $\%, \mathrm{CEZ} 7.3 \%, \mathrm{CMZ} 5.4 \%$, CTX $4.5 \%$, GM 17.3\%, Mino 0\%, ST 0.3\%, LCM 22.1\%, EM 32.3\%, Fom 7.7\%という結果で, ABPC, DMPPC, GM, LCM, EM の 5 種で若干耐性化しているが，全体的に多くの 薬剂が有効と思われる。

C N S の各薬剤に対する耐性菌の比率は，図 1 。の右に示したように， ABPC 9.3\%, DMPPC 35.8\%, MCIPC 12.3\%, CET 0\%, CEZ 2.5\%, CMZ 2.5\%, CTX 2.0\%, GM 21.6\%, Mino 0.5\%, ST 4.9\%, LCM 16.2\%, EM 18.1\%, Fom 7.9\%という結果で, S. Aに比べると DMPPC が耐性化していたが，全体的に耐性株は少ないようである。 
ところが，DMPPC 耐性の菌株に限って集計すると，S.Aは図 2 . の左に 示すように, S. AはABPC $80.8 \%, \mathrm{MCIPC} 37.8 \%, \mathrm{CET} 17.6 \%, \mathrm{CEZ}$ $32.4 \%, \mathrm{CMZ} 24.3 \%$, CTX 20.3\%, GM 59.5\%, Mino 0\%, ST 1.4 \%, LCM 78.4\%, EM 81.0\%, Fom 20.6\%, CNS は右に示すように, ABPC 24.7\%, MCIPC 34.2\%, CET 0\%, CEZ 6.8\%, CMZ 6.8\%, CTX 5.5\%, GM 43.8\%, Mino 1.4\%, ST 9.6\%, LCM 27.4\%, EM $30.1 \%$ ，Fom 12.3\%という結果で，DMPPC耐性株は多くの薬剂にも耐性 化しており，有効と思われる薬剤もかなり少なくなっている。

そこで各菌株が幾つの薬剤に耐性化しているかを調べると，図 3 ．に示 すように，GM耐性株と比べると，S．A で3 薬剂までが少なくなっており DMPPC 耐性株の方が多剂に対して耐性化の傾向を示している。

（結び） DMPPCを中心に薬剤の感受性について検討した結果，これに耐 性の菌株はその多くが多剤に対して耐性の傾向をもち， $\beta$ ラクタ厶剂の使 用状況を考えると，この様な調査を継続して行い，常に耐性化や院内在住 細菌の状況を根気よく観察していかねばならないと考えられた。

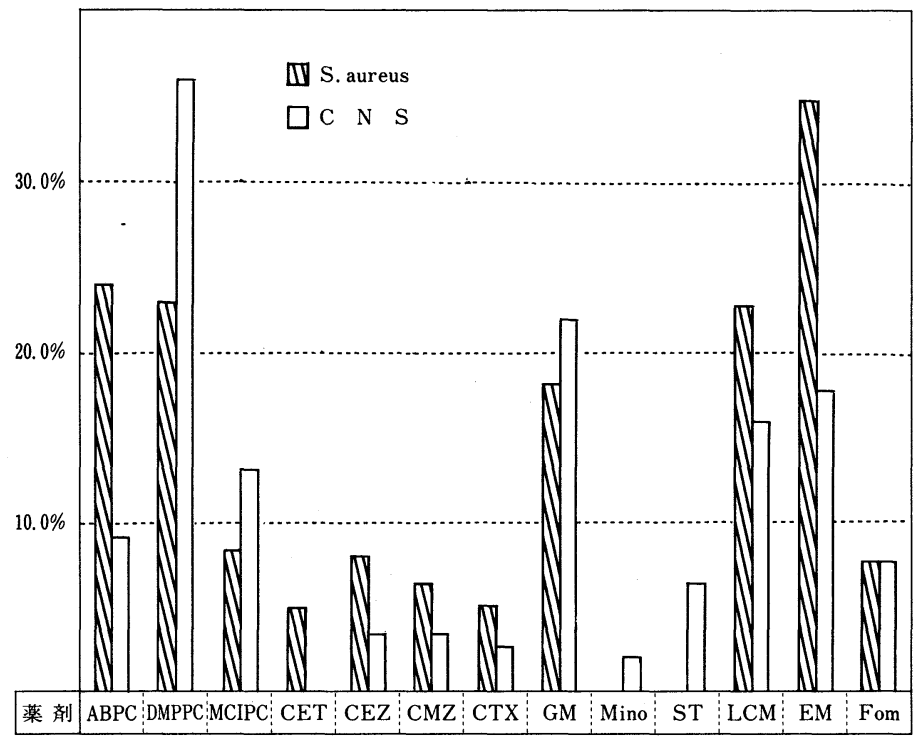

図 1.ブドウ球菌の薬剤耐性率

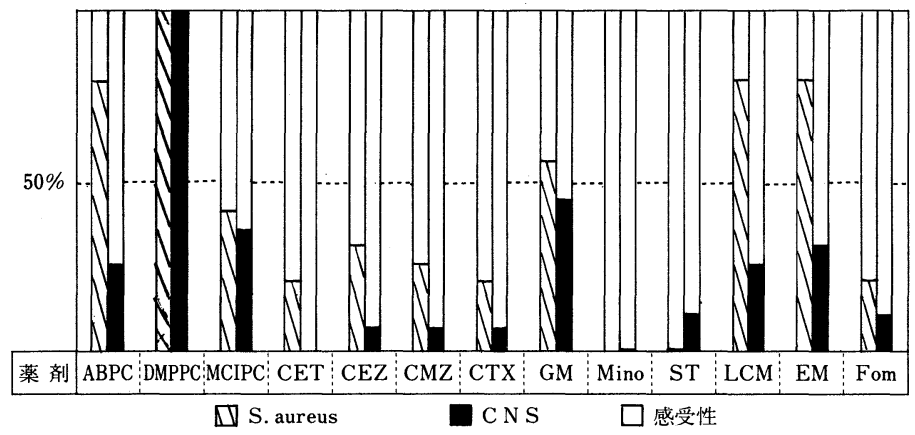

図 2. DMPPC耐性菌の薬剤耐性率

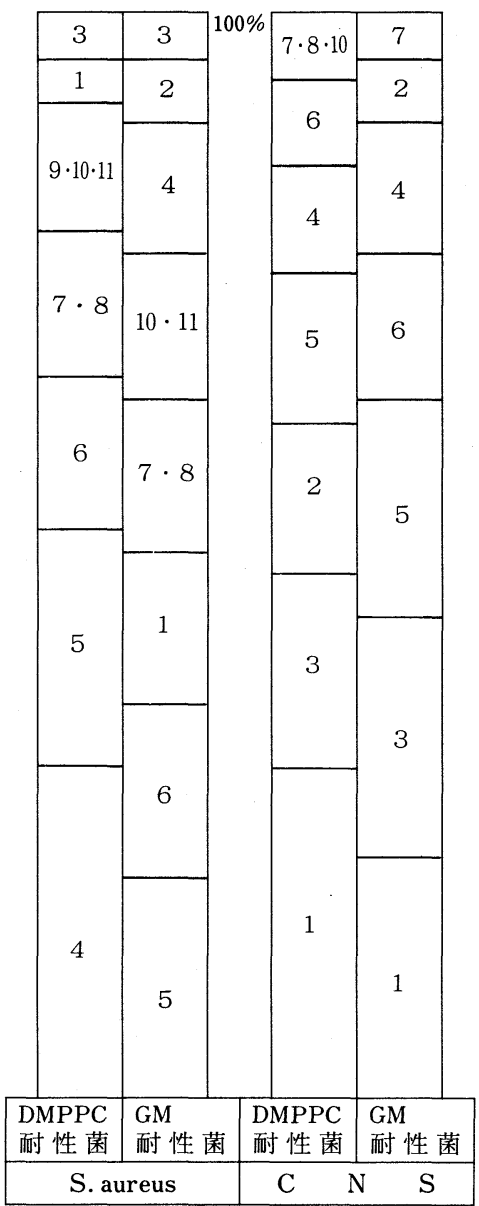

図 3. 耐性化薬剂数のDMPPC 及びGM耐性菌株の比較 


\section{$515 \beta$-ラクタマーゼの保有率}

萩原石夫（愛知県厚生連知多厚生病院中検）

$\begin{array}{lll}\text { 関島 } & \text { 和実 } & \text { 同 } \\ \text { 大岩 } & \text { 啓三 } & \text { 同 }\end{array}$

目的臨床細菌検査に於ける薬剤感受性の成績により、治療に抗生剤の 選択がなされている。多くの抗生剂のうちで最も広く汎用されている屯の は細胞壁の合成の阻害作用を有するぺニシリン系や、セフエム系などの $\beta$ 一ラクタム系抗生剂である。この抗生剂が多量に使用されているために、 多くの細菌が本来保有している $\beta$ - ラクタマ一ゼの産生量が増加し、 $\beta$ ラクタム系抗生剤が無効となり症状の改善がみられない。そこで、臨床分 離菌について $\beta$-ラクタマ一ゼの保有の有無を、試験濾紙法にて検討した ので報告する。

方法検出菌数は、喀痰 10 個、咽頭粘液 $5 \sim 6$ 個、鼻汁 $5 \sim 6$ 個、扁桃 粘 液 10 個、耳漏 $5 \sim 6$ 個、眼脂 $4 \sim 5$ 個、膿 $4 \sim 5$ 個、胆汁 20 個、尿 $10^{4}$ $\mathrm{CFU} / \mathrm{m} \ell$ 、胵分泌物 $5 \sim 6$ 個以上検出した菌株を対象とした。

$\beta$ ーラクタマーゼ検出用濾紙は、ニトロセフィン法とアシドメトリー法 (ペニシリン $\mathrm{G}$ 、セファゾリンを基質としたディスク)でディスクはシャ ーレー内に置き、PH7.0のP B S で適正に浸たるようしめした後、被検菌 をディスク上に接着させフタをし $2 \sim 3$ 分後に判定し更に 30 分後に再度判 定した。判定は写真に見られるようにニトロセフィン法は赤色の発色を、 アシドメトリー法は黄色の発色を陽性と判定した。その他の点については 使用書に準じた。感受性試験は一濃度ディスクを使用した。

成績表 1 は、菌種別に各方法を比較した表でニトロセフィン法（以下 $\mathrm{N}$ 法と略）の陽性率は $\mathrm{S}$ 。 aureus $74.6 \% \mathrm{~S}$. epidermidis $58.0 \%$ E. coli $82.4 \%$ K . pneumoniae $78.6 \%$ P . aeruginosa $95.0 \%$ H. influenzae $5.6 \%$ アシドメトリー法（以下 A 法と略）ペニシリナー ゼ（ P C ）は N 法、A法 P C 共に陽性は S . aureus $72.9 \% \mathrm{~S}$. epide rmidis $58.0 \%$ E. coli $19.6 \%$ K. pneumoniae $71.4 \%$ P. aer uginosa $30.0 \%$ H. influenzae $2.8 \%$ N 法とA 法セファロスポリナー ゼ（ＣＥ）共に陽性は E . coli $52.9 \% \quad \mathrm{P}$. aeruginosa $75.0 \% \mathrm{H}$. influenzae $2.8 \%$ の菌種であった。

感受性と $\beta$-ラクタマーゼについて比較したのが表 2 の $\mathrm{S}$. aureusは ABPCやSBPCよりあPIPCで+、一を耐性とするとA 法のP C が N 法 よりも多くみられたが、CCL、CET、CTM、FOMはほとんど同じ傾向 がみられた。E。coli は表3 に見られるように $\mathrm{N}$ 法と A 法 C E は PIPC と SBPC では同様の、七フェム系では $\mathrm{N}$ 法に A 法 C Eよりつよく出るよ うである。K． pneumoniae 表4は、 S B P C でN 法が強く他は同様にみら 
れた。表 5 の P . a eruginosa では N 法と、A 法 C E は共に同じような傾 向がみられた。H . influenzae は各方法共に同じ傾向であった。

結語 Staphylococcusは誘導型で、K. pneumoniae と共にペニシリ ナーゼを、E， coli と P. aeruginosaはセファロスポリナーゼ型の $\beta$ ー

ラクタマ一ゼを有する菌種である。 $\mathrm{N}$ 法は少量の $\beta$-ラクタマーゼにあ反 応するが、 $\mathrm{A}$ 法は特異性があるのでできれば 2 種類の方法を使用し、臨床 側に迅速に報告ができ抗生剂の選択の一助になると思われるので利用する ことを括すめします。最後に当院山田院長はじめ、各科部長先生や診療 の先生方のご協力を深く感謝します。

\begin{tabular}{|c|c|c|c|c|c|c|}
\hline \multirow{3}{*}{$\underbrace{}_{0}$} & \multirow{3}{*}{\multicolumn{2}{|c|}{$=r 0+>1+\infty$}} & \multicolumn{4}{|c|}{$r \geq k x+1)-a(1-c k, c k)$} \\
\hline & & & \multicolumn{2}{|c|}{$P C$} & \multicolumn{2}{|c|}{$c \varepsilon$} \\
\hline & & & & - & + & \\
\hline \multirow{2}{*}{$\begin{array}{c}\text { s. sureus } \\
\mathrm{N}-5,9 \\
\end{array}$} & + & 44 & 43 & 1 & 0 & 44 \\
\hline & - & 15 & 4 & 11 & 0 & 15 \\
\hline \multirow{2}{*}{$\begin{array}{r}\text { S. epidernidis } \\
x-30\end{array}$} & + & 29 & 29 & 0 & 0 & 29 \\
\hline & - & 21 & 4 & 17 & 0 & 21 \\
\hline \multirow{2}{*}{$\begin{array}{rr}8.6011 \\
\mathrm{~N}-3\end{array}$} & + & 42 & 10 & 32 & 27 & 13 \\
\hline & - & 9 & 0 & 9 & 2 & 7 \\
\hline \multirow{2}{*}{$\begin{array}{r}X \text {. pneueontae } \\
N-1\end{array}$} & + & 11 & 10 & 1 & 0 & 11 \\
\hline & - & 3 & 0 & 3 & 0 & 3 \\
\hline \multirow{2}{*}{$\begin{array}{r}P \text { serusinoss } \\
N-20 \\
\end{array}$} & + & 19 & 6 & 13 & 13 & 4 \\
\hline & - & 1 & 0 & 1 & 0 & 1 \\
\hline \multirow{2}{*}{$\begin{array}{r}H . \text { Influenzas } \\
\mathrm{N}-3\end{array}$} & + & 2 & 1 & 1 & 1 & 1 \\
\hline & - & 34 & 0 & 34 & 0 & $3+$ \\
\hline
\end{tabular}

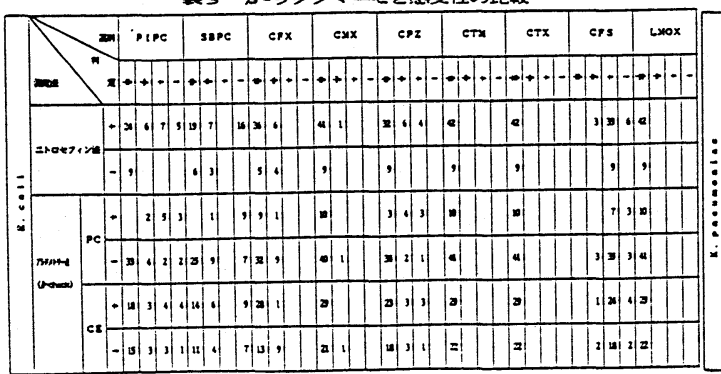

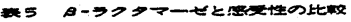
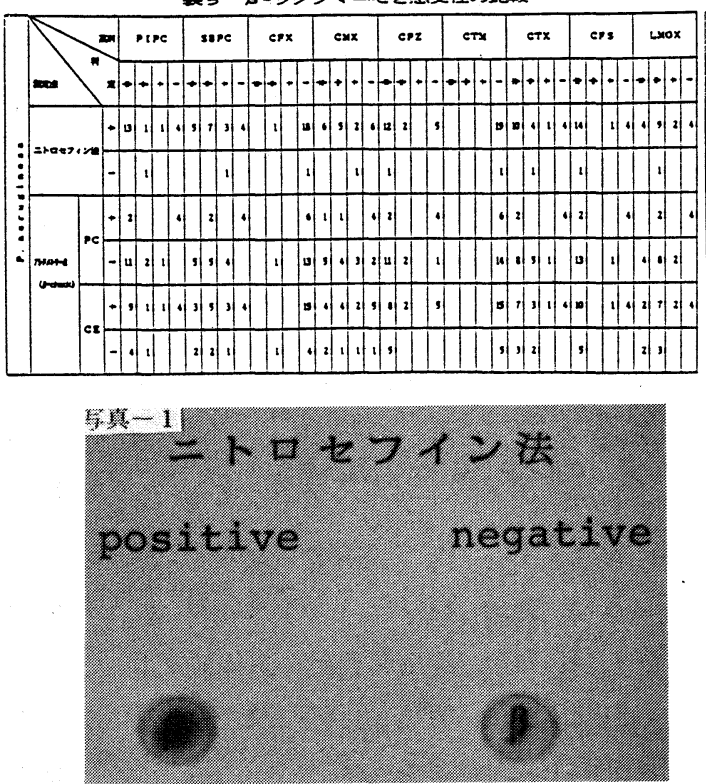
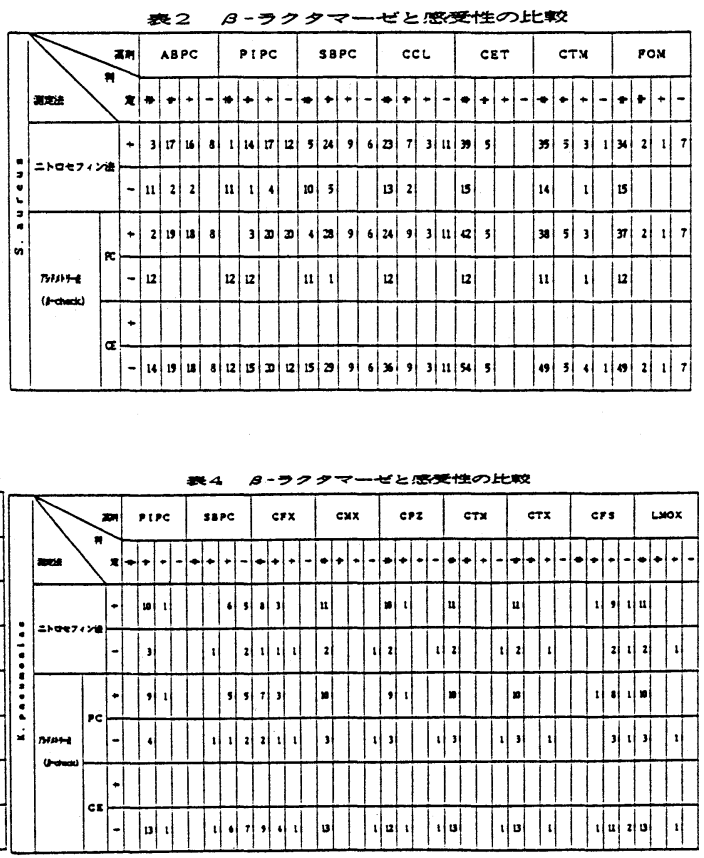

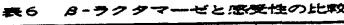
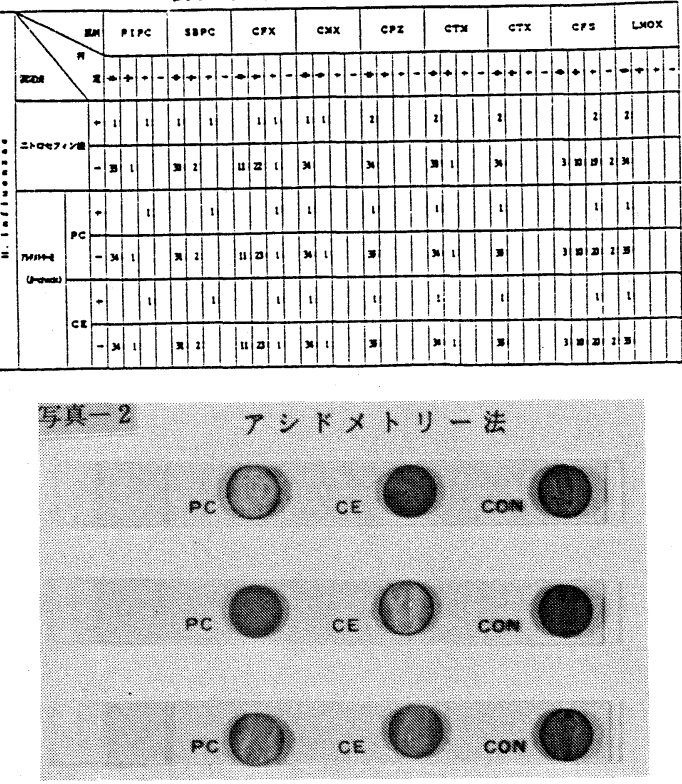


\section{6 当科に打ける皮膚細菌感染症の分離菌执よび薬剂感受性}

\section{$\bigcirc$ 安野 秀敏}

(山口県厚生連小郡第一総合病院皮膚科)

\section{原田律子（同院検查科）}

昭和 61 年 4 月より同 62 年 5 月までに、当科にて経験された皮膚細菌感染 症より分離できた細菌の種類、検出された黄色ブドウ球菌（以下、黄色ブ 菌）の薬片感受性および特異な症例について報告する。

表 1 には、分離菌の種類および分離株数を示した。菌が分離できたのは 76 症例で、総分離株数は 98 であった。分離株数では、黄色ブ菌が 54 と最あ 多く、次いで表皮ブドウ球菌が 13 ：溶連菌と緑膿菌が各々 10 と続き、大腸 菌が 4 、変形菌が 3 であった。黄色ブ菌は、76症例中 54 株、71\%に検出さ れ、現在であ皮膚感染症の多くは、本菌が原因であるととが確認できた。

表 2 には、分離できた 54 株の黄色ブ菌に対するぺニシリン系およびセフ エム系薬凨の感受性を(州、( $(+) 、(+) \sim(-)$ の 3 段階に分けて、その百分率を数 值で示した。（）内の数は、検査件数である。 $\mathrm{AB}-\mathrm{PC}$ は、検查 47 株中 11 $\%$ にしか(州がなく、現在検出される黄色ブ菌には、臨休的にほとんど効果 がないと思われた。 $\mathrm{AB}-\mathrm{PC}$ と MCI-PCの合剂である AB-PCsは、検查 53 例中 $100 \%$ に(州であり、MCI-PCは、まだ黄色ブ菌に対する感受性が良好 であり、この合剤の皮虞感染症に拈ける臨床的役割は顕著であると思われ た。CVA／PCは、AM-PC とCVAの合剤であるが、(州は78\%であり、黄色 ブ菌感染症に有用であると思われた。セフェム系抗生物質では、CEX、CFT CEZ はいずれあ(州が $60 \%$ 台で、耐性菌が増加しているように思われた。C C L は、(州が $45 \%$ と $50 \%$ を割っていて、黄色ブ球に対する抗菌力が著明に 低下してきていると思われた。てれは、最近のCCLの多用による結果かむ しれない。CMZは、(州が $87 \%$ で、非常に有用な抗黄色ブ菌剤であると思わ れた。CERは、(州が $77 \%$ であった。CETは、27症例にしか検查していないが その $96 \%$ に(卅) で、黄色ブ菌感染症に現在であ非常に有用な抗生物質である と思われた。

表 3 には、ペニシリン拈よびセフェム以外の薬剂の黄色ブ菌に対する感 受性を示した。C P は、(州が $52 \%$ 、(州が $46 \%$ で、以前より黄色ブ菌に対す る抗菌力は回復して打り、E M は、(州が $54 \% 、(+) \sim(-)$ が $46 \%$ と二峰性に解 離している結果が得られたが、これらは諸家の報告と一致する所見であっ た。このととは、C P の外用薬が、皮膚表在性黄色ブ菌感染症に対して、 現在であ有用であるととを示す所見であると思われた。MINOは、(州が 59 \%と、やや抗菌力が落ちぎみであると思われた。G $\mathrm{M}$ 打よび $\mathrm{AMK}$ は、(州が $40 \%$ 台で、耐性菌の増加が認められ、G M 外用薬の有用性は、以前より低 下していると思われた。FOMおよび $\mathrm{OFX}$ は、(州が $78 \%$ 扝よび $81 \%$ で、黄色 
ブ菌に対して良好な抗菌力を持つ薬剤であると思われた。

続いて特異な臨木例、(1)新生児膿痂疹、(2)足白癖の 2 次感染で、B - 溶 連菌が感染し、丹毒様?となった例、(3) D M の老人の膿痂疹様皮疹例、(4) 緑膿菌性趾間ビラン症について供覧する。

表 1 検出菌（76症例）

\begin{tabular}{|c|c|}
\hline 黄色ブドウ球菌 & 54 \\
\hline 表皮ブドウ球菌 & 13 \\
\hline 溶 連 菌 & 10 \\
\hline 緑 膿 菌 & 10 \\
\hline 変 形 菌 & 3 \\
\hline 大 腸 菌 & 4 \\
\hline その 他 & 4 \\
\hline 計 & 98 \\
\hline
\end{tabular}

表 2 黄色ブドウ球菌感受性（54例）

\begin{tabular}{|c|c|c|c|c|c|}
\hline & & $(+1+)$ & $(-1+)$ & $(+) \sim$ & $(-)$ \\
\hline$A B-P C$ & $(47)$ & 11 & 43 & 46 & $(\%)$ \\
\hline$A B-P C s$ & $(53)$ & 100 & 0 & 0 & \\
\hline $\mathrm{CVA} / \mathrm{PC}$ & $(46)$ & 78 & 22 & 0 & \\
\hline C EX & $(50)$ & 62 & 20 & 18 & \\
\hline C C L & $(20)$ & 45 & 30 & 25 & \\
\hline $\mathrm{CFT}$ & $(24)$ & 66 & 30 & 4 & \\
\hline $\mathrm{CEZ}$ & $(49)$ & 65 & 33 & 2 & \\
\hline $\mathrm{CMZ}$ & $(30)$ & 87 & 13 & 0 & \\
\hline C E R & $(22)$ & 77 & 23 & 0 & \\
\hline $\mathrm{CET}$ & $(27)$ & 96 & 4 & 0 & \\
\hline
\end{tabular}

※ A B - PC S : A B - P C とMC I - P Cの合剤

表 3 黄色ブドウ球菌感受性（54例）

\begin{tabular}{|ll|r|r|r|}
\hline & & (HI) & (H) & $(+) \sim(-)$ \\
\hline C P & $(46)$ & 52 & 46 & $2 \quad(\%)$ \\
E M & $(13)$ & 54 & 0 & 46 \\
M I N O & $(46)$ & 59 & 39 & 2 \\
G M & $(46)$ & 48 & 22 & 30 \\
A M K & $(47)$ & 45 & 51 & 4 \\
F OM & $(45)$ & 78 & 18 & 4 \\
O F X & $(41)$ & 81 & 17 & 2 \\
\hline
\end{tabular}


517 感染症での薬剤感受性について

○後藤元彰, 前田正雄, 大橋昭任, 金子陽二 薬剤科および検査科グループ

\section{〔はじめに〕}

（愛知・愛北病院）

感染症の起炎菌およびその薬剤感受性は各施設において若干差があると され，一方臨床の場においては結果が判明する以前に抗菌剤の投与される 場合が少なくない。今回我々は, 当院における薬剤感受性を調査し, 若干 の知見を得たので報告する。

〔対象および方法〕

昭和 58 年 4 月より昭和 61 年 12 月までに当院検查科において分離された主 要菌種について調査した。検体採取部位別にその分離菌を集計し, また薬 剂感受性試験の方法としては昭和ディスクを用い, ABPC, CBPC, SBPC, CEZ, CCL, CXM, CTX, LMOX, GM, DKB, EM, MINO, CP, FOM, NAの15種類について行った。なお感受性成績については州と\#の 臨床的に効果を示すと思われるものの頻度で示した。

〔結果と考察〕

今回の結果を検体別分離頻度および菌種別薬剂感受性として図に示す。

1. 咽頭・喀痰：咽頭ではグラム陽性菌は S. aureus と A 群 Streptococcus が $30.0 \%, 23.1 \%$ と高頻度で，グラム陰性菌は H. influenzaeが 18.6 \%検出された。喀痰では Staphylococcus 属が $49.6 \%$ と半数近く検出され, グラム陰性菌ではKlebsiella属とP. aeruginosa がともに10\%ほど検出され た。Staphylococcus属に対してはM I NO，CPがともに $90 \%$ 以上の感受性 を示したがその副作用を考えると，70\%以上の感受性を示す七フェム系薬 凨やアミノグリコシド系薬剤の方が有用であると思われる。A群 Streptococcusはペニシリン系およびセフェム系薬剤のいずれに対しても感受性が 良好であった。H.influenzaeは CEZを除くすべての薬凨に対し良好な感受 性を示したが，第一選択薬郕といわれている A B P Cに対しては $84.6 \%$ と 耐性菌が出現してきているのがわかる。

2. 尿：グラム陰性菌では E. coli が $25.5 \%$ と最も多く, グラム陽性菌 ではD群 Streptococcus が19.0\%検出された。E.coliに対しては抗菌力がよ く, しかも尿中への移行が比較的よい薬郕として A B P CやN Aが知られ ているが，今回の結果ではN A は64.4\%と耐性菌が出現してきているのがわかる。D群 Streptococcusに 対しては A B P Cが第一選択薬剂といわれているが，今回の結果でも 89.9 \%とよい感受性を示した。

3. 大便：グラム陰性菌ではKlebsiella属とCampylobacterが32.1\%, 
23. $0 \%$ で最も多く，グラム陽性菌ではD群 Streptococcus が16.7\%検出さ れた。Klebsiella属に対しては第三世代のセフェム系薬剂のCTX, LMOX が98.6\%，98.4\%と最もよい感受性を示した。Campylobacter に有効であ るといわれている E M, F O Mは $98.9 \% ， 89.5 \%$ とい感受性を示した。

4. 膿・裖瘡： Staphylococcus 属は膿 $55.7 \%$, 裖瘡 $54.3 \%$ と過半数を しめ，䙏瘡ではP.aeruginosaが22.6\%と高頻度であった。P.aeruginosaに は抗緑膿菌用アミノグリコシド系薬剂が有効であるといわれているが，今 回の結果からも G M 80.1\%，D K B 79.9\%とともによい感受性を示した。

5 . 眼脂・耳漏： 眼脂ではStaphylococcus 属が75. $3 \%$ と過半 数をしめ, 耳漏では S. aureus が38.7\%と最も多く，次いでH.influenzae 17.4\%，P. aeruginosa 17.0\%と検出された。Staphylococcus 属, P.aeruginosaに対し てはアミノグリコシド系薬剤がともによい感受性を示した。

\section{〔むすび〕}

感染症の化学療法は，大変信頼度の高い治療手段であることを考えると， 当院での臨床分離菌の各種薬剂に対する感受性の動向を日常的に把握して おくことはより的確な化学療法のために重要であることから，今後も調査 を続けていきたいと考えている。

検体別分離頻度および菌種別薬剤感受性

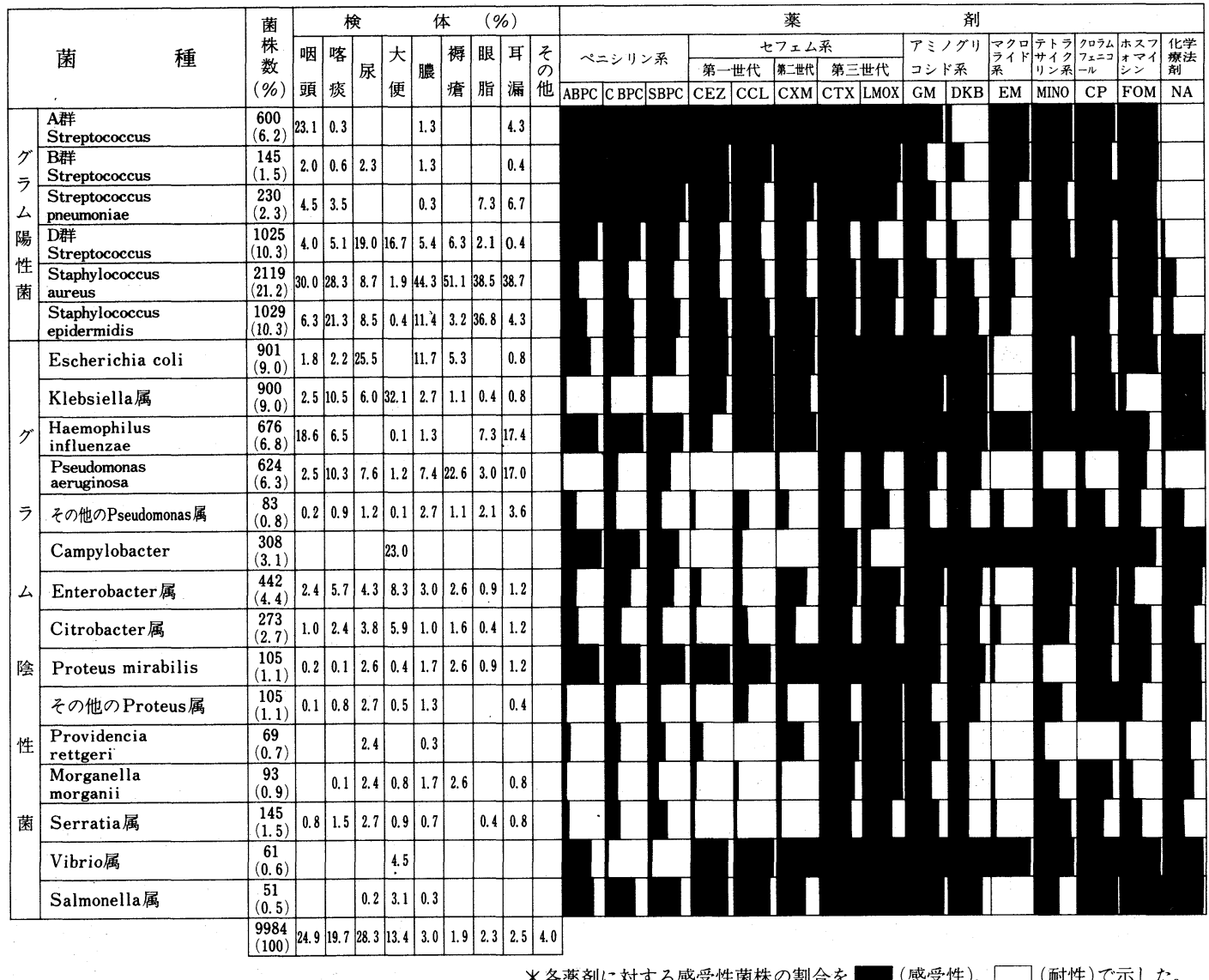




\section{泌尿器科疾患}

\section{1 健診血尿 573 例の臨床的検討}

石坂和博 石丸尚萩原明酒井邦彦（土浦協同泌尿 器科）田谷利光（同健康管理センタ一）石田義雄広 瀬 和夫（同放射 線 科 )

健康診断で指摘された尿潜血むしくは顕微鏡的血尿の精査目的で来院し た患者を集計し，若干の知見を得たので報告する。

〔対称及び方法〕昭和 59 年 1 月から 61 年 12 月までの 3 年間に当泌尿器科を 受診した 573 例を対象とした。腹部超音波検查を 396 例，IVP（経静脈的 腎孟造影）を 313 例，膀胱鏡を 83 例，尿細胞診を 47 例に施行した。疾患は 生命，尿路に対する影響，手術の必要性，血尿との関連から，高有意義， 中有意義，低有意義の 3 群に分け榆討した。

〔結果〕受信者の年齢は7 歳から 88 歳，平均 48.8 歳。女性 433 例，男性 140

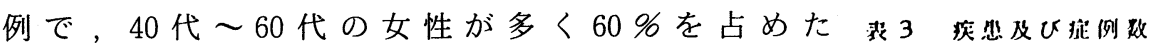

(表1)。昭和 60 年度の茨城県農業従事者検診 で尿潜血（+）以上を指摘された者は男性 4497 人中 $629(14 \%)$, 女性 12921 人中 3266 人 $(25 \%$ ）で女性に有意に高くなっている。（P<0.01） (表 2)。発見された泌尿器疾患は149例で受 診者の $26 \%$ にった（表 3 ）。高有意義疾患は 14 例で，うち悪性腫瘍 5 例，尿管結石 5 例， 蛋白尿高度で慢性系球体腎炎を疑った内科的 腎疾患 4 例であった。中有意義疾患 41 例では膀 胱炎之腎結石が多かった。低有意義疾患は94例 で, 腎囊胞, 腎下垂, カルンクルスが多かっ た。疾患の発見率を男女別で見てみると, 男 性 140 例中 48 例 (34\%) 女性 433 例中 101 例 (2 3\%)で有意に男性に高かった。(P<0.05)（表4）

\section{表 1 受診者の年龄分布}

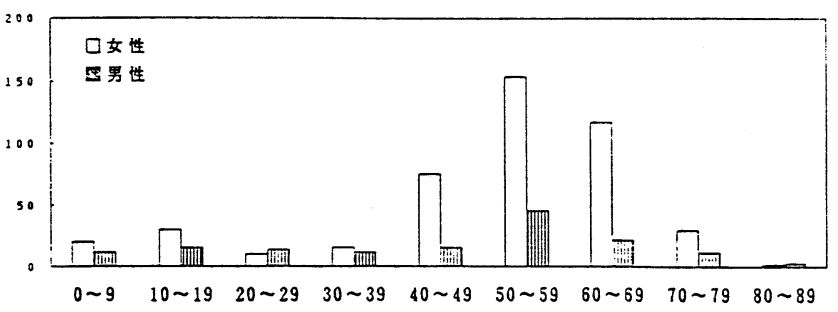

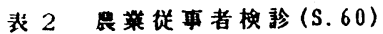

\begin{tabular}{|c|c|c|}
\hline & 男性 & 女性 \\
\hline 妾新证数 & 4497 & 12921 \\
\hline 血颀们り & $629(14 x)$ & $3266(25 x)$ \\
\hline
\end{tabular}

\begin{tabular}{|c|c|c|c|}
\hline 疾患名 & 解: 例数 & & \\
\hline & 推数 & 哆 & 女 \\
\hline 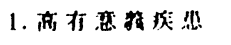 & $11(9.4 x)$ & 8 & 6 \\
\hline 胼脱的病 & $2(1.3 x)$ & 1 & 1 \\
\hline 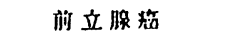 & $1(0.7 x)$ & 1 & 0 \\
\hline 督船 & $2(1.3 x)$ & 1 & 1 \\
\hline 尿管枯石 & $5(3.4 x)$ & 3 & 2 \\
\hline 内科的腎疾患 & $4(2.7 x)$ & 2 & 2 \\
\hline 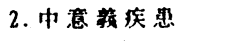 & $41(27.5 x)$ & 9 & 32 \\
\hline 腅 & $25(16.8 x)$ & 1 & 21 \\
\hline 枯石 & $13(8.7 x)$ & 8 & 5 \\
\hline 尿管狭怒 & $2(1.3 x)$ & 0 & 2 \\
\hline UVJ狭窈 & $1(0.7 x)$ & 0 & 1 \\
\hline 3. 低意翊疾忽 & $94(63.1 x)$ & 31 & 63 \\
\hline 点辛胞 & $36(24.2 x)$ & 15 & 21 \\
\hline 肾下垂 & $20(13.4 \%)$ & 0 & 20 \\
\hline 重複肾う尿管 & $7(4.7 \%)$ & 2 & 5 \\
\hline 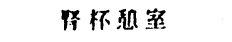 & $1(0.7 x)$ & 0 & 1 \\
\hline 前立腺肥大症 & $10(6.7 x)$ & 10 & 0 \\
\hline 疗管㿇 & $1(0.7 x)$ & 0 & 1 \\
\hline 传性湤立腺炎 & $2(1.3 x)$ & 2 & 0 \\
\hline 前立腺斯不 & $1($ ij. $7 x)$ & 1 & 0 \\
\hline 尿道カルンクルス & $14(9.4 x)$ & 0 & 14 \\
\hline 初邀狄第 & $2(1.3 \%)$ & 1 & 1 \\
\hline a. $1+2+3$ & 149 & 48 & 101 \\
\hline b. 暀数 & 573 & 110 & 133 \\
\hline c. $a / b$ & $26 \%$ & $34 \%$ & $23 x$ \\
\hline
\end{tabular}


高有意義疾患飞限っても男性 8 例 (5.7\%)，女性 6 例（1.4\%）で有意に男性に 高い（P<0.01）。血尿の程度を，赤血球 1 視野 1 個未満， $1 \sim 9$ 個，10個以上， 多数，に分けてみると， 3 群とも，軽度と考えられる 9 個以下が過半数を 占めた（表5）。高有意義疾患で多数が多いのは尿管結石例による所が大き い。検査別の異常発見率では，IVP $18 \%$, 腹部超音波 $12 \%$, 膀胱鏡 $2.4 \%$, 細胞 診 $0 \%$ であった（表6）。IVPでのみ異常所見が得られたすのは，尿管結石 4 例，腎結石 6 例などがある(表 7) 。腹部超音波でのみ異常所見が得られ たものは，膀胱腫瘍 1 例，腎癌 1 例，腎襄胞 29 例であった（表 8）。腫瘍患 者をまとめると（表 9 ), 膀胱癌 2 例，腎癌 2 例，前立腺 1 例，年齢は全例 50 歳以上であった。血尿は多数認めたのは膀胱癌の 1 例のみで，血尿なし が 3 例あった。腹部超音波は，血尿なく見落しかねない膀胱癌の 1 例を発 見し，また T 2 の腎癌症例む発見し，有効な検查であった。全例手術治療 が施行されているすのの，受診時既に骨転移を有し腎摘後 2 力月で死亡し

涪4明女比

\begin{tabular}{|c|c|c|}
\hline & 罗性 & 文性 \\
\hline 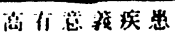 & $8(5.7 x)$ & $6(1.4 x)$ \\
\hline 中打它我疾患 & $9(6.4 x)$ & $32(7.4 x)$ \\
\hline 低管笔疾患 & $31(22.1 x)$ & $63(14.5 x)$ \\
\hline 就 & $48(34 x)$ & $101(23 x)$ \\
\hline 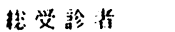 & 140 & 433 \\
\hline
\end{tabular}

表 5 血尿の程度

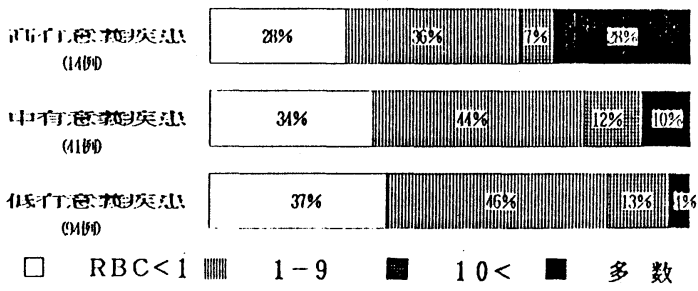

表 6 查項目别買常発見率

\begin{tabular}{|c|c|c|c|c|}
\hline 娭查項目 & IVP & Echo & 脱镜 & 稩胞診 \\
\hline 罪常所見 & 53 & 46 & 1 & 0 \\
\hline 㴔施行数 & 313 & 396 & 83 & 47 \\
\hline 発屺涞 & $18 x$ & $12 x$ & 2. $4 x$ & $0 x$ \\
\hline
\end{tabular}
た腎癌症例ああり, 必ずしあ早期発見につ ながっているとは言えなかった。

更に健康診断を充実させるととあに，血 尿軽度の症例であ積極的検索が必要と考え られた。

\begin{tabular}{|c|c|c|c|c|c|c|c|c|c|}
\hline 性 & 年路 & 坅断名 & 血尿 & IVP & Echo & その他 & TNM & 泊模 & f位 \\
\hline N & 54 & 胼缕 & $(-)$ & - & + & & TaNOMO & TUR & 6M後趾 \\
\hline $\mathbf{F}$ & 77 & 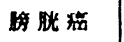 & 多数 & & & 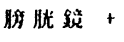 & TINONO & 㬹胧企摘 & 8MIK B \\
\hline M & 55 & 满 & $(-)$ & - & + & & T 2 NOMO & 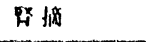 & 13NIt 趾 \\
\hline 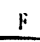 & 59 & 知 & 怪 & + & + & & T3 NOMI & 桴摘 & 2M洨死 \\
\hline M & 70 & 肳立腺娬 & $(-)$ & & & 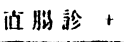 & T $3 N 2 M 0$ & 前立䠌全摘 & 4M传 趾 \\
\hline
\end{tabular}

\begin{tabular}{|c|c|c|c|}
\hline 的管枮石 & 4 & 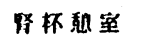 & 1 \\
\hline 敢桔石 & 6 & 尿管港 & 1 \\
\hline 牧下话 & 20 & 前立期斯石 & 1 \\
\hline 些找路了 & 5 & & \\
\hline
\end{tabular}

表8Echo所見のみ異常なしの

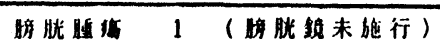

䞍 1

草胞 29 
○市川晋一（仙北組合泌尿器科）五十嵐卓（同内科） 木津典久（秋田組合病院泌尿器科）

鈴木隆志、能登宏光 ( 秋田大学泌尿器科)

はじめに

最近、超音波診断装置の進歩と普及により超音波検査による集団検診が 行われるようになった。泌尿器科領域でも、これまで秋田大学と関連病院 は、経腹壁的超音波断層法を用いた前立腺集団検診を施行してきた。今回 私たちは秋田県仙北地区において対象臓器を広げて腎、膀胱、前立腺集団 検診を行い、その有用性を検討したので報告する。

対象および方法

昭和 61 年 7 月から 11 月にかけて、対象は秋田県仙北地区の神岡町、中仙 町、千畑町の3 地区（図1）の一般住民のうち希望者で、原則として50歳 以上の男女である。方法はあらかじめ配付したパンフレット（図２）と裏 面の問診票に解答してもらい保健婦による再確認の後に、検尿（蛋白、糖、 潜血）と泌尿器科医師が経腹壁的超音波検查と前立腺の触診を施行した。 超音波検查は、膀腅に尿を充満させた被検者を仰臥位として、3.5 $\mathrm{MHz}_{\mathrm{z}}$ をた は $5 \mathrm{MH}_{2}$ セクタ走查型探触子を恥骨上部に置き、膀脱と前立腺の横断面と縦 断面を観察した（図了）。次に左右肋骨弓下で両則腎の横断面と縦断面を 観察し、適宜腹臥位や背部を追加し、3.5 $\mathrm{MH}_{\mathrm{z}}$ リニア走査も併用した。画像 はビデオレコーダーとポラロイドフィルムに記録した。一人当たりの検査 時間は約 5 分であった。超音波検査や前立腺触診や尿検査で異常が認めら れた者は要精検者として二次検診に当科や近くの病医院に紹介した。

結果

一次検診受診者は3 町合わせて396名で、要精検者数は 102 名 (25.8\%) であった。実際に二次検診を受けたものは73名（18.4\%）で（表 1 ）、要精 検者の $71.6 \%$ あっった。集団検診のシステム（図4）に沿った二次検診（ 表 2 ) では、疾患の重複を含めて主な腎疾患 25 例、尿管疾患 1 例、膀脱疾 患 2 例、前立腺疾患 44 例、その他 13 例、このうち膀脱癌 2 例、前立腺癌 1 例が発見された。また異常の認められなかった者は6名であった。

考察

私たちはこれまでの経腹壁的超音波断層法を用いた前立腺集団検診を拡 大して腎、膀胱などの検診を行いその有用性を検討した。その結果全受診 者 396 名のうち二次検診で 85 例の異常を認め、膀脱癌 2 例、前立腺癌 1 例 の癌 $(0.76 \%)$ 発見できた。このように経腹壁的超音波断層法を用いた尿路 集団検診は、受診者に苦痛を与えず簡便で効率良いスクリーニングであり、 受診しづらい泌尿器科疾患の発見に有用であると思われた。 
図1集検実施地区

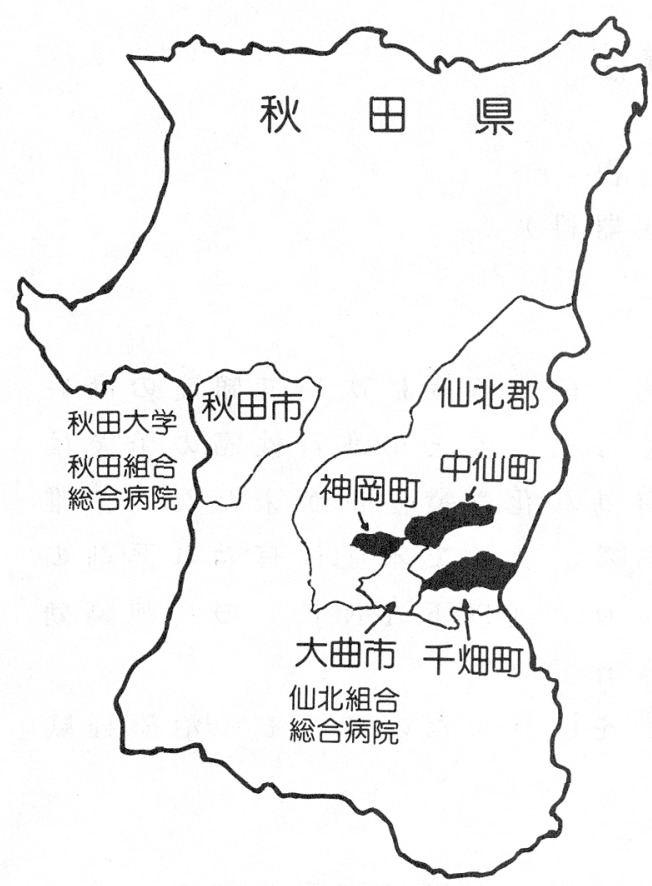

図2 集検パンフレット

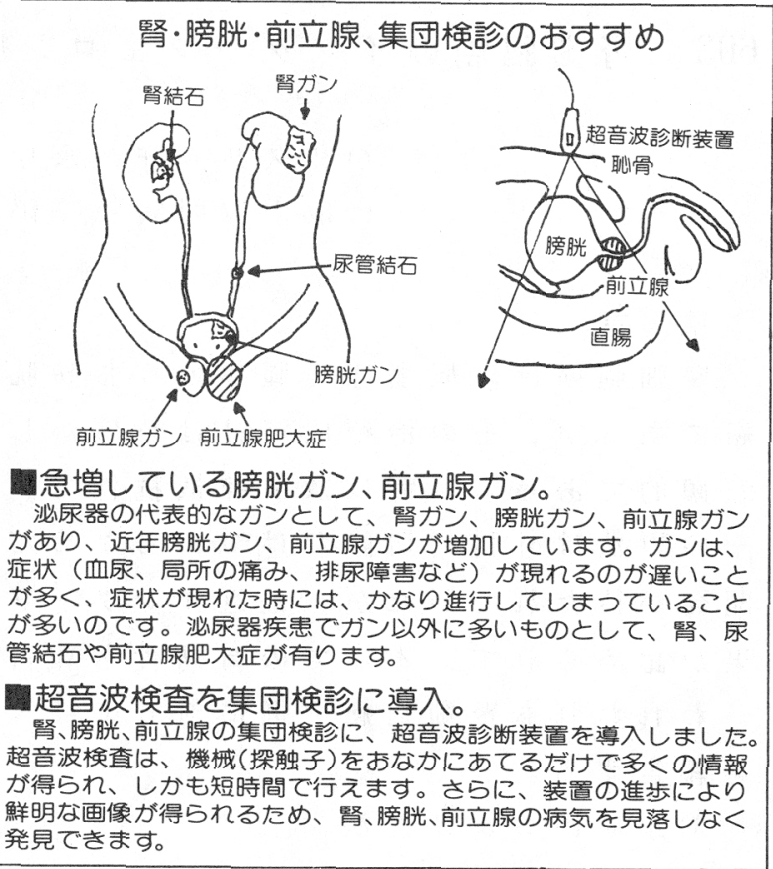

図3 経腹壁的超音波断層法

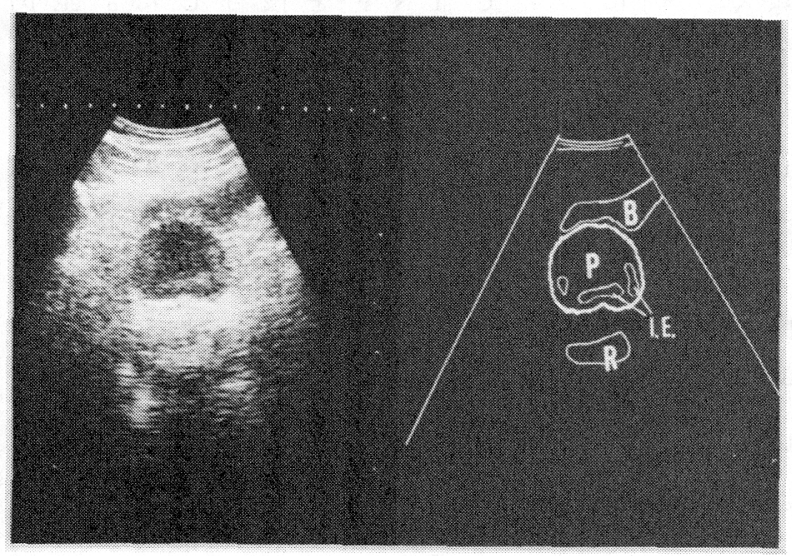

図4集検システし

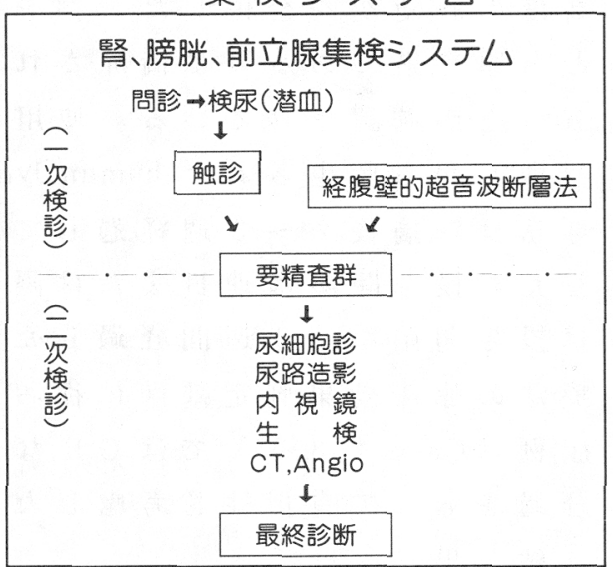

表 1

\begin{tabular}{|c|c|c|c|c|c|c|c|}
\hline \multirow{2}{*}{ 秋田県仙北郡 } & \multicolumn{2}{|c|}{ 神岡田 } & \multicolumn{2}{|c|}{ 中仙町 } & \multicolumn{2}{|c|}{ 干畑田 } & \multirow{2}{*}{ 計 } \\
\hline & 男 & 女 & 愚 & 女 & 男 & 女 & \\
\hline \multirow[b]{2}{*}{ 一次検診受診者数 } & 69 & 54 & 57 & 25 & 97 & 94 & \multirow[b]{2}{*}{396} \\
\hline & \multicolumn{2}{|c|}{123} & \multicolumn{2}{|c|}{82} & \multicolumn{2}{|c|}{191} & \\
\hline \multirow[b]{2}{*}{ 要 精 検 者 数 } & 23 & 12 & 22 & 3 & 36 & 6 & \multirow[b]{2}{*}{$\begin{array}{c}102 \\
(25.8 \%)\end{array}$} \\
\hline & \multicolumn{2}{|c|}{$\begin{array}{c}35 \\
(28.5 \%)\end{array}$} & \multicolumn{2}{|c|}{$\begin{array}{c}25 \\
(30.5 \%)\end{array}$} & \multicolumn{2}{|c|}{$\begin{array}{c}42 \\
(22.0 \%)\end{array}$} & \\
\hline \multirow[b]{2}{*}{ 二次検診受診者数 } & 15 & 5 & 21 & 3 & 24 & 5 & \multirow[b]{2}{*}{$\begin{array}{c}73 \\
(18.4 \%\end{array}$} \\
\hline & \multicolumn{2}{|c|}{$\begin{array}{c}20 \\
(16.3 \%)\end{array}$} & \multicolumn{2}{|c|}{$\begin{array}{c}24 \\
(29.3 \%)\end{array}$} & \multicolumn{2}{|c|}{$\begin{array}{c}29 \\
(15.2 \%)\end{array}$} & \\
\hline
\end{tabular}

表2

二次検診結果

\begin{tabular}{|c|c|c|c|c|c|}
\hline & & 神岡町 & 中仙田 & 干畑田 & 計 \\
\hline 腎囊 & 胞 & 3 & 5 & 4 & 12 \\
\hline 腎 & 石 & 2 & 4 & 1 & 7 \\
\hline 水 & 腎 & 3 & & & 3 \\
\hline 胞 & 腎 & 1 & 1 & & 2 \\
\hline 結 & 核 & & & 1 & 1 \\
\hline 尿＼cjkstart管＼cjkstart結 & 石 & & & 1 & 1 \\
\hline 膀＼cjkstart胱 & 癌 & & 1 & 1 & 2 \\
\hline 前立腺肥大 & 症 & 9 & 13 & 18 & 40 \\
\hline 前 立 腺 結 & 石 & & 2 & 1 & 3 \\
\hline 前＼cjkstart立＼cjkstart腺 & 癌 & & & 1 & 1 \\
\hline の & 他 & 6 & 2 & 5 & 13 \\
\hline \multicolumn{2}{|l|}{ 計 } & 24 & 28 & 33 & 85 \\
\hline 常 & & & 2 & 4 & 6 \\
\hline
\end{tabular}




\section{3 腎細胞癌のインターフェロン療法}

\section{○和久井守, 永松秀樹}

(取手協同病院泌尿器科)

緒 言

腎細胞癌は泌尿器悪性腫瘍のうち膀胱癌, 前立腺癌飞次いで頻度の高い 癌であるが, その治療成績ははかばかしくなく，ととに進行性癌の予後は 悲観的である。本症は放射線抵抗性で, 有効な化学療法剂が未だなく, 唯 一の方法は外科的切除だけであるためである。そてで本症に有効な薬剤の 開発が待たれていたが, 最近インターフェロン（以下 I N F ) の抗腫瘍効 果が認められて, 本症での有効性あ報告されている。

われわれあ腎細胞癌 7 例に対してINFを投与したので, その治療経験 を報告する。

対象症例および方法

1986 年 1 月から 1987 年 5 月まで当院で治療した腎細胞癌 8 例のうち， 高度の肝硬変を合併した 1 例を除く 7 例について I N F を投与した。全例 とも原発巣である腎は摘除されていて, 病理学的に renal cell carcinoma であ るととが確認されている。使用した I N F はヒトリンパ芽球細胞（ナマル バ株) から産生された human lymphoblastoid interferon（H L B I )の $\alpha$ 型で，投 与法は腎摘後 2 〜 週経過してから 1 回 300 万または 600 万単位を筋肉注射 した。投与間隔は連日または隔日として最低 24 回以上投与した。効果判定 は投与開始から4週間経過した時点で, 厚生省小山・斉藤班による癌化学 療法の臨床効果判定基準に従った。測定可能または評価可能病変を有する 症例（Case 1，3，5）では C R ないし P D と判定できたが，他の例では臨床 経過をむって有用性を考慮した。

結果

HLBIを投与した 7 例の臨床的背景とH L B I 投与状況，効果の程度を Table 1 亿示した。転移巣が評価病变である 3 例では, Case 1 で H L B I 投与 開始 1 週後に肺転移巣が消失して, 4 週間以上維持されたので C R と判定 した。骨転移の 2 例はP D と判定した。各々 7 - 8 ケ月後に原発癌死して いる。評価病変のない例では, Case 3, 4 が腎摘後それぞれが 14 ケ月，12 ケ 月経過していて遠隔転移や局所再発がなく現在 disease freeと考えている。 Case 6, 7 は術後日屯浅く評価は保留としたい。副作用についてはTable 2 に 示した。最大の副作用は全身倦急感と食欲不振で,このため投与を中止せ ざるを得なかった 2 例があった。他の副作用は一時的ないし軽微なあので 投与を中止する程ではなかった。

次に C R と判定したCase 1 を呈示する。Case 1 O.C. 55 歳男性。上腹部 
不快感がありエコ一で検查中に偶然，右腎腫瘤を発見されて当科に紹介さ れた。術前検查で胸部断層撮影で背面から $9 \sim 10 \mathrm{~cm}$, 右肺 S 6 に $2 \times 1 \mathrm{~cm}$ の結節陰影で認めた。胸部 C T 同様の所見であった。腎動脈造影で hypervascular massを確認して右腎動脈塞栓術を施行した。1986年1月31日，右 腎摘を行い，術後 2 週目からHLBI600万単位を連日で開始した。 2 月 20 日の胸部断層撮影で転移巣は線維性に萎縮していてHLBI開始 4 週後には 消失して C R と判定した。HLBI は合計 600 万単位 $\times 52$ 回使用して，その後 $\mathrm{UFT}$ 内服を継続して現在に至るが転移巣の出現はなく disease free と評価 している。転移巣の消失がH B I にるあのか, 原発巣摘除後の自然退縮 によるあのか不明であるが，HLBIの効果発見は通常20回以上の投与が必 要であるととから後者によるあのであろうと考えている。

まとめ

腎細胞癌の治療は, 従来の化学療法や放射線療法では有効率はせいぜい $10 \%$ 程度であるのに比べて，INFでは 7 ～30\%の有効率が報告されており， 今後は手術後の第一次選択療法になると予想される。INFの効果発現は, 早い症例で 20 回投与後から遅いあのは60回投与後から出現するととああり, 有効性の判定は60回以上の投与後が妥当といわれているが, 副作用や経済 的理由で継続投与できないととああり今後の課題であある。またどのよう な症例に有効なのかについてもはっきりしていないが, 一般に性，年齢， 腫瘍の大きさには関係がないとされている。転移巣では肺に有効例が多く, 骨では無効なととが多いといわれ，われわれの例であ同様であった。さら に原発巣の Grade では low grade に有効例が多いとの指摘ああるが, high gradeに効果があるとの考えああり一定していない。INFは今後，解決すべ き課題は多いが, 腎細胞癌に対する有力な薬剂になると考えられる。

以上, 当院に扣ける腎細胞癌のINF療法の経験について報告した。

Table 1 Patient clinical characteristics

\begin{tabular}{|c|c|c|c|c|c|c|c|c|c|c|}
\hline \multirow{2}{*}{\multicolumn{2}{|c|}{ Case }} & \multirow[b]{2}{*}{ Sex } & \multirow[b]{2}{*}{ Age } & \multirow[b]{2}{*}{$\begin{array}{l}\text { PS } \\
(\%)\end{array}$} & \multirow[b]{2}{*}{ Histopathol ogy } & \multirow[b]{2}{*}{ Metastases } & \multicolumn{3}{|c|}{$\alpha-$ HLB I Therapy } & \multirow[b]{2}{*}{$\begin{array}{c}\text { Prognosis } \\
\text { (mos) }\end{array}$} \\
\hline & & & & & & & $\begin{array}{c}\text { Total Doses } \\
\text { (milion units } \\
\times \text { days })\end{array}$ & $\begin{array}{l}\text { Duration of } \\
\text { Therapy (wks) }\end{array}$ & $\begin{array}{l}\text { Tumor } \\
\text { Responce }\end{array}$ & \\
\hline 1 & o.c. & $\mathbf{M}$ & 55 & 100 & $\begin{array}{l}\mathrm{pT}_{2} \mathrm{~b} \mathrm{~N}_{0} \mathrm{M}_{\mathrm{c}} \\
\mathrm{GII} \text {, clear }\end{array}$ & Lung & $600 \times 52$ & 11 & $\mathrm{CR}$ & Alive (16) \\
\hline 2 & N.T. & $\mathrm{M}$ & 44 & 100 & $\begin{array}{l}\mathrm{p} \mathrm{T}_{2} \mathrm{aN} \mathrm{N}_{\mathrm{M}} \\
\mathrm{GII}, \mathrm{granular}\end{array}$ & - & $300 \times 24$ & 4 & $\begin{array}{l}\text { *not } \\
\text { evaluable }\end{array}$ & Alive (14) \\
\hline 3 & T.K. & $F$ & 53 & 40 & $\begin{array}{l}\mathrm{pT} \mathrm{T}_{2} \mathrm{bN}, \mathrm{M}_{1} \\
\mathrm{GI}, \quad \text { clear }\end{array}$ & Bone & $300 \times 36$ & 6 & $P D$ & Dead ( 8 ) \\
\hline 4 & Y.S. & $\mathrm{M}$ & 76 & 80 & $\begin{array}{l}\mathrm{pT}_{2} \mathrm{bN}_{0} \mathrm{M}_{0} \\
\mathrm{GII}, \quad \text { clear }\end{array}$ & - & $600 \times 24$ & 4 & $\begin{array}{l}\text { not } \\
\text { evaluable }\end{array}$ & Alive (12) \\
\hline 5 & I.C. & $M$ & 69 & 50 & $\begin{array}{l}\mathrm{pT}_{2} \mathrm{bN}_{1} \mathrm{M}_{1} \\
\mathrm{GWI} \text {, anaplastic }\end{array}$ & ic Bone & $600 \times 25$ & 4 & PD & Dead (7) \\
\hline 6 & M.T. & $\mathrm{M}$ & 48 & 100 & $\begin{array}{l}\text { pTs NoMo } \\
G I \text {, clear }\end{array}$ & - & $600 \times 45$ & 12 & evaluable & Alive (4) \\
\hline 7 & M.M. & $M$ & 61 & 100 & $\begin{array}{l}\mathrm{pT}_{2} \mathrm{bN}_{1} \mathrm{M}_{0} \\
\mathrm{GII}, \text { clear }\end{array}$ & - & $600 \times 24$ & 6 & $\begin{array}{l}\text { not } \\
\text { evaluable }\end{array}$ & Alive (2) \\
\hline
\end{tabular}

Table 2 Side effect of HLBI

\begin{tabular}{ll}
\hline General fatigue & 6 \\
Anorexia & 5 \\
Fever Eariy & 7 \\
$\quad$ Late & 1 \\
Leukopenia $(<3000 \approx)$ & 7 \\
Thrombocytopenia $\left(<10^{4}-1\right)$ & 1 \\
Liver dysfunction & 7 \\
Depression & 1 \\
\hline
\end{tabular}


604 超音波装置による腎体積の推定

○遠藤利男，皆葉茂夫，渡辺史夫，堤利明（取手協同 放），岩本均（同，内），和久井守（同，泌）

(はじめに)

従来より腎臓の計測については C T による断面積積算法, X 線フィルム による長径と短径の評価等, 種々の報告がなされていますが、いづれあ操 作が煩雑であったり，2 次元の情報のみで信頼性に欠けたりの短所があり ます。又超音波（以下 U S と略）による計測あ長径と短径, 断面積との比 較で体積についての報告は少ない。今回当院ではコンベックス型プローベ を用いて面積及び体積が計測できる超音波装置が導入されましたので，そ の性能を試験し正常腎の計測に応用して，C T の断面積積算法との相関を 調べましたので報告します。

（使用装置及び基礎試験）

使用機種はアロカ6 5 ア 0 で，乙の装置は円及び楕円の断面積とその $360^{\circ}$ 回転体としての体積を表示するモードが付いています。基礎試験として， 水槽に脱気水を入机た風船を沈め上からUSにて計測し, 実際の值と比較 した。又同様に粘土で種々の回転楕円体を作り計測した。その結果体積モ 一ドでは, 球形で平均 $-8.2 \%$, 回転楕円体では $+16.5 \%$ の誤差があった。し かし腎のようにやや偏平な楕円体では $+65 \%$ - $32 \%$ と誤差が大き過ぎて 実用に耐えないと考えられた。

\section{(対象)}

本年 1 月より 6 月まで当科で U S と C T を同日に施行した患者で腎尿路 系に異常を認めない42 例を無作為に抽出し，正常腎の体積としてそれぞ れU S と C Tで実测し比較した。

\section{(方法)}

対照としたのは東芝 $\mathrm{T} C \mathrm{~T}-70 \mathrm{~A}$ を使用してマルチフレームメニュー のスライスワイズ方式で体積を演算 しその横断体積の積算値を総体積と した。又US の計測は図 1 の如く, 腹臥位にて背部より $1 \mathrm{~cm}$ 毎の横断面 積を積算して総体積とする積算法と 図 2 の如く同じ体位で長軸方向の最 大断面像之それに直交する横断方向 の最大断面像より, 長径a, 横径 $b$ 厚径cを求め，乙れらを最大径とす
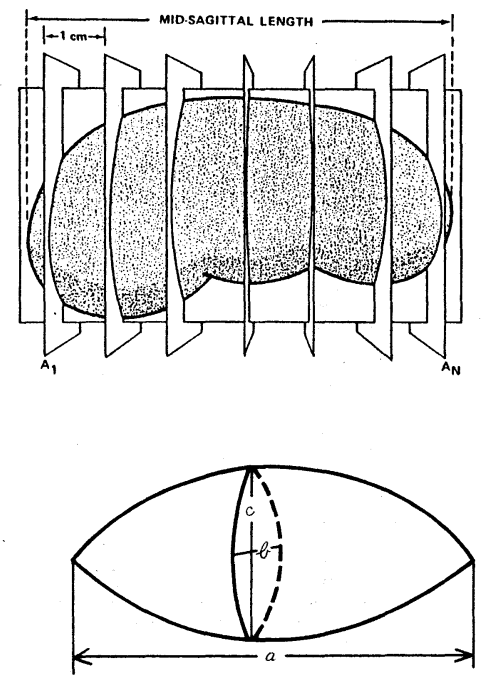

図 2 
る回転楕円体と考え次式より算出した。又横断面の形が著しく異なり，相 似形とみれない場合はその前後を数断面とり補正した近似值計算法をした。 体積 $=\frac{4}{3} \times \pi \times \frac{a}{2} \times \frac{b}{2} \times \frac{c}{2}=0.697 \times a \times b \times c$

\section{( 結果)}

本邦成人の腎の大きさは平均で 長径 $10 \mathrm{~cm}$, 横径 $6 \mathrm{~cm}$, 厚径 $4 \mathrm{~cm}$ と記載されているが, 今回の U S による計測では平均で右腎はそれ ぞれ $10.9 \mathrm{~cm} \pm 1.4 \mathrm{~cm}, 5.6 \mathrm{~cm} \pm 0.6 \mathrm{~cm}$ $4.5 \mathrm{~cm} \pm 0.7 \mathrm{~cm}$ であり左腎は $11 \mathrm{~cm} \pm$ $1.3 \mathrm{~cm}, 5.8 \mathrm{~cm} \pm 0.7 \mathrm{~cm}, 4.4 \mathrm{~cm} \pm 0.7 \mathrm{~cm}$ で長径でやや大きく，横径でやや 小さ目の結果であったが、母集団 が小さい為の誤差範囲内と思われ る。又 C T によ体積は平均で右 腎で $169.6 \mathrm{~cm}^{3}$, 左腎で $177.1 \mathrm{~cm}^{3}$ で あり，U S の積算法では $169.9 \mathrm{~cm}^{3}$ と $177.1 \mathrm{~cm}^{3}$ で, 相関系数む $\boldsymbol{\gamma}=0.9$ 644 と非常に良い相関が得られた。 又 U S による近似値計算法では, $196.4 \mathrm{~cm}^{3}, 207.6 \mathrm{~cm}^{3}$ で $r=0,9633$ と前者に比べ悪かった。

\section{(考察)}

U S の体積計測で我々が行った

表 1. 積算 法

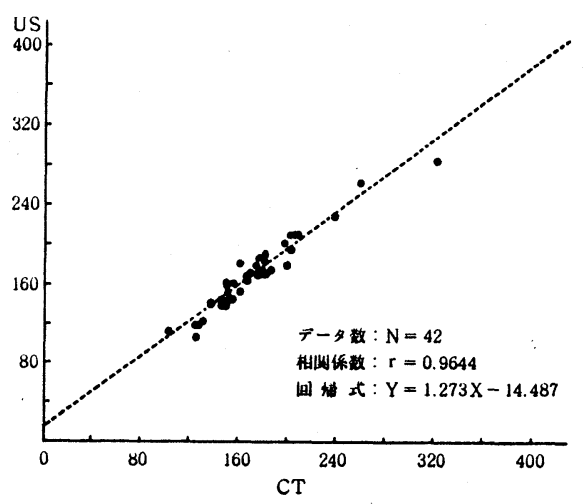

表 2. 近似值計算法

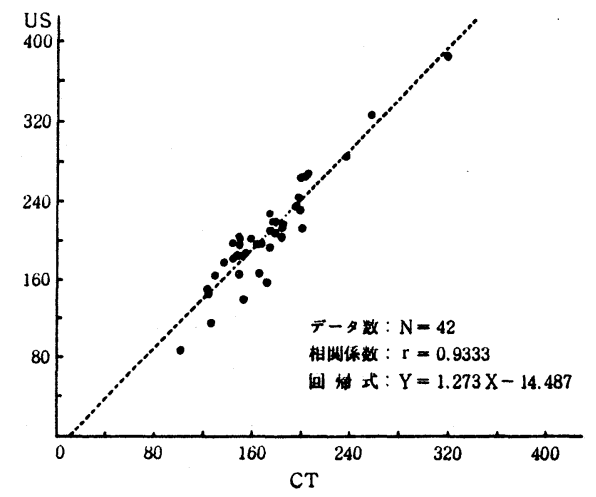

積算法はC T Tそれに匹敵する精度が得られた。本法はX線被曝のない点 反復検查の容易な点から慢性腎不全等の各種腎疾患の腎体積の経時変化の 追跡に応用できると思われる。又 U S による近似值計算法は前者が両腎で 20 断面以上必要なのに比べ, 4 - 8 断面で斉み, 呼吸の影響む少ない利点 があり，バラッキは多いあのの，その主因は横径/厚径比にあり，乙れが

1 に近くなる程 $\mathrm{C} \mathrm{T}$ 值との相関が増すようで, これからデータを集めて, 腎の形状分類をし補正定数により精度を上げたいと思います。

(まとめ)

正常腎の体積を C T と U S で比較したが, U S で充分対応できる事が, わかった。今後は本法で各種腎疾患に対象を広げ, 性差, 年齢差, 腎機能 との関係にあ分析を加えたいと思います。 
木村房枝前田千代子佐藤幸子佐々あや子

宮崎裕中村久(高萩協同病院、泌尿器科)

〔はじめに〕排泄性尿路造影は尿路疾患の診断に広く利用されている。特に点 滴静注腎孟造影法（以下 D I P と略す）は、比較的簡単な手技で、腎孟、 尿管、膀胱の鮮明な像が得られ、臨木診断上、極めて有用である。

しかし、造影率による副作用す $5.3 \%$ から $18.3 \%$ の頻度で出現すると言 われている。当院であ、泌尿器科新設によって、造影剂による副作用に遭 遇する機会が多くなってきた。

私たちは看護の立場から、当科に打ける D I P の副作用について検討し たので報告する。

〔対象及び方法]当科で昭和 61 年 9 月から 62 年 6 月までに、D I P を施行 した 162 例を対象とした。162 例の内訳は男性 97 例、女性 65 例、年齢分布 は13才から85才まで、平均年齢50.3才であった。

患者の不安を除くため、検查内容に対する十分な説明を行い、患者が安 心して検查を受けられるようにエ夫した。薬物過敏、ヨード過敏、アレル ギ一性疾患、心疾患、高血圧、糖尿病、腎疾患、痛風、てんかん等の既往歴にっ いて問診し、全員にヨードテストを施行した。ヨードテストは、添付アン

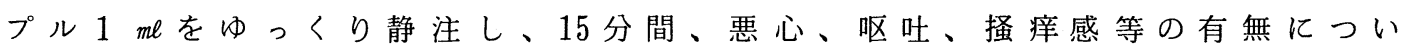
て観察した。ヨードテスト陰性例にのみ D I P を施行した。

造影剤には、イソペーク $280 \mathrm{R} 100 \mathrm{m \ell}$ を約 15 分かけて点滴静注した。検查 中は話かけを行い、患者をリラックスさせるように配慮しながら、検查開 始前より終了時まで、血圧、脈拍を測定し、全身状態を観察した。注射針 は注入開始後より、30分くらいまで留置して打き、緊急時に対処できるよ うに静脈を確保した。

[結果〕今回の調查でなんらかの副作用症状がみられたあのは、 162 例中 66 例、全体の $40.7 \%$ であった。乙れは軽度な反応む副作用として記載した ため、諸家の報告よりあ多くなったあのと思われる。

年齢別に副作用発現頻度を検討すると、20才代が $56 \% 、 40$ 才代が $52 \%$ で 青壮年層にやや多い傾向が認められた。

既往歴として、アレルギー性疾患を有する群とそうでない群にわけて副 作用の出現頻度をみると、それぞれ、 $42.6 \% 、 39 \%$ るあり、アレルギー性 疾患を有する患者では若干高頻度であった。

今回の調查で認められた副作用は顔のほてり感27例、発疹、じん麻疹21例、掻痒感 24 例、流涙、結膜充血 9 例、その他 16 例であった。諸家の報告と比較して、 呕気、呕吐の少ないのが特徵的であった。また、これらの副作用は注入直 
後に起こるとは限らず、出現時期は一定しなかった。私たちの調查例の中 には死亡は1例あなかったが、造影剂投与 30 分後に、ショックをきたした 1 例を経験したので呈示する。

症例 44 才、女性

主訴は顕微鏡的血尿、既往歴として食物アレルギーを認めた。健診で顕 微鏡的血尿を指摘され、61年 9 月 21 日当科を受診し、精查のため D I P を 施行した。造影剤注入開始より13分後、顔のほてり感、じん麻疹が出現し た。20分頃より、呕気あり、血圧下降がみられた。30分後、ショック状態 となったが、補液、昇圧剂の投与で 5 分後には回復した。

この症例においても、検查中血圧、脈拍を 5 分ごとに測定し、状態の変 化を観察していたととで、医師への報告及び、救急処置を敏速に行うこと が出来た。

また、この例のように、副作用反応が投与開始時より遅れて出現するて とああり、注射針はなるべく長時間留置して、血管を確保しておくことが 重要と思われた。

[まとめ]

1162 例中 66 例、全体の $40.7 \%$ になんらかの副作用症状がみられた。

2 青壮年層の副作用発現頻度がやや多くみられた。

3 アレルギー性疾患を有する群はそうでない群より副作用出現頻度が高 かった。

4 副作用症状の内容では、顔のほてり感、発疹、じん麻疹、掻痒感、流 涙、結膜充血が多く出現した。

5 副作用出現時期は一定せず、30分屯経過してからショック状態になっ た例があった。

6 患者の状態を詳細に観察し、重篤な副作用に対して、常に充分な対策 を講じておくことが、看護の立場からあ大切だと思われた。 
606 非イオン性造影剤による副作用の調查

岩田照夫, 結束満穂, 土浦協同病院 放射線科
鶴見紀男伊藤信夫
同
酒井邦彦石坂和博
同
泌尿器科

はじめに: 従来, 広く一般に用いられているイオン性造影剂は, 高浸透 圧性, イオン毒性, 化学毒性なよ゙の因子が造影剂の副作用の主たる要因と 考えられている。乙れに対し，非イオン性造影であるIopamidol（図工）は 従来の造影剤に比べ，副作用が少く，安全性に優れ，満足すべき造影能を 有していると報告されている。今回, 我々は, 排泄性腎孟造影を対象とし て主に安全性についての検討を行った結果，臨床的に優れていると確認さ れたので報告する。

\begin{tabular}{|c|c|c|c|}
\hline 商品名 & イオパミロン 300 & イオパミロン 370 & 一般名 lopmidol \\
\hline$\exists$ ヨド含有量 $(\mathrm{mg} / \mathrm{ml})$ & 300 & 370 & \multirow{5}{*}{ 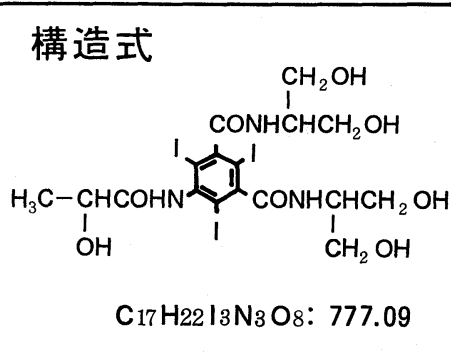 } \\
\hline 粘稠度 $\left(37^{\circ} \mathrm{C} \mathrm{cp}\right)$ & 4.4 & 9.1 & \\
\hline 比重 $\left(37^{\circ} \mathrm{C}\right)$ & 1.328 & 1.405 & \\
\hline $\mathrm{PH}$ & $6.5 \sim 7.5$ & $6.5 \sim 7.5$ & \\
\hline 浸透圧比 & 約 3 & 約 4 & \\
\hline
\end{tabular}

図1 Iopamidol の物 理化学的性質

対象と方法：対象は，昭和 61 年 8 月より昭和 62 年 3 月までの 8 ケ月間に 当科で I opamidolを使用し排泄性靔孟造影を行った 477 例（男性 266 例，女 性 181 例) で，年令は男性 0.6 才 89 才（平均 49.8 才）女性 0.5 才 84 才（平 均 48.7 才）であった。対象者の性, 年令分布を図 2 に示す。

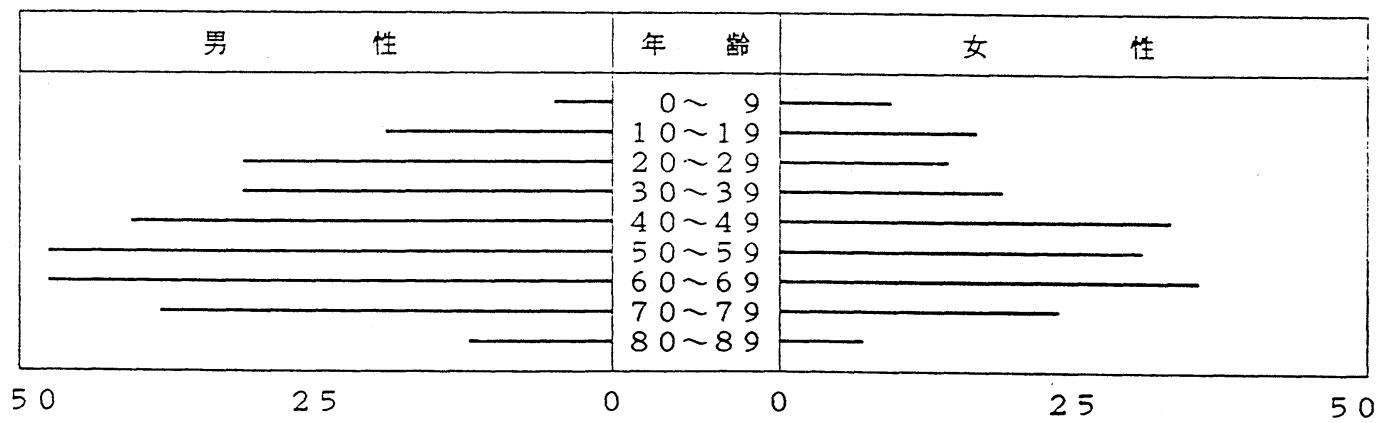

図 2 性, 年 令分 布

Iopamidol の投与方法は, テストアンプル $1 m \ell$ 静注によるヨード過敏反応 テスト後, 成人の場合 $1 \mathrm{VP}$ で $40 \mathrm{ml}$, DIP $100 \mathrm{ml}$ ，幼児は年令に応じて体重 $1 \mathrm{~kg}$ 当り $0.7 \mathrm{ml}$ を原則として前腕静脈内投与を行った。副作用の調查につい ては問診，観察，本人の訴えにより記録した。調查用紙は（表1）に示す。 
表 1 調查用紙

\begin{tabular}{|c|c|c|c|c|c|c|c|c|c|c|c|}
\hline \multirow{2}{*}{ 作 嗣 } & \multicolumn{2}{|c|}{ 性: 陫 } & 矁 & 笨 & \multicolumn{2}{|c|}{ 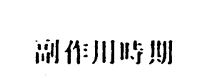 } & \multirow{2}{*}{ 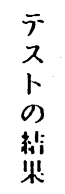 } & \multirow{2}{*}{ |iI) } & \multirow{2}{*}{ 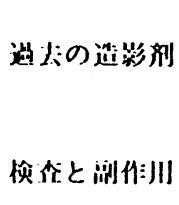 } & \multirow{2}{*}{$\begin{array}{c}\text { アレルキ- } \\
\text { の从容 }\end{array}$} & \multirow{2}{*}{ 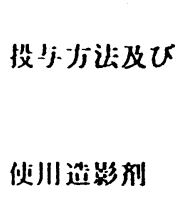 } \\
\hline & 哭 & 从 & 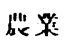 & 非茄品箖 & 投紧中 & 投. $\cdot j \cdot$ 後 & & & & & \\
\hline
\end{tabular}

結果: 造影施行 447 例のうち 2 例 ( $0.44 \%$ ) 飞副作用が認められた。 内容は治療を必要としない軽度な悪心（男性 41 才）と呕吐（男性 29 才）の みであった。またアレルギ一歴を有する者は11例（表 2 ），447例中過去 に 132 例がイオン性造影検查を経験し，14例（10.6\%）に副作用が認めら れたが（表 3 ），今回の調査では両群とも副作用の発現が認められなかっ た。

表 2 アレルギー内容

\begin{tabular}{|ll|}
\hline アレルギー内容 & \\
\hline 魚貝類 & 3 \\
薬剂 & 4 \\
果実（梅） & 1 \\
肉類 & 1 \\
寒冷しんま疹 & 1 \\
卵黄 & 1 \\
\hline
\end{tabular}

まとめ：排泄性腎孟造影に打ける副作用の発現頻度は治療を必要としな い軽度な反応を 447 例中 2 例に認められたが，過去のイオン性造影検査で は959 例中 157 例 ( $16.4 \%$ ) に認め, 治療を必要とした重篤な副作用も2 例認められている。前回の調查結果と比較しても安全性に優れているとと が示唆された。また造影効果む診断上有用であり満足すべき結果を得た。 


\title{
607 佐久総合病院における脊㖪損傷患者の排尿管理につんて
}

\author{
$\bigcirc$ 加藤 晴朗, 田中正敏, 平林直樹
}

(長野県・佐久総合病院)

脊蹃損傷患者ヶアの中で、腎機能保護を目的とした排尿管理は予後を左右する 因子として重要である。今回われわれは慢性期春損患者の排尿管理と問題点につ を検討した。

〔対象叔び方法〕1963年より、当院泌尿器科で排尿管理を行なっている慢性 期春損患者和上び春損にて同整形外科退院後の患者 40 名に、排尿に関するアンヶ 一ト調査て、30名分の返答を得た。このアンケートと検査結果を参考に患者の排 尿管理と問題点につらてまとめた。年齢は15〜79歳で、男性 27 名，女性 3 名であ る。受傷後の経過年数は 2 年から 22 年であった。アンケートの内容は、(1)排尿様 $\begin{array}{lllll}\text { 式について } & \text { (2) 尿意の有無 } & \text { (3)会陰部痛覚の有無 } & \text { (4) 尿失禁の種類について }\end{array}$

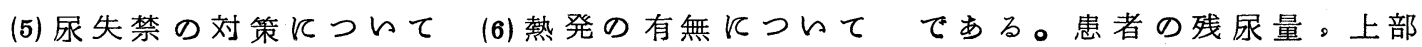
尿路の変化, 腎機能, 尿水力学的検査などを参考にした。

〔結果〕排尿様式に関しては、自然排尿 3 人,下腹部を押さえてむCrede法が 13人。下腹部をたたいたり、会陰部をつねるひきがね排尿が7人，間歇的自己導尿 法が 5 人，カテーテル留置例が 1 例，失禁によるるのが 1 例である。核上型と核 ・核下型に分けて検討すると核上型ではひがね排尿が13名中 7 名と多く、核・ 核下型では17名中12名が Crede法により3名が間歇的自己導尿法である（表1)。 尿意に関しては、会陰部の痛覚が保たれている患者では良好である。会陰部の痛 覚が保たれている15名中 13 名で弱いながらす自然の尿意を感じるてとがでをる が、会陰部の痛覚のないすのは15名中 1 名のみに自然の㽷意がみられ、11名が下 腹部のはり感や痛みにより尿意を感じ、核上型の了名は発汗。動悸などの交感神 経の緊張で尿意を感じる（表2）。尿失禁については、ないかすっても少量のるの が 7 名, 膀胱内飞尿が充满すると漏れてしまう溢流性尿失禁が 9 名, 陔や体動時 に漏れる腹压性尿失禁が 10 名、尿意のあるなしに関わらず、自然に排尿反射が起 てって止めるととがでをないるのが 6 名、ひとたび尿意を感じると短時間のらち 飞漏れてしまう切迫性尿失禁が9名である。核上型では自動排尿, 切迫性尿失禁 によるるのが多く、核・核下型では溢流性, 腹圧性尿失禁が多的。を尿失禁の 少ない7名中 6 名は会陰部飞痛覚が保たれている(表3，4）。尿失禁防止のため の患者の工夫は、排尿回数を增やすが 10 名, 集尿器。おむつ類の使用が 15 名，水 分をひかえるが 1 名で、2名で抗コリン剤を内服している。最後に尿路感染であ るが年に数回以上、腎孟腎炎に上ると思われる熱発のあるすのが6名で4名が核 上型。2 名が核・核下型であり、6名とる会陰部の痛覚はない。

〔考察〕春損患者にとって、腎不全に宿いるてとなく、尿失禁の消失すること が健康上おょび生活上、最良の管理方法であろら。今回検討した30名中、経過中 
に腎機能低下ををたしたすのが 2 名て、1名は核上型をクモ膜下フェノールブロ ックにて核下型とし間歇的自己導尿とした。1名はやむをえず留置カテーテルと した。また 2 名飞膀胱内圧の上昇がみられ、1名は括約筋切開術にて減压飞成功 し、残り 1 名るフェノールブロツクか括約筋切開を予定している。以上 4 名はす べて核上型で完全損傷例である。一般に脊損患者において腎機能の低下が起てる のは、膀胱排尿筋と括約筋が協調しないため膀胱内圧が上昇し、尿管上り膀胱内 に尿が輸送でをず、また V U R の出現により上部尿路の圧が高まるからであるう。

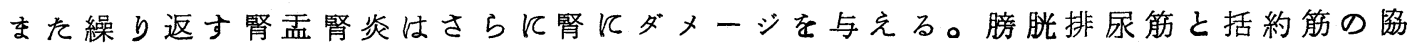
調は上位排尿中枢が司ると考えられており、完全損傷ではててからの連絡路が断 たれてしま5。会陰部の痛覚が残っているすのはての連絡路が保たれているとの 考えがあり、この点に着目してアンケートを分析してみると、会陰部の痛覚があ るものは、自然な尿意をすつるのが多く、尿失禁す比較的少なく、腎孟腎炎す少 ない。乙れは膀胼内王が上昇せず、残尿も少ないためであろう。逆に会陰部の痛 覚がないすのは、尿意す自然な るのはなく、失禁が多く、熱発 の機会子多的ししがってての タイブは要注意といえよう。核

・核下型であれば膀胱内压が上 䄯してをたり、失禁が多くなれ ば間歇的自己導尿飞変更が可能 であるが、核上型であれば、困 難る多い。しかしヶースに応じ て、膀胱減圧の種々の手段を考 慮しなければならない。

〔結論〕

1.会陰部の痛覚が残っている すのは核上型も核・核下型も 比較的コントロールが良好で ある。

2 ・会陰部の痛覚のないるのは 種々のトラブルを起としやす く、注意梁い観察が必要であ る。

3.核上型の膀胱減圧方法には 考慮の余地がある。

表 1 排尿様式

\begin{tabular}{|l|c|c|}
\hline & 核 上型 & 核・核下型 \\
\hline 自 然 排 尿 & 1 & 2 \\
Crede法 & 1 & 12 \\
ひをがね排尿 & 7 & 0 \\
間歇的自己導尿 & 2 & 3 \\
カテーテル留置 & 1 & 0 \\
失禁に上るすの & 1 & 0 \\
\hline
\end{tabular}

表 2 尿 意

\begin{tabular}{|c|c|c|}
\hline & 会陰部痛覚 $(+)$ & 会陰部痛覚 $(-)$ \\
\hline 自然の尿意 $(+)$ & $13 / 15$ & $1 / 15$ \\
\hline
\end{tabular}

表了失禁の種 類

\begin{tabular}{|c|c|c|c|c|}
\hline & 核 & 上 & 型 & 核・核下型 \\
\hline 無しまたは少量 & & 2 & & 5 \\
\hline 溢流性尿失禁 & & 2 & & 7 \\
\hline 腹圧性尿失禁 & & 4 & & 6 \\
\hline 排尿反射による & & 4 & & 2 \\
\hline 切迫性尿失禁 & & 8 & & 1 \\
\hline
\end{tabular}

表 4

\begin{tabular}{|l|c|c|}
\hline & 会陰 部痛覚 $(+)$ & 会陰部痛覚 $(-)$ \\
\hline 失禁 が 少量 & $6 / 15$ & $1 / 15$ \\
\hline
\end{tabular}




\section{8 経皮的腎・尿管結石砕石術の経験}

藤井元広, 角井徹, 森山浩之

(広島県厚生連広島総合病院)

はじめに

上部尿路結石に対する新しい治療法として，内視 鏡的手術が急速譜及してきたため，従来の“いわ ゆる外科的手術”は施行されなくなった[表 1 〕 内視鏡的手術には, 経皮的腎・尿管結石砕石法〔P N L) と経尿道的尿管結石砕石法 ( T U L) の 2 種 類あるが，今回は当院での P N L の手技，臨床成績 を報告する。

表 1 尿路結石患者の手術統計 [広島総合病院]

\begin{tabular}{|c|c|c|c|c|c|c|c|}
\hline 手 術 & 昭56 & 昭57 & 昭58 & 昭59 & 昭60 & 昭61 & 昭 62.4 \\
\hline 腎切石術 & 0 & 1 & 2 & 3 & 1 & 0 & 0 \\
\hline 腎盂切石術 & 4 & 0 & 3 & 6 & 3 & 0 & 0 \\
\hline 尿管切石術 & 9 & 7 & 11 & 4 & 13 & 5 & 0 \\
\hline 膀胱切石術 & 0 & 2 & 1 & 1 & 0 & 2 & 0 \\
\hline 膀胱砕石術 & 0 & 8 & 8 & 9 & 2 & 11 & 0 \\
\hline $\begin{array}{lll}P & N & L\end{array}$ & & & & & 1 & 38 & 22 \\
\hline $\mathrm{T} \quad \mathrm{U} \quad \mathrm{L}$ & & & & & 1 & 21 & 15 \\
\hline 計 & 13 & 18 & 25 & 23 & 21 & 77 & 37 \\
\hline 手 術 総数 & 166 & 177 & 213 & 187 & 202 & 249 & 104 \\
\hline$\%$ & 7.8 & 4.5 & 7.5 & 6.9 & 9.4 & 30.9 & 34.6 \\
\hline
\end{tabular}

対象, 手技

上部尿路結石を，Rocco の分類に準じて分類した[図 1 ]。

対象は，昭和 60 年 11 月より昭和 62 年 4 月ま でに当院泌尿器科を受診した上部尿路結石 症58例〔腎結石33例，尿管結石28例〕であ る!表 2 〕。性別は, 男41例，女17例，結石 の患側は, 右 22 例, 左33例, 両側 3 例, 結 石の数では, 単一34例, 多発22例, サンゴ 状 5 例である。Rocco の分類では, $\mathrm{U}_{1}$ が 28例とむっとも多く，ついで $\mathrm{C}_{3} 15$ 例， $\mathrm{C}_{2}$ 12例である。P N Lの手技は, 図 2 のごと くである。

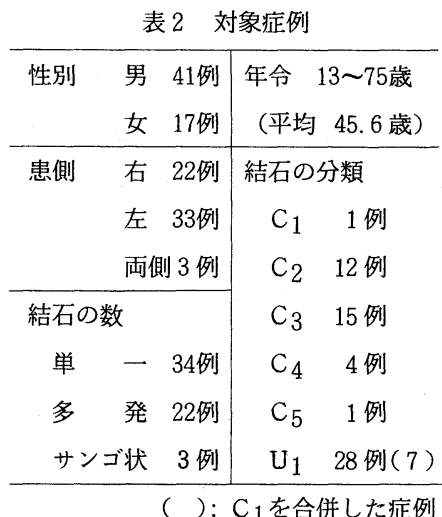

（）：C 1 を合併した症例

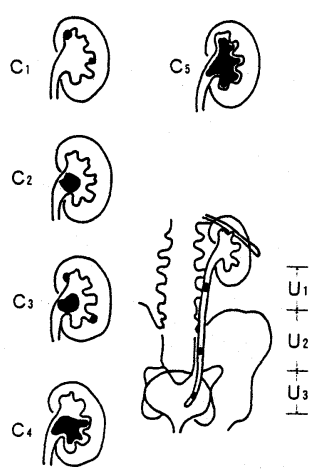

図1 結石の分類 成績

P N L の砕石方法, 手術回数, 手術時間を表 3 亿一括し た。結石の砕石は，主に超音波破砕でおてなった。手術回 数は, 平均 1.22 回であるが, $\mathrm{C}_{3}, \mathrm{C}_{4}, \mathrm{C}_{5}$ の多発結石 やサンゴ状結石で手術回数が多かった。手術時間は，2期 的手術および軟性鏡などに要した時間のトータルであり， $\mathrm{C}_{3}, \mathrm{U}_{1}$, サンゴ状にて長くなっているが, 平均 167 分で あった。腎瘻カテーテル留置期間は, 最短 2 日間, 最長 37 日間で，平均 9.8 日であった〔表 4]。

1. 尿管バルーン留置

2. 超音波ガイド下経皮的腎瘦造設 - US 対応針 $[18 \mathrm{G}]$

・筋膜ダイレーター [6 Fr $\rightarrow 14 \mathrm{Fr}]$

・金属ダイレーター [9 Fr $\rightarrow 26 \mathrm{Fr}]$

・一期的〔当日〕または二期的〔 $4 \sim 5$ 日後〕

3. 経皮的結石砕石術 ( $\mathrm{X}-\mathrm{P}$ 透視下)

4. 順行性腎孟造影

5. 腎瘻カテーテル抜去

P N L の臨床成績は，結石を完全に摘出した症例を完全 摘出例とし，小さな残石をみとめるも結石による尿路通過障害をとりのぞいたむのを臨床的成功例として 検討した〔表 5 〕。完全摘出率は，86.9\%であり，臨床的成功率は， $98.3 \%$ あった。不成功例の 1 例は 開腹術に変更した。P N L の術中, 術後の合併症は, 穿孔 9 例, 発熱 9 例, 出血 5 例などであるが, いず 
れあ保存的治療で改善した〔表 6$] 。$

P N L の術前, 術後の血液検査 の変動では, 赤血球数, へモグ

ロビンの有意の低下を認めた闵

3]。結石の成分は, シュウ酸打

よびリン酸カルシュウムを含む

結石が95\%をしめた[表 7 〕

P N L 術後の入院期間は, 14

21日間がほとんどで，平均 18.7

日であった[表 8 〕

表 3 砕石方法, 手術回数, 手術時間

\begin{tabular}{lccccccc}
\hline 結石の分類 & $\mathrm{C}_{1}$ & $\mathrm{C}_{2}$ & $\mathrm{C}_{3}$ & $\mathrm{C}_{4}$ & $\mathrm{C}_{5}$ & $\mathrm{U}_{1}$ & 計 \\
\hline 症 例 数 & 1 & 12 & 15 & 4 & 1 & 28 & 61 \\
\hline 二期的手術例 & 1 & 2 & 8 & 1 & 0 & 5 & 17 \\
\hline $\begin{array}{l}\text { 砕 石 方法 } \\
\text { 超 音 波 }\end{array}$ & 1 & 9 & 14 & 4 & 1 & 19 & 48 \\
電気水圧衝撃波 & & 1 & & & & 2 & 3 \\
鉗 子 子 & & 3 & 1 & & & 9 & 13 \\
\hline 手術回数〔平均〕 & 2 & 1 & 1.26 & 1.75 & 2 & 1.22 & 1.22 \\
\hline 手術時間〔平均, 分〕 & 215 & 106.2 & 191.8 & 306.3 & 195.0 & 151.9 & 167.0 \\
\hline
\end{tabular}

まとめ

（1）上部尿路結石58例に対し

て，PN Lを61回施行した。

（2）臨床成績は, 結石の完全

摘出率 $86.9 \%$ あ゙あり, 不

成功例は 1 例のみであった。

(3) 合併症は, 穿孔, 出血,

表 4 腎瘦カテーテル留置期間

発熱，水胸などがあったが，いずれも保存的治療でことなきを得た。

（4）上部尿路結石に対する新しい治療法として，P N L は今後ますます普及すると考えられた。

表 5 臨 床 成 績

\begin{tabular}{|c|c|c|c|c|c|c|c|c|}
\hline \multicolumn{2}{|c|}{ 結石の分類 } & $\mathrm{C}_{1}$ & $\mathrm{C}_{2}$ & $\mathrm{C}_{3}$ & $\mathrm{C}_{4}$ & $\mathrm{C}_{5}$ & $\mathrm{U}_{1}$ & 計 \\
\hline \multicolumn{2}{|c|}{ 症 例 数 } & 1 & 12 & 15 & 4 & 1 & 28 & 61 \\
\hline \multirow{3}{*}{ 成績 } & 完全摘出例 & 1 & 12 & 11 & 3 & 1 & 25 & 53 \\
\hline & 残 石 例 & & 0 & 4 & 1 & 0 & 2 & 7 \\
\hline & 不成 功例 & & & & & & 1 & 1 \\
\hline \multicolumn{2}{|c|}{ 完全摘出率〔\%〕 } & 100 & 100 & 73.3 & 75.0 & 100 & 89.2 & 86.9 \\
\hline \multicolumn{2}{|c|}{ 臨床的成功率： } & 98. & $\lceil 60$ & 1 例了 & & & & \\
\hline
\end{tabular}

\begin{tabular}{|c|c|c|c|c|c|c|c|c|}
\hline 合併症 & $\mathrm{C}_{1}$ & $\mathrm{C}_{2}$ & $\mathrm{C}_{3}$ & $\mathrm{C}_{4}$ & $\mathrm{C}_{5}$ & $\mathrm{U}_{1}$ & 計 & 〔発生率\%] \\
\hline 孔 & & 3 & 2 & & & 4 & 9 & {$[14.7 \%]$} \\
\hline 腎瘦造設時 & & 2 & 1 & & & 1 & 4 & [ $6.5 \%]$ \\
\hline 血 & & 1 & 2 & & 1 & 1 & 5 & {$[8.2 \%]$} \\
\hline 胸 & & & & 1 & & & 1 & ( $1.6 \%$ ) \\
\hline 呼 吸困難 & & & & & & 1 & 1 & [ $1.6 \%$ ] \\
\hline み & & & 1 & & & 3 & 4 & {$[6.5 \%]$} \\
\hline 熱 & & 2 & 2 & & 1 & 4 & 9 & (14.7\%) \\
\hline
\end{tabular}

\begin{tabular}{cc} 
表 8 & 入院期間 [ PNL 術後] \\
\hline 期間〔日] & 症例数 \\
\hline$\sim 14$ & 19 \\
$15 \sim 21$ & 29 \\
$22 \sim$ & 10 \\
\hline 平均 & 18.7 日 \\
\hline
\end{tabular}

表 7 結石成分

\begin{tabular}{lr}
\hline シュウ酸カルシュウム & 16 例 \\
リン酸カルシュウム & 3 例 \\
シュウ酸・リン酸カルシュウム & 36 例 \\
リン酸Mg アンモニウム & 1 例 \\
尿 酸 & 1 例 \\
不 明 & 1 例 \\
\hline
\end{tabular}

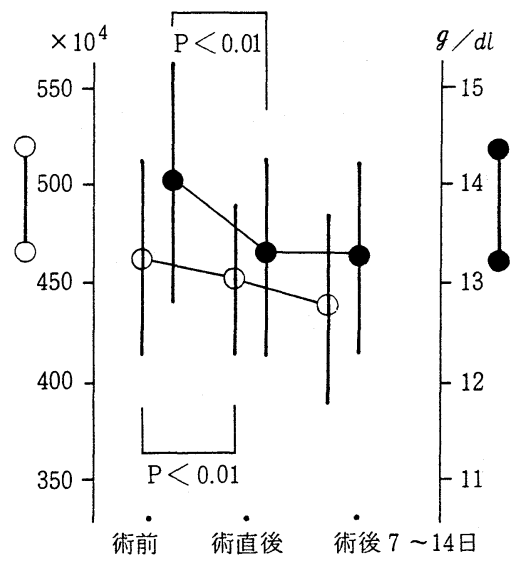

図 3 赤血球数 \& ヘモグロビン

[Mean士SD? 
(秋田県厚生連平鹿総合病院皮膚科)

はじめに：性交為感染症は現在日本でも注目を集めるAIDSをむ含め多彩な疾患があげられ るが, 当科でも陰部ヘルペス, 尖圭コンジロームなどのウイルス疾患, 疥痽, 毛風などの寄生 性疾患, 真菌性疾患む少なからず経験する所である。横手市を中心とした秋田県南地方は農村 地区ではあるが最近我々は相ついで顕症梅毒を経験し, 梅毒む全国的には減少傾向から増加の 方へ転じているようであり往年の疾患ではないととを念頭に拈きたいと思う。

以下疾患別に考えてゆきたい。

1)梅毒：当科で経験した顕症梅毒は(1)25才男（'85），(2)42才男（'86)であり，注目すべき点は 両者とも明らかな皮疹等を催しながら, 血液センターより献血の際に梅毒血清反応が陽性であ る旨通知を受け初めて来院した事である。乙れは以下の問題点を含んでいる。第 1 亿問診等よ り，不特定の異性との性交涉後に梅毒を心配し， かつ病院での検査診察への心理的抵抗感から 安易に検査してもらえる献血に走っている点, 第 2 に血清反応が陽性に出る前の患者の血液が 使用に供される懸念がある点である。また症例 (2)は感染経路が不明だが，(1)はいわゆるソープ ランドでの感染で, 遊興施設の予防対策の不備が問題と思われた。

2)尖圭コンジローム（表 1，2）：尖圭コンジローム全てがSTDではないが，成人の場合は 可能性が高い。ほとんぞが液体窒素凍結療法 1 〜数回で治癒するが, 大型で角化傾向が強く, 一部が潰瘍化している場合（Buschke－Loewen - stein tumor）には有棘細胞癌との鑑別屯 必要でかつ難治である。当院での症例む減って扔らず，また男子に多い傾向がある。

3)外陰部ヘルペス（表 3，4）：当院であ圧倒的に男にみられ，年令も20代が多い。全国的に はふえる傾向があるという。接触皮膚炎, 梅毒疹, カンジダ症等を鑑別しなければいけないが 診断は難しくはないと思われるが，治療に関し，再燃をくり返すケースは問題となる。

4)毛虫症（表 5，6）：乙れは罹患者は全てSTDとしてよいと思われる。日本では海外渡航 がさかんになり増加していると思われるが当院でも増減はあるものの減る傾向はない。フェノ トリンパウダーで約 1 週間で剃毛することなく完治している。

5)疥痽（表 7,8 ）：乙れはSTDでああると同時に, 寝具を介して感染するため, 家族内, 集団生活者などで爆発的に流行することがあり，当院でも養護施設児の大量発生を経験してい る。0.5\%マラソンローション,オイラックス軟膏, イオゥ浴等で治療している。 
表 1. 尖圭コンジローム年別性別来院数

\begin{tabular}{|c|c|c|c|c|c|c|}
\hline & '83 & '84 & '85 & '86 & $\begin{array}{l}\text { 87 } \\
\text { 7月まで }\end{array}$ & 計 \\
\hline 男 & 2 & 2 & 3 & 3 & 2 & 12 \\
\hline 女 & 0 & 0 & 1 & 1 & 0 & 2 \\
\hline 計 & 2 & 2 & 4 & 4 & 2 & 14 \\
\hline
\end{tabular}

表 3. 外陰部ヘルペス年別来院数（男のみ）

\begin{tabular}{|c|c|c|c|c|c|c|}
\hline 年別 & '83 & '84 & '85 & '86 & $\begin{array}{l}87 \\
7 \text { 月まで }\end{array}$ & 計 \\
\hline 男 & 2 & 1 & 2 & 1 & 0 & 6 \\
\hline
\end{tabular}

表 5. 毛闽症年別性別来院数

\begin{tabular}{|c|c|c|c|c|c|c|}
\hline & '83 & '84 & '85 & '86 & $\begin{array}{l}\text { 87 } \\
7 \text { 月まで }\end{array}$ & 計 \\
\hline 男 & 4 & 4 & 1 & 0 & 2 & 11 \\
\hline 女 & 1 & 0 & 0 & 0 & 1 & 2 \\
\hline 計 & 5 & 4 & 1 & 0 & 3 & 13 \\
\hline
\end{tabular}

表 7. 疥癖年令別性別来院数

\begin{tabular}{|c|c|c|c|c|c|c|}
\hline & '83 & '84 & '85 & '86 & $\begin{array}{l}\text { '87 } \\
\text { 7月まで }\end{array}$ & 計 \\
\hline 男 & 2 & 0 & 1 & 2 & 0 & 5 \\
\hline 女 & 4 & 0 & 1 & 0 & 0 & 5 \\
\hline 計 & 6 & 0 & 2 & 2 & 0 & 10 \\
\hline
\end{tabular}

\begin{tabular}{|c|c|c|c|c|c|c|}
\hline 年令 & 10 代 & 20 代 & 30 代 & 40 代 & 50 代 $<$ & 計 \\
\hline 男 & 1 & 4 & 0 & 0 & 0 & 5 \\
\hline 女 & 0 & 0 & 2 & 3 & 0 & 5 \\
\hline 計 & 1 & 4 & 2 & 3 & 0 & 10 \\
\hline
\end{tabular}

（以上統計は全てSTD と考えられた数である）

表 2. 尖圭コンジローム年令別性別来院数

\begin{tabular}{|c|c|c|c|c|c|}
\hline 年令 & 10 代 & 20 代 & 30 代 & 40 代 $<$ & 計 \\
\hline 男 & 0 & 5 & 5 & 2 & 12 \\
\hline 女 & 0 & 2 & 0 & 0 & 2 \\
\hline 計 & 0 & 7 & 5 & 2 & 14 \\
\hline
\end{tabular}

表 4. 外陰部ヘルペス年代別来院数（男のみ）

\begin{tabular}{|c|c|c|c|c|c|}
\hline 年令 & 10 代 & 20 代 & 30 代 & 40 代 $<$ & 計 \\
\hline 男 & 0 & 4 & 1 & 1 & 6 \\
\hline
\end{tabular}

表 6. 毛闽症年令別性別来院数

\begin{tabular}{|c|c|c|c|c|c|c|}
\hline & 10 代 & 20 代 & 30 代 & 40 代 & 50 代 $<$ & 計 \\
\hline 男 & 0 & 2 & 2 & 5 & 2 & 11 \\
\hline 女 & 0 & 1 & 0 & 0 & 1 & 2 \\
\hline 計 & 0 & 3 & 2 & 5 & 3 & 13 \\
\hline
\end{tabular}

表 8. 疥癖年令別性別来院数 
610 ストーマケアの患者指導（回腸導管造設術を受けた 1 症例） ○佐久間みつ子, 羽持律子

( 総合病院土浦協同病院混合病棟)

1・はじめに

当病院に打いて, 膀脱全摘, 回腸導管造設術が年々増加の傾向にある。 ストーマを造設する患者の不安は, 精神的; 身体的にあ, 計り知れないむ のがある。膀胱全摘術後のストーマの生活管理は, 看護婦に委权られる部 分が大きい。早期にストーマを受容し，正しく自己管理ができるように， ストーマ造設患者に対する指導内容を検討し，指導援助を行なったので， 報告する。

\section{2. 症例紹介}

患者：61才男性病名：膀胱腫瘍

入院期間：昭和 62 年 3 月 10 日 62 年 6 月 9 日

現病歴及び経過

昭和 61 年 12 月頃より排尿時痛あり時折血尿出現す。近医受診, 症状軽減 しないため, 昭和 62 年 2 月 27 日当院泌尿器科受診, 手術目的にて入院す。 昭和 62 年 3 月 16 日 T U R - B i ops y 施行, 結果, 悪性度高いため, 昭和 62 年 5 月 8 日膀胱全摘, 回腸導管造設術施行, 術後合併症なく順調に経過す。 また,ストーマの自己管理指導し, 装具装着を習得し退院となる。

\section{3，看護の展開}

1 ) 問題点: ストーマの知識不足からくる自己管理困難

2 ）看護目標：ストーマを受容し，自己管理ができるように，指導援 助する。

指導内容

1 ) ストーマ（回腸導管開口部）とは，どんな あのであるか

$2)$ ストーマの目的

3) パウチ, 装具類の紹介と使用方法図 1

4 ）ストーマの管理：装具の貼り替え方, 固 定の仕方

5) 日常生活について：食事, 入浴, 服装, 仕事

6) 経済面: 福祉制度の活用障害年金

7 ）社会面：互療会の紹介

装具装着手順

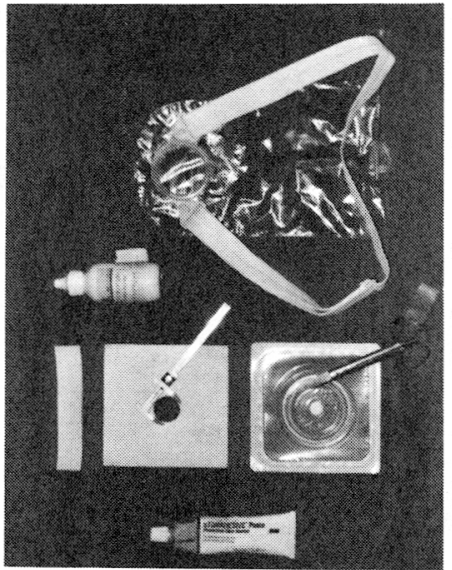

図 1

1) 装具の切り方ストーマの型紙で, 装具の裏側に印を付け八サミミ゙ 切る。内径 $1 \mathrm{~cm}$ は残す。 
2 )装具を除去する：アイスノンを当て, その後ゆっくり上から下にはが す。ストーマ周囲を微温湯タオルや石鹼で清拭する。

了) 石簽水を十分除去した後, 皮膚を自然乾燥させる。

4 )その間尿がたえず流れるので，ガイドペーパーを使用する。

5 ) 深呼吸をして, 腹部を膨らませたときて, 下忌ら上飞貼り付ける。

6 ) 装具の方向は, 術直後は横向き, 歩行可能後は縦向きに貼る。

7 ) 皮膚のくぼみ，ストーマと装具のすき生はは, パウダー又はペース 卜を使用する。

\section{4. 看護の実際}

術直後, ワンピース型ストーマ, ユーリンバックが装着される。術後 4 日目に, 尿漏れ見られ第1回目の装具交換を実施した。術後 8 日目ょり尿 漏れ頻回となり, ストーマ周囲に疼痒感, 発赤が出現した。スト一マ周囲 に, ステロイド軟膏塗布を施行したが軽減しなかった。そてで, 制酸, 胃 粘膜保護剤であるマーロックスを塗布して椂子観察した。結果として, ス トーマ周囲の炎症は消失した。術後10日目より歩行可亡なった。創部のく ぱみあ尿漏れの原因と考えられるため, 退院後装着装具目的にて, ッ一ピ ース型,バリケアーフランジ,ユリナバック $45 \mathrm{~mm}$ に变更し, 装具装着手順 に基いて, 第 1 回目の指導を行なった。問題点を把握し, 対処するととに よって, 患者とのコミュニケーションが取りやすくなった。しかし尿漏れに 対する不安が強く, 装具装着も妻に依存しているようであった。第2 2 回目の 指導は，尿漏がなくてあ，フランジの解けぐあいを見て，患者の意識を高 められるよう積極的に行なった。第 3 回目は, 退院指導を含めて, 患者之 妻に行なった。次第に患者の受け入れむ良くなり，患者自身装着を行ない 工夫する姿勢が見られた。その際, ス卜ーマの大きさが变化することを伝 え型紙の取り方を指導した。な技皮虑炎予防と装具固定のため, 腹带千工 ーブとバンドを使用した。図2,また週に1回は装具をはずしての入浴之 5 分間の日光浴を勧め, 皮膚の観察をするように指導し, 装具の購入方法 と, 互療会について説明した。

\section{5. 考 察}

今回，ストーマケアに対するイメージが漠然とし ていた患者に, 用具の名称や特徵, 使用方法, パン フレットの内容と実際が結びつくように指導した。 さらに交換時は，看護婦が励ましと共に赛践したこ とにより, 理解が深まりとれらを習得させることが できた。ストーマケアは精神的な援助や技術習得の ため指導援助が最む必要之考える。また, ス卜ーマ ケアのフォローが, 現状では確実になされていない。

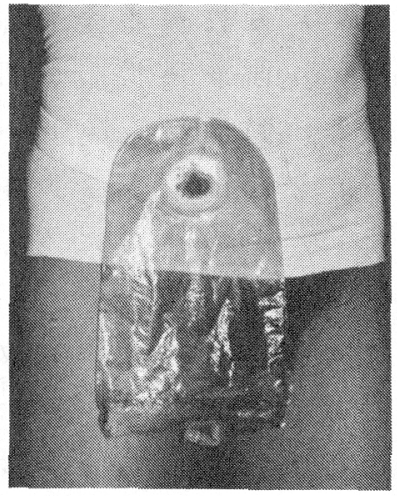

図 2 今後外来の協力屯得て, 入院患者の情報を看護サマリーとともに提供し, 外来での継続看護へと結びっけたい。 


\section{1 慢性腎不全患者の透折導入期指導ーマニュアルを用いて}

。阴脇常子, 松崎晴子, 石山貞子, 岡野秀子 竹村志津子, 磯山洋子, 伊藤和子 土浦協同病院東五階

はじめに

当院東 5 階内科病棟では慢性腎不全患者の入院が多く，そのほとんどが 血液透析療法導入期，あるいは導入後の合併症によるあのである。昭和 61 年度には新たに30例が血液透析療法に導入された。長い慢性腎機能障害の 闘病生活の未に, いょいょ血液透析導入を迎えた患者の心理状態は筆舌に 尽くし難いものと考えられ, 理解の不足から透析イコール死亡とらえて導 入を拒否し, 尿毒症の症状が悪化し,なかば昏睡状態の中でシャント造設 術を施行せざるを得ない症例にも多数遭遇している。こうした状況の中で 私達看護の果たすべき役割は，医師の患者への指導方針に基づいて疾患に ついて正しい知識をむたせると共に, 精神的な準備を援助し，さらに透析 導入後のシャント，その他日常の自己管理と指導等を徹底して行い, 外来 透析への橋渡しとなるととと考えられる。そのために私達は，透析導入期 患者に対して一貫した指導を行うべく, 病棟独自の看護マニュアルを作成 し看護に当っているので,その結果を分析し検討した結果を報告する。

〔看護マニュアルの構成並びに実施方法〕

第 1 段階: 「腎不全パンフレット」（慢性腎不全の正しい知識一丸茂文 昭著南江堂）を用いた疾患の理解。

1) 腎臓は体のどこにあるのでしょう。

2 ）腎藏の働き。

3 ) 腎不全とは。

4 ）尿毒症とその症状。

5 ）慢性腎不全と尿毒症の治療。

6 ）血液透析の原理。

7 ) 動静脈 シャントについて。

第 2 段階: シャント造設術, 術前, 術後の個別指導。

1 ）造設前日にシャントの必要性と術前管理について, (痛み, 抜系, 指の運動方法)

2 ) 造設後に半永久的な保存方法（利き手と反対側飞造る。重い物を持 たない等)

第 3 段階: 腎センタ一見学。（必要性の理解を深める為実際に目に訴え る。)

以上の 3 段階に従って, 昭和 61 年度, 年間 30 例に患者指導を行い, その間 の患者側の反応及び看護面の問題点を症例毎に明らかにした。 


\section{〔結 果〕}

患者側の反応としては以下のような事項が多かった。

1 ) 血液透析の時間と回数。

2 ）経済的によ゙うなるか。治療費, 仕事の継続の可能性など。

3 ）透析導入後の寿命はどのくらいか。

4 ）シャントに支障を来たした場合の不安。

看護側から提起された問題点の主なあのは以下の通りであった。

1) 統一した看護マニュアルに基づいた指導により, 透析導入を拒否す る例は明らかに減少した。

2 ）一度は理解出来たと判断された例であ, 再度の個別指導の際に意外 な点が理解されていない場合が多かった。

3 ）実際に血液透析療法に入ってからの患者の日常生活の変化などの資 料が欲しい。

\section{[考察]}

慢性腎不全で血液透析導入期に入った患者の精神状態は極めて不安定に なっていることが想像され, 又, その程度む患者個々によって多様である。 従って看護面からの対応す困難な場面に遭遇することが多い。今回私達が 試みた透析導入期の患者に対する統一した看護マニュアルは患者指導に扔 ける看護婦間の差を少くし，しかあ指導の質の向上を目指したあのであっ たが, 透析導入に際して患者が拒否する場合は明らかに減少した点で有効 性が確認された。一方, 患者側からの反応として, 経済的な問題や仕事を 継続していけるかなど, 日常生活を営むための極めて具体的事項に対する 不安が最む多かったがての点に関しては腎センタ一との接触を密にして, 当院で現在血液透析を受けている156名の患者の生活状況調查などを行い， その成績を参考にして患者指導を行えば更に充実した成果が期待され, 今 後の課題とした。また, 指導に対する患者側の理解度が様々で㐫る点は避 けられないが, 理解を得ることが困難な例には, 家族へのアプロ一チを密 にすることや指導の繰り返しなど多方面からの工夫が必要であるてとを痛 感した。

\section{[まとめ]}

土浦協同病院東 5 階内科病棟で血液透析導入期を迎えた慢性腎不全患者 に, 私達が独自に作成した看護マニュアルを用いて患者指導を行なった。 導入時の患者の理解不足による種々のトラブルは明らかに減少し有効であ ったが, 患者側の要求は日常の具体的な事項にまで及ぶことが明らかとな り,乙の点に関して, 更に資料を得て, マニュアルを補充していくてとが 今後の課題である。 
$\bigcirc$ 飯岡栄子, 柏富代, 横山とし子, 宮崎佳子, 広木茂美 ( 水戸協同病院腎センタ一)

\section{〔はじめに〕}

近年, 透析療法の進歩にともない長期生存む可能となってきた。当施設であ, 安定期の透析患者は, 増加の傾向をたどり全体の $47 \%$ を占めている。安定期に入 るにつれ，患者自身も透析療法に対する受容や自己管理ができてくるが，ての時 期での看護の果たす役割は軽視できない。今回, 安定期透析患者に対し患者サイ ドからみた看護のあり方，透析療法の受容の度合などについて意識調查を行った。

\section{[対象および方法]}

透析を受けている患者 10 名を対象とし， 調查対象概要は表 1 のでとくである。方 法はアンケート用紙を対象者に配布し, 家族と共に記載するようにした。

\section{〔調查結果および考察〕}

1)患者と看護婦のかかわり合い（表 2 )

患者からみて, 看護婦は話し安く人数 あ足りていると答えているが, 将来につ いて話した事はなく，透析中不安な事が あると答えた人が多いのに驚いた。マン ネリ化になりがちな看護の中で, 患者の 態度ひとつで看護を省みた事が幾たびか あり，自己満足的になりがちな看護につ いて反省させられた。これからの看護の中で, 患者をどれだけ受容できるかは疑 問ではあるが, 患者との信頼関係を築づくためにもべットサイドでの看護を心が けたい。

2) 患者と医師とのかかわり合い（表 3 ）

当施設の場合, 医師が泌尿器科と兼務している為, 患者と接する時間が限られ ている。医師に対して患者は複数である為，患者ひとりひとりの関り合いが持て ず, 会話をあってほしいと答えた人が多い。しかし, 患者は医師に対する信頼度 は強く，常に理解していてほしいと望んでいる。医師と患者の信頼関係を高める 為, 看護婦の役割は重要である。

3)透析方法をどのように受けているか（表 4 )

てれからあ透析を頑張って受けて行きたい, いっも透析のてとを考えていると 答えた人が多い。透析を生活の一部としてとらえ, 現状維持を望んでいると思わ れる。

4)改めて透析療法について指導を受けたいが, 自己管理をするうえで大切な食 事療法, 薬又は合併症についての指導を希望している。

5 )その他（表 5 ） 
家族状況は表 1 のでとくである。生計の中心は, 配偶者及び子供である。年金 受給者は 9 名で障害年金が殆どである。他 1 名は年金を受けておらず，妻が働い て生計をたてている為, 透析にかかる費用が負担であると答えている。今後仕事 をしたいと答えた 3 名は，核家族であり，40才という年令からあ生計をたてる為 であると思われる。非透析日の生活状況は, 散歩をしたり，家事手伝をしている 人が多い。また, 趣味をあっている人は多いが, 健康な時からの趣味で, 透析療 法を受けてからは趣味が生かされていない。

\section{2) 患者と看護㜴とのかかわり合い（表 2 )}

\begin{tabular}{|l|r|}
\hline a) 文いつをかわしている & 10 名 \\
b) 健康状態を話すととができる & 9 名 \\
c) 看護婦と話しやすい & 9 名 \\
d) 将来について話しをした事がある & 1 名 \\
e) 症状について訴えやすい & 10 名 \\
f)看護婦がそばについていてほしい & 2 名 \\
g) 透析中不安な事がある & 2 名 \\
h) 看護婦の人数はたいてい & 6 名 \\
\hline
\end{tabular}

\section{3) 患者と医師とのかかわり合い（表 3 )}

\begin{tabular}{|l|r|}
\hline a) 文さつをかわしている & 9 名 \\
b) 症状について話すことができる & 8 名 \\
c) 医師の印象について & \\
$\quad$ 話しやすい & 8 名 \\
やさしい & 9 名 \\
$\quad$ 患者に対して思いやりがある & 10 名 \\
d) 患者と会話をむってほしい & 7 名 \\
e) 身体の調子について聞いてほしい & 5 名 \\
f) 医師は患者の身体について把握している & 7 名 \\
\hline
\end{tabular}

\section{4）透析療法をどのように受けいれているか（表 4 ）}

\begin{tabular}{|l|r|}
\hline a) がんばってやりたい & 8 名 \\
b)いつも透析の事を考えている & 6 名 \\
c) 現状維持ができればよい & 4 名 \\
d) しかたなく透析にきている & 2 名 \\
e) 腎移植を希望している & 2 名 \\
\end{tabular}

5) の 他 (表 5 )

\begin{tabular}{|l|l|}
\hline a) 仕事をしている & 2 名 \\
b) 散歩をしている & 8 名 \\
c) 老人クラブに入っている & 0 名 \\
d) ならい事をしている & 0 名 \\
e) 趣味をむっている & 6 名 \\
f) 年金を受給している & 9 名 \\
g) 透析にかかる費用が負担である & 1 名 \\
h) 今後仕事をしたい & 3 名
\end{tabular}

\section{〔まとめ)}

当施設に打いて, 看護婦 1 人 1 日当り透析患者は平均 3.4 人である。過酷な業 務の中でとかく流れ作業的になりやすく, 看護行為の中で, 心理面に対しての働 きかけが置き去りになりやすい。安定した透析を維持するさい, 私達は常に新し い知識を吸収し, 生活するてとに対して, 積極的になれるよう看護サイドから援 助して行きたい。患者は透析という柱に寄りかかりながら, 長期生存を願い生き て行かなければならない。我々医療スタッフは, 患者の立場に立って共に歩んで 行きたい。 
○城取久仁子, 岩渕淳子, 古渡裕子, 木戸雅子 石浜子ち子，須賀良子

（総合病院土浦協同病院腎センタ一）

はじめに

透析患者にとって, 社会復帰は最も重要な目標である。しかし, 近年高 令者及び合併症をあった患者の增加により，その目標あ困難となりつつあ る。現在当センターには, 155 名の外来透析患者がいるが, 社会復帰の実 態は充分には把握されていない。今回私達は, 比較的社会復帰がなされて いると思われる夜間透析患者59名を対象に, 就労状況のアンケート調查を 行い,まとめたので報告する。

1. 対象及び方法

週 3 回夜間透析患者を無作為に5 9 名選び, 無記名自己記入方式によるア ンヶート調查を行い,それらを集計した。

\section{2. 結果及び考察}

アンケート回収率は, 59 名中 42 名で $71 \%$ だった。

就労の有無については, 図-1飞示すょうに, 42 名中 40 名 $95 \%$ の患者が 社会復㷌している事がわかった。残り 5 \%の患者が復㷌していないが，そ

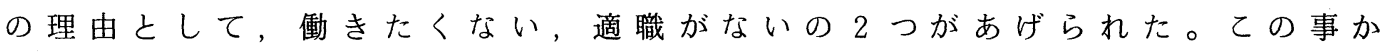
ら, 本人の意志亡自覚が社会復帰する大きな要因であると思われた。しか し, 問題は患者側だけでなく受け入れ側にああり，働きたくてあ㚪けない という状況から, 更に働きたくないという状況へと連なるのではないかと 思われる。

透析を受けてから復帰するまでの期間としては, 図一2に示すように, $0 \sim 3$ 力月と答えた者が 42 名中 25 名で $59.5 \% ， 4 \sim 7$ 月 8 名で $19 \% ， 8$ 〜 11 力月 3 名で $7 \% ， 1$ 年以上が 6 名で $15 \%$ だった。ての結果より, 半数 以上の者が 3 力月以内という早期飞社会復帰しているてとがわかった。

現在，就労している勤務先での協力度を知る為に問いかけた。協力的で あると答えた者は，42名中 39 名で殆んどの者が協力的であった。身体の調 子が悪い時，遠虑なく休めるかという問いに対しても，42名中 35 名 $87.5 \%$ で休めるという答えが得られた。このような結果から, 社会復帰のために は透析を受ける以前に就労していたてとにより受け入れ側の協力が得られ るよう思われる。

職種別としては, 図一 3 に示す通り, 会社員が 42 名中 19 名 $45 \%$, 自営業 が 8 名で $28.9 \%$ だった。この会社員で病前と同じ職場に戻るととが出来た と答えた者は配置転換があったととあ含めると 19 名中 18 名 $94.7 \%$ ，乙のて とから周囲が家人であったり，また復帰前の職場であったりする事が社会 
復㡒する良い条件と思われる。農業を職業としている者が 42 名中 11 名の 26 . $1 \%$ とう結果が出たが, 農業は季節に応じた忙しさがあるため, 病前と 同じ仕事量をてなしていれば $100 \%$ 社会復帰しているといえるが，あし農 作業に他人を頼むようなら部分復帰であり，自分が何あしなければ復帰し ているとはいえないので，どの位なされているか疑問である。

非透析日の労働時間を問いかけてみた。その結果は, 図一 4 に示す通り である。非透析日に，1 日平均 $7 \sim 9$ 時間と答えた者は，42名中 27 名 $64.0 \%$ $10 \sim 12$ 時間が 6 名で $14.2 \%$ という回答だった。又，透析日に定時刻まで就 労している患者は数える程度である事がわかり，まだ完全に社会復帰して いるとはいえない。このてとに対し，安定期の患者に於いて特別の理由が ない限り,なるべく定時刻まで就労してくるよう勧めている。

3.まとめ

(1)スムーズな社会復帰のためには, 透析前の職業を可能な限りやめない というととが重要である。

(2)復帰は, 本人の意志・自覚が大きな影響を与える。

(3) 周囲の協力が必要である。

(4)農業従事者, 会社員等の者たちについて, どの程度社会復㷌が果たさ れているかどうかは疑問である。

アンケートの結果により以上のてとがわかり，社会復帰している数は統 計的にとらえられたが, 密なあのはとらえていない。また，患者 1 人 1 人 様々な考え, 支障を持ち透析を受けている中で, まだまだ数多くの難問が 残されているが, てれらの問題を解決していく事が課題である。

図-1 就労の有無

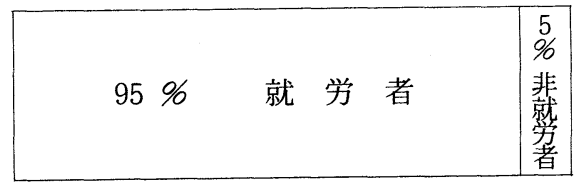

図一 2 復帰するまでの期間

\begin{tabular}{|c|r|r|r|}
\hline $0 \sim 3$ ケ月 & $4 \sim 7$ & $8 \sim 11$ & 1 年 \\
$59.5 \%$ & ケ月 & ケ月 & 以上 \\
& $19 \%$ & $7 \%$ & $15 \%$ \\
\hline
\end{tabular}

図 -3 職業 別

\begin{tabular}{|c|r|l|}
\hline 会 社 員 & 自 営 業 & 農 業 \\
$45 \%$ & $28.9 \%$ & $26.1 \%$ \\
\hline
\end{tabular}

図 - 4 労働 時間（非透析日）

\begin{tabular}{|cc|r|r|}
\hline $7 \sim 9$ 時 間 & $10 \sim 12$ & $1 \sim 6$ \\
$62 \%$ & $14.2 \%$ & $23.8 \%$ \\
\hline
\end{tabular}




\section{消化器疾患 III}

614

腸閉塞患者に対するガストログラフィン経口投与による 経時的腸撮影の意義

斉藤宏之鈴木彰

(秋田県厚生連湖東総合病院外科)

1. はじめに

イレウスに対して保存治療でよいか、あるいは手術を行うかの選択は必ずしす容 易ではない。演者らはイレウス症状を呈する患者にガストログラフィン（アミドトリ

ゾ酸）を経口投与し、経時的腸撮影を行なっているがイレウスの治療方針を決定する 上で有用であったので報告する。

2. 対象と方法

昭和 60 年 1 月から昭和 62 年 6 月までにイレウスと診断した患者 14 人を対象とした。 方法は経口的または経鼻胃管的にガストログラフィン $100 \mathrm{ml}$ を投与し投与後 1 時間毎、 原則として 3 時間まで経時的腸撮影を行なった。

症例を保存的治療を行なった群と手術的治療を行なった群に分け、ガストログラフ ィン投与 3 時間後の造影剤の到達部位を調べ比較検討した。

3. 結果

14 例中 9 例には保存的治療が、また 5 例には手術がそれぞれ行われた（表 1.2 )。 保存的治療のみで治瘉した 9 例についてガストログライン投与 3 時間後の造影剂の 到達部位をみると 8 例はいずれす横行結腸ないし直腸まで達した。残りの 1 例は上行 結腸に止まったが 5 時間後には直腸まで造影剤が達していた。ての群に属する症例で はすべてガストログラフィン服用後 4 日以内、大半は 3 日以内に経口摂取を開始でき た。他方、手術となった 5 例についてみると、ガストログラフィン投与 3 時間後の造 影剤の到達部位は判読不可の 1 例を除いていずれも上行結腸あるいは小腸に止まっ ており、横行結腸に達するものはなかった。てのうち2 例は結腸癌によるイレウス で本検査により癌の存在が疑われた。その他、瘉着性イレウス、特発性巨大結腸症の 各 1 例であった。以下、2. 3 の症例を供覧する。

\section{4. 考察}

イレウスの診断、治療方針の選択にあたっては臨床症状と腹部単純撮影所見が重要 であることは論をまたないが、てれだけで十分とは言えない。演者らは、治療方針の 決定の一助とする目的でイレウスに対してガストログラフィンによる経時的腸撮影を 試みた。その結果、ガストログライン服用 3 時間後の到達部位が有用な指標の 1 つと なると考えられた。すなわち、癒着性イレウスにあっては、ガストログラフィン服用 3 時間後造影剤が上行結腸ないし横行結腸より肚門側に達している場合は保存的治療 でよく、逆に小腸に止まっている場合は手術を前提に慎重に経過観察すべきである。 また大腸癌によるイレウスについては、造影剤の進行は、前記の保存的治療により 治癒した症例の場合より若干遅い。その場合、さらに時間を追って腸撮影を行うこと により病変が明らかになる場合ああり検查を進める必要がある。ガストログラインは 
高渗透圧作用により緩下剤としての効果も期待できるととも利点の 1 つと考えられる。

\section{表一1 保存的治療を行なった症例}

\begin{tabular}{|c|c|c|c|c|c|c|c|}
\hline No. & 年 齢 & 性 & 手 術 既 往 歴 & 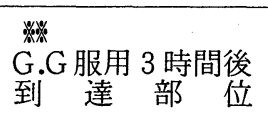 & $\begin{array}{l}\text { 服用 } \\
\text { 摂取開 }\end{array}$ & $\begin{array}{l}\text { 経ま口 } \\
\text { 紿まで }\end{array}$ & 転 帰 \\
\hline 1 & 54 & $\hat{\delta}$ & 外傷性腸間膜血腫 & 直 腸 & 3 & 日 & 治癒 \\
\hline 2 & 54 & $\hat{\delta}$ & 急性 虫垂 炎 & S 状結腸 & 3 & 日 & 治癒 \\
\hline 3 & 55 & $\hat{\delta}$ & $\mathrm{S}$ 状結 腸 癌 & 直腸 & 1 & 日 & 治癒 \\
\hline 4 & 18 & 우 & 急性虫垂 炎 & 横行結腸炎 & 3 & 日 & 治癒 \\
\hline 5 & 72 & $\hat{\delta}$ & 膀胱癌 & $\mathrm{S}$ 状結腸 & 4 & 日 & 治癒 \\
\hline 6 & 42 & 우 & $\mathrm{S}$ 状結腸軸捻転 & 下行結腸 & 2 & 日 & 治癒 \\
\hline 7 & 29 & 우 & 尿 管 膜 腫 瘍 & S 状結腸 & 1 & 日 & 治癒 \\
\hline 8 & 41 & $\hat{\delta}$ & 胆 石 症 & 上行結腸炎 & 2 & 日 & 治癒 \\
\hline 9 & 36 & 우 & 急 性 虫 垂 炎 & 下行結腸 & 2 & 日 & 治癒 \\
\hline
\end{tabular}

※ 5 時間で直腸まで達した。

欒 ガストログラフィン

表一2 手術的治療を行なった症例

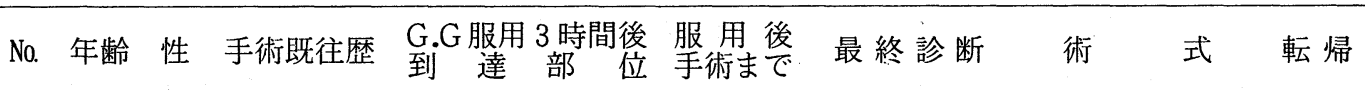

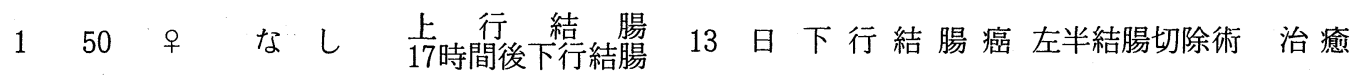

268 ㅇ 穿 孔 性 回腸以後動かす 4 時間 癒着性イレウス癒着剥離術治癒

382 昌 癌 上 行 結 腸 2 日 再登によ結腸の閉塞 人工肛門造設術 軽 快

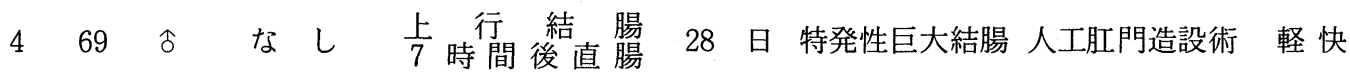

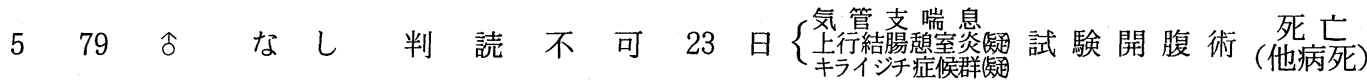




\title{
615 当院における高齢者イレウス手術症例の検討
}

\author{
$\bigcirc$ 河合雅彦近石登喜雄伊藤善朗 \\ 土屋十次星野睦 夫 \\ (岐阜揖斐総合病院外科)
}

当病院外科に扔いて昭和 57 年から昭和 61 年までの過去 5 年間に経験した イレウス手術症例は56 例である。乙のうち70才以上のいわゆる高齢者症例 26 例について統計的検討を加えた。〔表 1 〕は過去 5 年間のイレウス手術 症例。〔表2〕はその年齢別分布を示した。70才以上の高齢者イレウス手 術症例は全体の $46.4 \%$ あるる。〔表 3 〕は発生原因別分類を示す。単純性 イレウスが 37 例 (66.1\%) を占め、複雑性イレウスが残りの 19 例（33.9\%) を占めている。〔表 4 〕は閉塞部位を示す。小腸・下部大腸に多い傾向が 見られる。〔表 5 〕には、既往歴に開腹術を認め、てれがイレウス発生に 多少なりとあ考えられるいわゆる術後イレウス 27 例についてその既往手術 をまとめた。虫垂切除術、胃切除術が既往手術として多く見られる。〔表 6 了は70才以上の高齢者イレウス全手術症例を既往手術の有無により2つ に分け示した。又〔表 7 〕はその発生原因を良性・悪性に分け示した。 てれらによれば、既往手術のある14例のうち、術後イレウスは10例で全体 の $38.5 \%$ あるる。さらにその 10 例中 4 例は癌再発性のイレウスであった。 次に悪性腫瘍によるあのは、癌性イレウス、癌再発性イレウス、癌腫によ り腸重積を惹起した例を合わせ 15 例と全体の $57.1 \%$ を占めている。又手術 内容について見てみると人工肛門造設のみに終わっている症例が 8 例と、 $30.8 \%$ 亿及んで打り高齢者イレウスの一期的手術の難かしさを窥わせる。 さらに既往手術のない12 例のうち実に 4 分の 3 を占める 9 例が癌性イレウ スであった。

\section{(まとめ)}

過去 5 年間の高齢者イレウス手術症例 26 例中 15 例が癌腫によるイレウス であり、又既往手術のない12 例中 4 分の 3 を占める 9 例が癌閉塞性イレウ スであった。さらに既往手術のある 14 例中にあ 4 例の癌再発性のイレウス を見た。従って老人のイレウス特に既往手術のない老人のイレウスではま ず原因として癌を念頭に执き診断、治療を進めるととが必要と思われる。 
表 1 イレウス手術症例

\begin{tabular}{|r|r|r|r|}
\hline & 症例数 & 男 & 女 \\
\hline 昭和 57 年 & 7 & 4 & 3 \\
58 年 & 8 & 5 & 3 \\
59 年 & 12 & 8 & 4 \\
60 年 & 9 & 4 & 5 \\
61 年 & 20 & 12 & 8 \\
\hline 計 & 56 & 33 & 23 \\
\hline
\end{tabular}

\section{表 4 閉塞部位}

\begin{tabular}{|c|c|c|c|c|}
\hline & 部 & \multicolumn{2}{|c|}{ 位 } & 症 例 数 \\
\hline 空 & & & 腸 & 11 \\
\hline 回 & & & 腸 & 15 \\
\hline 盲 & & & 腸 & 2 \\
\hline 上 & 行 & 結 & 腸 & 4 \\
\hline 横 & 行 & 結 & 腸 & 5 \\
\hline 下 & 行 & 結 & 腸 & 1 \\
\hline $\mathrm{S}$ & 状 & 結 & 腸 & 9 \\
\hline 直 & & & 腸 & 9 \\
\hline & & & & 56 \\
\hline
\end{tabular}

表 5 術後イレウス既往手術

\begin{tabular}{|c|c|}
\hline 手術 & 症 例 数 \\
\hline 虫 垂 切 除 術 & 7 \\
\hline 胃 切 除 術 & 12 \\
\hline イレウス手術 & 2 \\
\hline 直 腸 癌 根 治術 & 1 \\
\hline 結 腸 癌 根 治術 & 1 \\
\hline 胃穿孔ドレナージ & 1 \\
\hline $\mathrm{S}$ 状結腸切除術 & 1 \\
\hline 小腸部分切除術 & 1 \\
\hline 詳 細 不 明 & 1 \\
\hline 計 & 27 \\
\hline
\end{tabular}

表 7 高踰者イレウス手術症例原因別分類

\begin{tabular}{|c|c|c|c|}
\hline & 分 & 症例数 & 小計 \\
\hline $\begin{array}{l}\text { 良 } \\
\text { 性 }\end{array}$ & $\begin{array}{l}\text { 癒 着 性 } \\
\text { 軸転 不通症 } \\
\text { 腸 結節形成症 } \\
\text { 嵌頓ヘルニア }\end{array}$ & $\begin{array}{l}3 \\
3 \\
1 \\
4\end{array}$ & $\begin{array}{c}11 \\
(43.3 \%)\end{array}$ \\
\hline $\begin{array}{l}\text { 悪 } \\
\text { 性 }\end{array}$ & $\begin{array}{l}\text { 癌性イレウス } \\
\text { 癌再発性イレウス } \\
\text { 癌腫による腸重積 }\end{array}$ & $\begin{array}{r}10 \\
4 \\
1\end{array}$ & $\begin{array}{c}15 \\
(57.7 \%)\end{array}$ \\
\hline & 計 & 26 & \\
\hline
\end{tabular}

表 2 同年齢別分布

\begin{tabular}{|c|c|c|}
\hline 年 齢 & 症例数 & 小 計 \\
\hline $0 \sim 9 才$ & 1 & \\
$10 \sim 19 才$ & 3 & \\
$20 \sim 29 才$ & 0 & 30 \\
$30 \sim 39 才$ & 2 & $(53.6 \%)$ \\
$40 \sim 49 才$ & 7 & \\
$50 \sim 59 才$ & 11 & \\
$60 \sim 69 才$ & 6 & \\
\hline \hline $70 \sim 79 才$ & 19 & \multirow{2}{*}{26} \\
$80 \sim 89 才$ & 5 & $(46.4 \%)$ \\
90 オ上 & 2 & \\
\hline 計 & 56 & \\
\hline
\end{tabular}

表 3 発生原因別分類

\begin{tabular}{|c|c|c|c|}
\hline & 類 & 症例数 & 小計 \\
\hline 単 & 㾙 着 性 & 8 & 37 \\
\hline 純 & 腫 瘍 性 & 27 & \\
\hline 性 & 異 物 性 & 2 & $(00.1 \%)$ \\
\hline & 絞 扼 性 & 4 & \\
\hline 複 & 軸転不通症 & 9 & \\
\hline 雑 & 腸 重 積 症 & 1 & \\
\hline 性 & 腸結節形成症 & 1 & \\
\hline & 嵌頓ヘルニア & 4 & \\
\hline & 計 & 56 & \\
\hline
\end{tabular}

表 6 高齢者イレウス手術症例一覧表

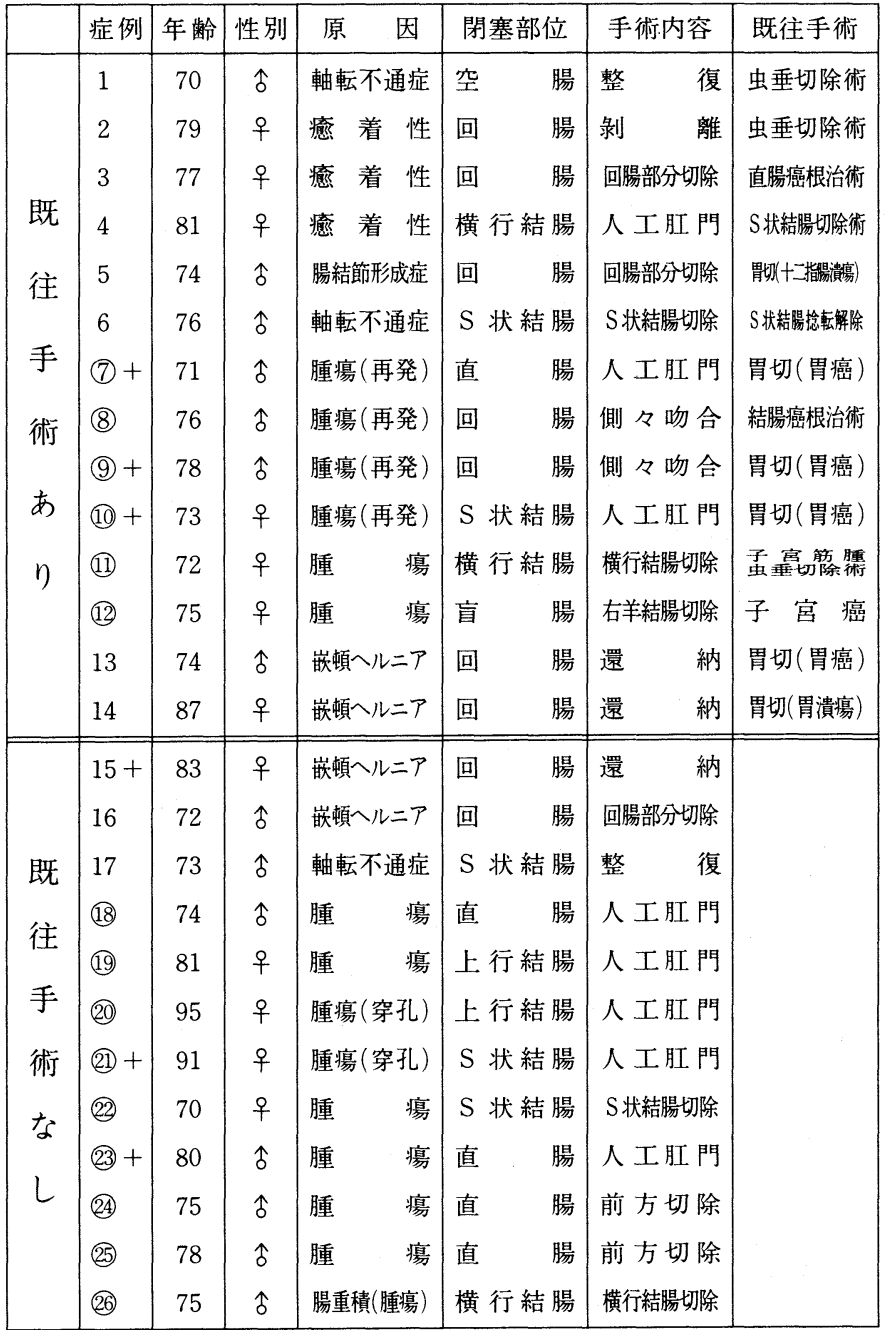

○: 悪性 + 


\section{1 才の絞扼性イレウス患者の看護}

\section{一多くの合併症に難渋した事例一}

松本俊子, 飯島隆子, 橋本さち子

黒沢のり子, 桜井佐和子

(茨城士浦協同病院外科病棟)

\section{はじめに}

医療技術の発達により, 外科手術の高龄化が進んでいる。高齡者は, 症 状の出現が遅いため, 重篤状態に陥ってからの手術あまれではない。今回 術前寝たきりで, 全身衰弱が著しい8 81 オ緊急手術後の看護を経験した。 術後さまざまな合併症を併発したが，３ヶ月後，車椅子退院を果した。乙 の症例で経験した, 衰弱の激しい老人が術後陥り易い問題点と, その看護 の具体策について, 検討したので報告する。

\section{事例紹介}

患者 81 才女性

入院 S 61 年 12 月 12 日

S 62 年 3 月 9 日

病名絞把性イレウス

手術 $260 \mathrm{~cm}$ 回腸盲腸切除 小腸結腸端側吻合

既往 S 55 年胃癌飞て累切 S 58 年肺結核

前術体重 $29 \mathrm{~kg}$

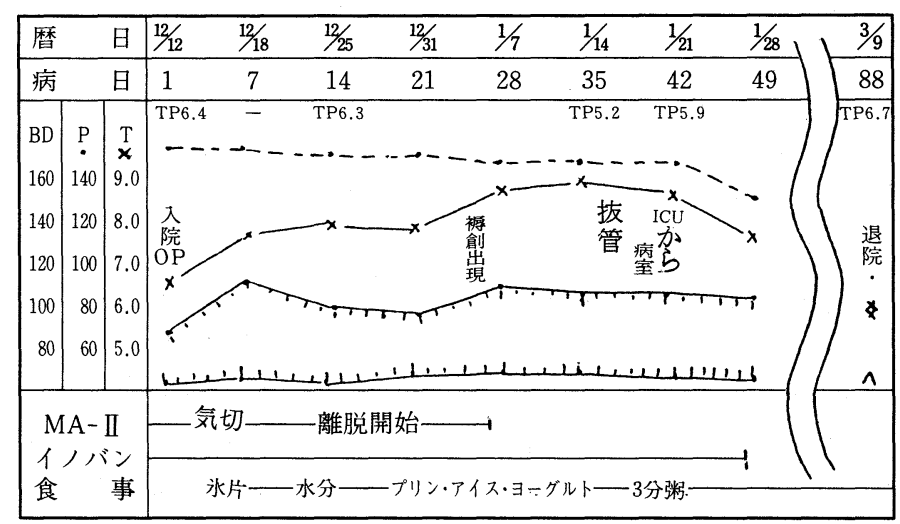

\section{問 題点}

(1)呼吸不全 (2)血圧低下 (3)栄養不良 (4) 裖創 (5) 排尿障害 (6) ボケ症状

看護の実際

(1) 呼吸不全

術当日より，挿管にて M A - II 装着した。術後 2 日目に，呼名反応が 現れたため抜管を試みたが, 呼吸状態が悪く, 術後6日目に, 気管切開を した。術後 14 日目より, M A - II 離脱を開始するが, 設定を変更するたび に, 呼吸困難, 無呼吸になり, 目が離せない状態が続いた。患者の呼吸状 態を確認しながら深呼吸を促し,「吸って, はいて」と声をかけ, 自発呼 吸をするように励した。定期的に血液ガスを測定をし，MAーIIの設定を 変更, 術後28日に離脱した。離脱に時間はかかったが, 心配していた呼吸 器合併症は併発せずにすんだ。

(2) 血圧低下

術前から，イノバンの持続点滴をした。検温時，寝衣交換など体動時に 血圧チェックをした。イノバンを切る時も慎重に, 48 時間に 1 滴ずつ減ら して，術後49日目に中止となった。 


\section{(3) 栄養不良}

経口摂取が満足にできないため，IV H ルよる持続点滴を長期に行った。 食事の際は,できるだけ坐位とし，安楽な体位をとった。家人ととあに， 好物のおむ湯をスプーンで一ロずっ, 時間をかけて励しながら摂取させた。 退院時には，3分粥を $1 / 4$ 程摂取できるようになった。

\section{(4) 裖 創}

栄養低下, 自力にて体交不能, M A - II 装着時同一体位になりやすく, 術前より全身拘縮・るいそう著明なため, 局所への圧迏がさけられず, 広 範囲の裖創ができた。特に両殿部, 仙骨部は潰瘍化し, 浸出液が多量にみ られ, 微熱も続いた。乙れには, 無圧布団の利用, 3 時間毎の体交に加え て, イソジンシュガーの使用が効果をむたらした。1日 1 回の包交で, 使 用して 4 日目より, 創の表面が渴きはじめ, 外側から新しい皮膚が形成さ れた。退院時には, ひどかった仙骨部と殿部の一部を残して治瘉した。

(5) 排尿障害

正確な尿量を得, 尿路感染・褯創悪化防止のため, 退院時までバルンを 留置した。膀洗により尿路感染は妨げたが, 挿入部からの尿あれはひどく

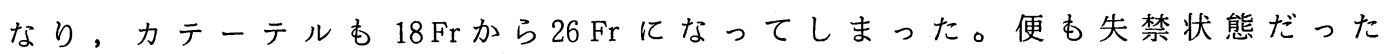
ために, あえてバルン抜法の方向にはあっていけなかった。

(6) ボケ症状

意識が回復してからも，看護婦と家人の見分けがつかない, どてにいる のかがわからないなど見当識障害がみられた。又, 体交・包交など処置に ついても大きな恐怖感をもっており，何度説明しても「やらないでくれ， 助けてくれ」の言葉が返ってきた。しかし, 患者が苦痛を伴う看護行為で はあったが, 必要な処置なので, わかりやすく説明して, 励しながら行っ た。その結果, I V H ドレーン類の自己抜去等の事故は防止できた。

考察

本症例が, 術後併発した問題点の原因は, 2 つると考えられる。第一 に, 緊急手術のため十分な検查ができず, 術前の状態が把握できなかった。 又, 寝たきりで体力が低下しているうえに，ショックに陥ってからの手術 であった。第二に，ICUでの1ケ月間は，生命維持に集中したため，患 者と心の通う会話が扔ろそかになりがちであり, ボケ症状の誘因になった と思われる。そして，看護上困難だった点は， M A - II 離脱をはじめとす る処置に打いて, 本当に苦痛があるの心, 恐怖心からなのか真意がっかめ ない事であった。又, 本症例は, どてまでを回復とみたらょいのか判断し にくかったので, 看護者側に戸惑いがあった。てれらの問題解決には, 患 者の安楽を第一に考え, そのうえで, 術前の患者の状態を理解し, これに 少しであ近づくという方向で看護にあたった。本症例から, 高齢者に特有 な看護のあり方を学ぶ事ができたので, 今後の老人看護に, 役立ててゆき たい。 
○柴田隆, 松岡富男, 赤石隆, 遠藤義洋, 濱田千枝, 斎藤礼次郎, 寺島 秀夫, 菅谷虎

（秋田県厚生連 平鹿総合病院 外科）

昭和 51 年から 60 年までの 10 年間に, 当院外科で手術を施行した大腸癌によるイレウス症例 32 例について検討した。同期間の大腸癌全手術例数は 249 例で, 頻度は $12.9 \%$ あった。部位別 では下行結腸の頻度が $22 \%$ と高かった。Stage別ではIVが $23 \%, V か ゙ 42 \%$ と進行例が多く, 切 除率は $81 \%$, 治癒切除率は $50 \%$ と低かった。腫瘍は全周性のものが77\%を占め，4例は口側に 穿孔を合併していた。術後合併症もショック，急性腎不全などの重篤なむのが多かった。 5 生 率は $27 \%$ と低率であったが, 治癒切除例に限れば $67 \%$ と良好であった。

\section{表 1. 大腸癌イレウス手術症例（昭51６0） \\ A)

\begin{tabular}{|c|c|c|}
\hline & 全大腸癌手術症例 & 大腸癌イレウス手術症例 \\
\hline 例 & 249 例 $\left[\begin{array}{ll}\text { 結腸癌 } & 136 \\
\text { 直腸癌 } & 113\end{array}\right.$ & 32 例 $\left[\begin{array}{ll}\text { 結腸癌 } & 19 \\
\text { 直腸癌 } & 13\end{array}\right.$ \\
\hline 平均年齢 & $\begin{array}{c}62.7 \text { 才 } \\
(26 \sim 89 \text { 才) }\end{array}$ & $\begin{array}{c}64.7 \text { 才 } \\
((33 \sim 83 \text { 才 })\end{array}$ \\
\hline $\begin{array}{l}\text { 性 比 } \\
\text { (男: 女) }\end{array}$ & $120: 129$ & $18: 14$ \\
\hline
\end{tabular}

B）全大腸癌に占めるイレウス合併頻度 $12.9 \%$

表 2. 症状と病悩期間

A) 症 状

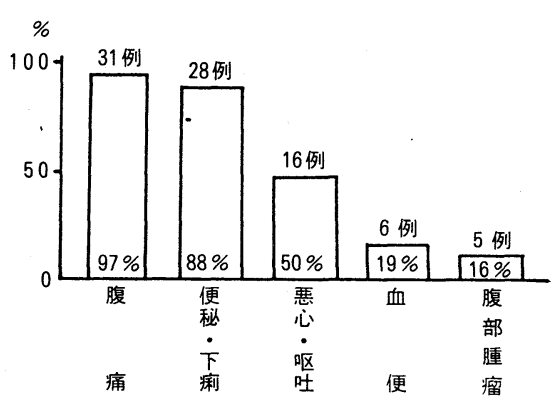

B) 病悩期間

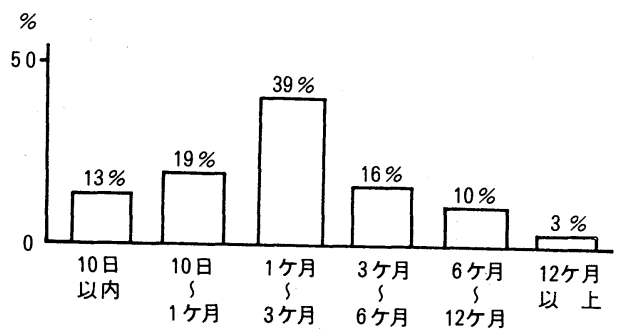

図1.手術までの経過

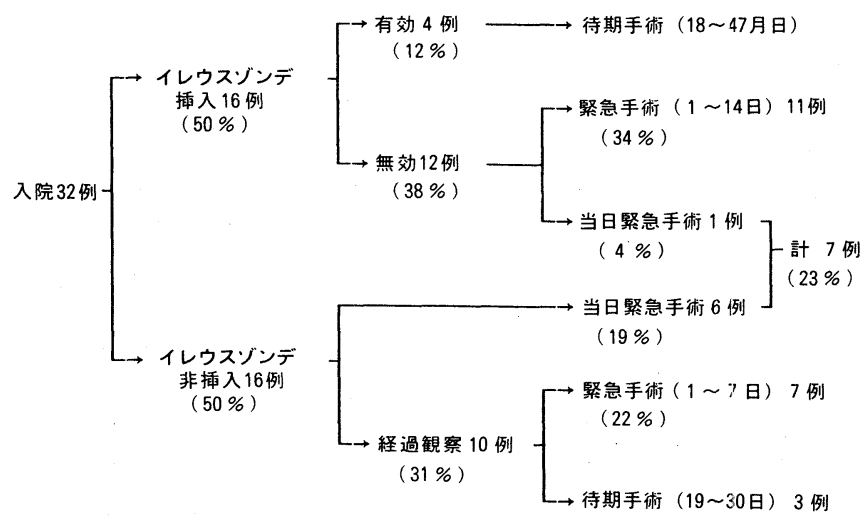

図2. 腫瘍占拠部位

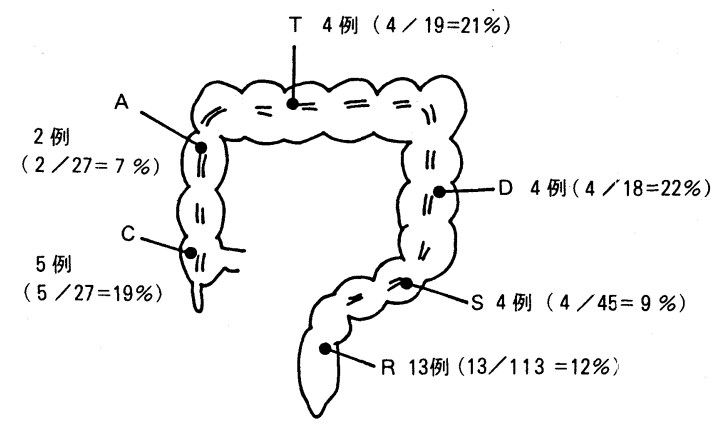


表 3. $\mathrm{st}$ a g e 分類

\begin{tabular}{c|c|c} 
Stage & \multicolumn{1}{|l|}{ イレウス症例 } & 全大腸癌手術症例 \\
\hline I & 1 例 $(3.2 \%)$ & 16 例 $(6.6 \%)$ \\
II & 3 例 $(9.7 \%)$ & 59 例 $(24.3 \%)$ \\
III & 7 例 $(22.6 \%)$ & 52 例 $(21.4 \%)$ \\
IV & 7 例 $(22.6 \%)$ & 63 例 $(25.9 \%)$ \\
V & 13 例 $(41.9 \%)$ & 53 例 $(21.8 \%)$ \\
\hline 計 & 31 例 $(100.0 \%)$ & 243 例 $(100.0 \%)$
\end{tabular}

表5. 手術術式

A) (1) 切除例 26 例

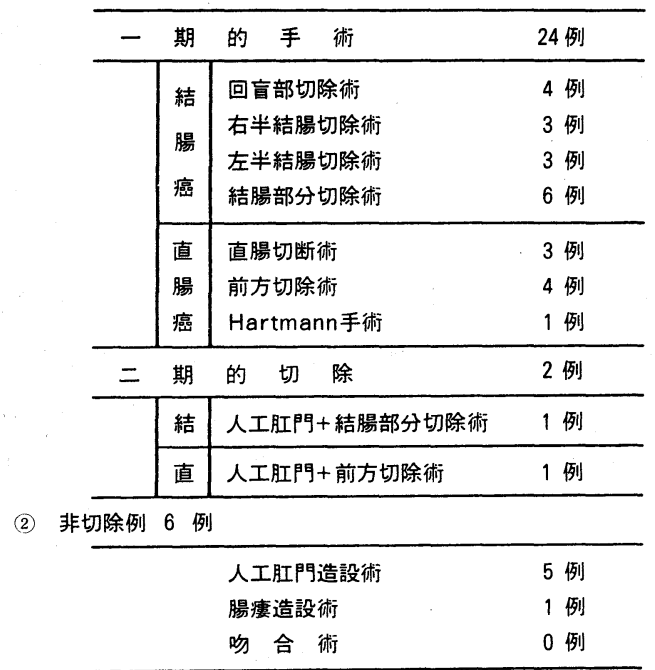

B ）大腸癌イレウス切除率 $81 \%$ 大腸癌イレウス治瘾切除率 $50 \%$ 全大腸癌治瘾切除率 $\quad 80 \%$

表 8. 術後合併症

$\begin{array}{ll}\text { ショック } & 3 \text { 例 }(9.4 \%) \\ \text { 急性腎不全 } & 2 \text { 例 }(6.3 \%) \\ \text { 肺 炎 } & 2 \text { 例 }(6.3 \%) \\ \text { イレゥス } & 2 \text { 例 }(6.3 \%) \\ \text { 呼吸不全 } & 1 \text { 例 }(3.1 \%) \\ \text { 縫 合不全 } & 1 \text { 例 }(3.1 \%) \\ \text { 急性心筋梗塞 } & 1 \text { 例 }(3.1 \%) \\ \text { 急性硬膜下血腫 (原因不明) } & 1 \text { 例 }(3.1 \%)\end{array}$

表 4. Duke s 分類

\begin{tabular}{ccc} 
Dukes & A & 1 例 $(3.8 \%)$ \\
B & 3 例 $(11.5 \%)$ \\
C & 22 例 $(84.6 \%)$ \\
\hline 計 & 26 例 $(100.0 \%)$
\end{tabular}

表6. 切除標本 の検討

A) 腫瘍の肉眼分類

$\begin{array}{lrl}0 \text { 型 (表在型) } & 0 \text { 例 } & (0 \% \%) \\ 1 \text { 型 }(\text { 腫瘤型) } & 1 \text { 例 } & (3.8 \%) \\ 2 \text { 型 (限局潰痬型) } & 18 \text { 例 } & (69.2 \%) \\ 3 \text { 型 (浸潤潰痬型) } & 6 \text { 例 } & (23.1 \%) \\ 4 \text { 型 (びまん浸潤型) } & 1 \text { 例 } & (3.8 \%) \\ 5 \text { 型 (特殊型) } & 0 \text { 例 } & (0 \% \%)\end{array}$

B ）腫瘍の腸管環周に占める割合

$\begin{array}{lrl}0 \sim 1 / 2 \text { 周 } & 1 \text { 例 } & (3.8 \%) \\ 1 / 2 \text { 周 悪全周性 } & 5 \text { 例 } & (19.2 \%) \\ \text { 全周性 } & 20 \text { 例 } & (76.9 \%) \\ & 4 \text { 例 } & (12.5 \%)\end{array}$

表7. イレゥスの病態

$\begin{array}{ll}\text { 腫瘍による管腔狭窄 } & 29 \text { 例 }(90.6 \%) \\ \text { 腸重積 (腫瘍先進) } & 1 \text { 例 }(3.1 \%) \\ \text { 小腸狭窄 (小腸への浸潤) } & 1 \text { 例 }(3.1 \%) \\ \text { 腫瘍近傍の索状物による回腸捻転 } & 1 \text { 例 }(3.1 \%)\end{array}$

表 9. 予後

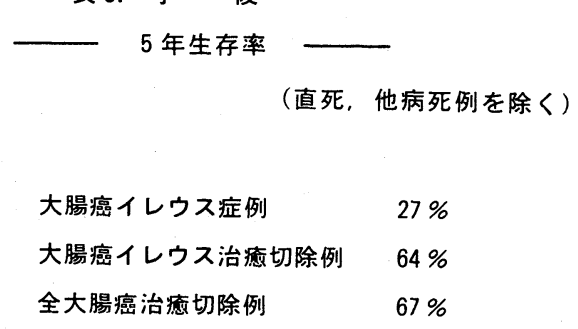

\section{（最後に）}

当院では大腸癌イレウス症例に対して一期的切除を原則としているが，IV Hなどの患者管 理の発達した現在む術後合併症は高率であり, 患者の全身状態や術中の局所所見より適宜，二 期的切除法を選択すべきであると考える。 